Ulil norden

\title{
Aktivera natur och kulturarv
}

- för hållbar utveckling och tillväxt

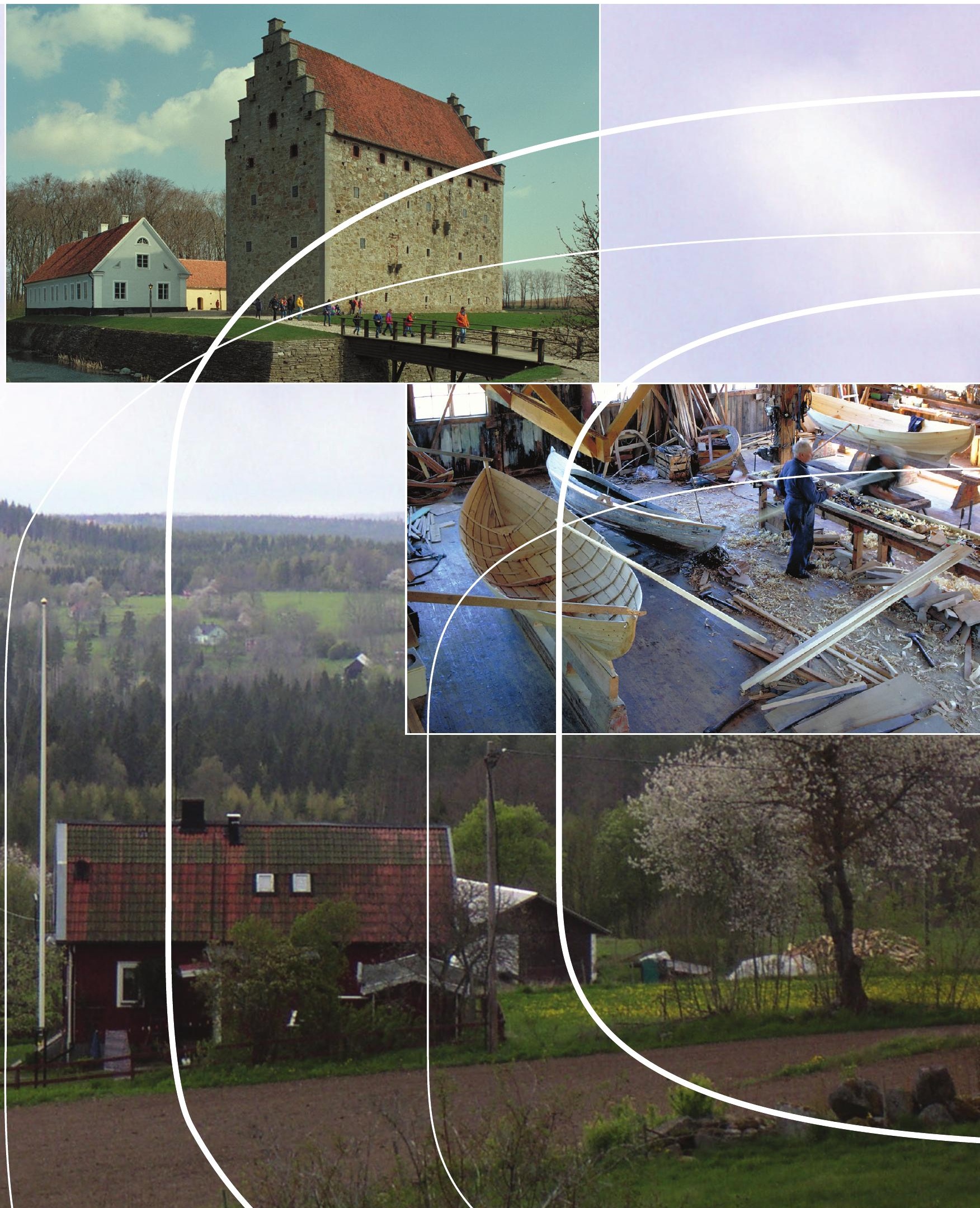



enorden 



\section{Aktivera natur och kulturarv \\ - för hållbar utveckling och tillväxt}

Daniel Nilsson och nordisk projektgrupp

TemaNord 2011:526 
Aktivera natur och kulturarv

- för hållbar utveckling och tillväxt

TemaNord 2011:526

ISBN 978-92-893-2220-1

(C) Nordiska ministerrådet, Köpenhamn 2011

Tryck: Kailow Express ApS

Upplaga: 700

Omslagsfoto: Pål-Nils Nilsson, Hans Antonsson

Foto: John Bjarne Jordal, Jan Augustsson, Daniel Nilsson, Ingvar Jundén, Ole Akhøj,

Ann Mari Westerlind, Haldor Tuvin, Morten Stenak, Árni Geirsson, Louise Straarup

Nataliya Hulusjö, Marie Lier, Islands Turistråd, Thor Andersen, Guðbjörg Gunnarsdóttir

Helgi Michelsen, Bengt A. Lundberg och Sven-Erik Magnusson

Printed in Denmark

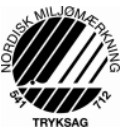

Denna rapport är utgiven av med finansiellt stöd från Nordiska ministerrådet. Innehållet i rapporten avspeglar inte nödvändigtvis Nordiska ministerrådets synpunkter, åsikter eller anbefallningar.

www.norden.org/publikationer

\section{Natur \& \\ Kulturarv}

\section{Det nordiska samarbetet}

Det nordiska samarbetet är ett av världens mest omfattande regionala samarbeten. Det omfattar Danmark, Finland, Island, Norge och Sverige samt Färöarna, Grönland och Åland.

Det nordiska samarbetet är politiskt, ekonomiskt och kulturellt förankrat och är en viktig partner i europeiskt och internationellt samarbete. Den nordiska gemenskapen arbetar för ett starkt Norden i ett starkt Europa.

Det nordiska samarbetet vill styrka nordiska och regionala intressen och värderingar i en global omvärld. Gemensamma värderingar länderna emellan bidrar till att stärka Nordens ställning som en av världens mest innovativa och konkurrenskraftiga regioner.

Nordiska ministerrådet

Ved Stranden 18

DK-1061 København K

Telefon (+45) 33960200

www.norden.org 


\section{Innehållsförteckning}

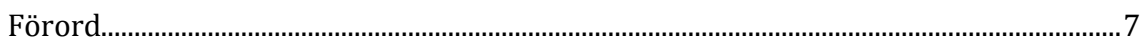

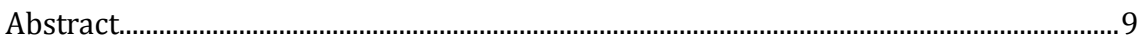

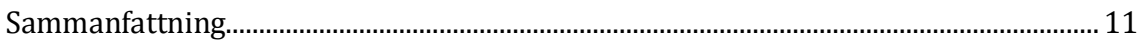

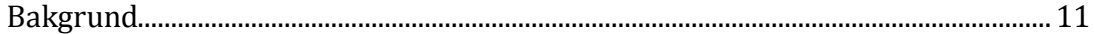

Centrala slutsatser och förslag i sammandrag .......................................................... 12

1. Aktivera natur och kulturarv............................................................................................ 19

1.1 Syfte och målgrupper ................................................................................................. 19

1.2 Rapportens upplägg......................................................................................... 19

2. Projektbakgrund ......................................................................................................... 21

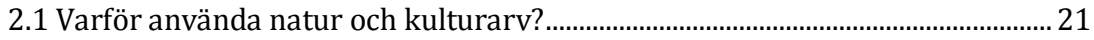

2.2 Mål och avgränsningar................................................................................................ 21

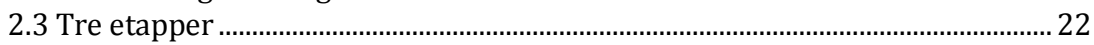

2.4 Teman

2.5 Gemensamma utgångspunkter............................................................................... 23

2.6 Det handlar om hållbart bruk.................................................................................. 24

2.7 Synergier mellan natur och kulturarv................................................................. 25

2.8 Projektets koppling till styrdokument..................................................................... 26

2.9 Deltagare i projektet................................................................................................... 27

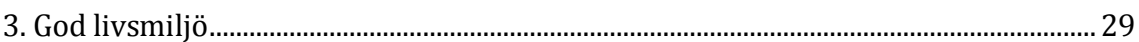

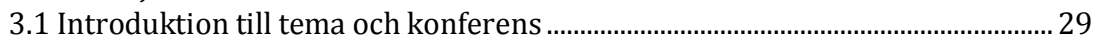

3.2 Konferens - Den goda vardagen............................................................................. 31

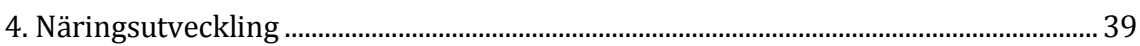

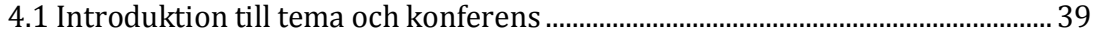

4.2 Konferens - Natur, kulturarv och näringsutveckling ......................................... 40

5. Natur- och kulturarvsturism ...................................................................................... 47

5.1 Introduktion till tema och konferens ..................................................................... 47

5.2 Konferens - Resa, bruka, bevara ……………......................................................... 49

6. Natur- och kulturarvskraft 2010 ..................................................................................... 57

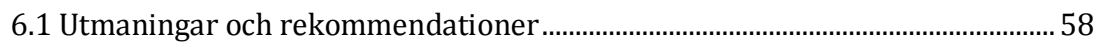

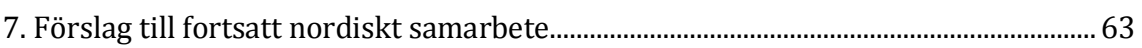

7.1 Projekt - erfarenhetsutbyte mellan nordiska landskap

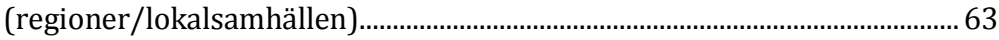

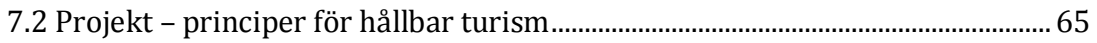

7.3 Projekt - metoder för ekonomisk värdering av natur- och

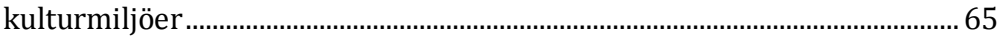

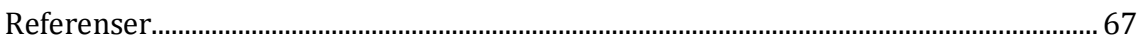

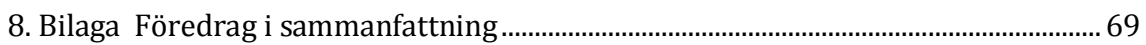

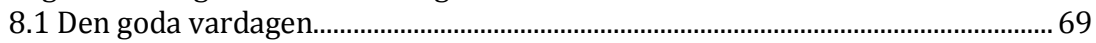

8.2 Natur, kulturarv och näringsutveckling ………................................................. 79

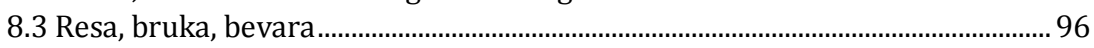

8.4 Natur- och kulturarvskraft...................................................................................111 
Summary...

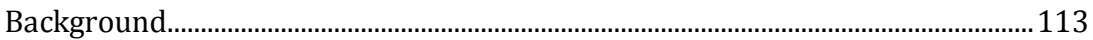

Central conclusions and proposals in summary …...............................................114

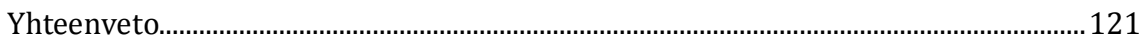

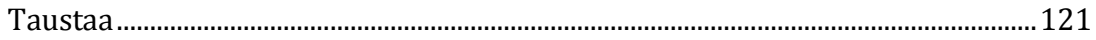

Alla yhteenveto keskeisistä päätelmistä ja ehdotuksista ........................................122

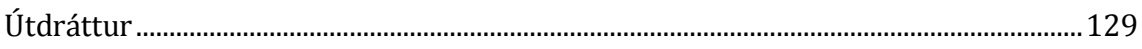

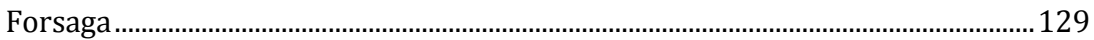

Hér að neðan eru mikilvægar ályktanir og tillögur dregnar saman........................130 


\section{Förord}

Det är först när natur- och kulturvärden blivit förmedlade, gjorts förståeliga och bragd i samspel med människor som de får sina betydelser och mening. Genom att bruka natur och kulturarv som resurser för hållbar utveckling och tillväxt kan värden göras tillgängliga och bli en angelägenhet för fler människor. Det kan bidra till bättre måluppfyllelse för kultur-, miljö-, näring och friluftspolitik och andra politikområden. Det är uppenbart att arbetet med natur och kulturarv som komponenter för utveckling och tillväxt i högsta grad är en gemensam angelägenhet för många aktörer För att integrera natur och kulturarv i utvecklings- och tillväxtprocesser är det därför centralt att frågorna kopplas till politiska beslutsprocesser.

Hållbar utveckling handlar såväl om framtid som om nutid och dåtid. Samspelet mellan natur och människa har yttrat sig på olika sätt och därför skiftat genom historien på grund av olika behov, kunskap, ekonomi och ideologier. Det som tidigare betecknades som hållbart har i flera fall visat sig vara ohållbart. Det som många numera definierar som lösningar på dagens problem kommer med stor säkerhet att framträda som morgondagens bekymmer. Det är därför viktigt att det finns en levande diskussion, baserat på en generell kunskapsgrund, om vilka lösningar som är hållbara i olika platsspecifika situationer. Det finns mycket att lära av att se hur andra har gått tillväga.

Denna rapport presentar resultat från projektet Natur och kulturarv som resurs för hållbar utveckling och tillväxt. I projektet har både naturoch kulturarvsmyndigheter i de nordiska länderna varit representerade. Genom stödet från Nordiska ministerrådet har tillfälle getts till nätverksbyggande och erfarenhetsutbyte. De konferenser som projektet har anordnat har haft en bred nordisk spridning vad gäller deltagande från olika aktörer som arbetar med natur och kulturarv som utvecklings- och tillväxtfaktorer. Projektet vill tacka föredragshållare och deltagare som delat med sig av sina erfarenheter och kunskaper vid dessa arrangemang.

Jostein Løvdal, ordförande
Daniel Nilsson

huvudsekreterare 



\section{Abstract}

This report presents the results of the project Natural and cultural heritage as a resource for sustainable development and growth financed by the Nordic Council of Ministers. Both natural and cultural heritage authorities in the Nordic countries have been represented in the project.

The examples discussed at the four conferences arranged by the project show many opportunities and approaches how natural and cultural heritage can function as resources for sustainable development and growth. Some central experiences and fundamental prerequisites for creating a sustainable development force have been identified. These require a balance being created between financial, social, cultural and environmental effects. The project also considers that cooperation in general needs to be developed between the policy areas affected and the various actor levels within the Nordic countries. Natural and cultural heritage authorities can increasingly be partners within growth policy. Central government should assume overall responsibility for sector coordination and encourage and arrange cross-sector meeting places. It is also very important that municipalities integrate natural and cultural heritage in their growth and development work. The project recommends national cross-sector government mandates being developed to increase the col-laboration between operators within natural and cultural heritage and operators within development and growth.

There is a need for more collaboration between public, private, civil and academic actors in the form of e.g. partnerships. Models for how central government, municipalities and commercial operators can finance the preservation of natural and cultural heritage as a foundation and infrastructure for business need further investigation. Continued dissemination of knowledge and good examples of how natural and cultural heritage can contribute to sustainable development and growth is important. Existing research and available analyses from this field of development should therefore also be summarised and disseminated.

Proposals for further Nordic cooperation projects are:

- exchange of experiences and analysis of best practice between Nordic landscapes (regions/local communities) who use natural and cultural heritage purposefully for development and growth

- collaboration on principles for sustainable tourism

- analysis and testing of methods for economic evaluation of natural and cultural environments 



\section{Sammanfattning}

Det nordiska projektet Natur och kulturarv som resurs för hållbar utveckling föreslår att:

- nationella tvärsektoriella regeringsuppdrag utformas för att stärka samverkan mellan natur- och kulturarvsaktörer och utvecklings- och tillväxtsaktörer

- natur- och kulturarvsmyndigheter skapar mötesplatser för att utveckla dialogen med nationella, regionala och lokala aktörer som arbetar med utvecklings- och tillväxtfrågor.

- det utreds modeller för hur staten, kommuner och kommersiella aktörer kan finansiera bevarande av natur och kulturarv som bas och infrastruktur för näringsliv.

- natur- och kulturarvsmyndigheter initierar fler samarbeten mellan offentliga, privata, civila och akademiska aktörer i form av t.ex. partnerskap.

Förslag till nordiska uppföljningsprojekt handlar om:

- erfarenhetsutbyte och analys av bäst praktik mellan nordiska landskap (regioner/lokalsamhällen) som tar natur och kulturarv målmedvetet i bruk för utveckling och tillväxt

- samarbete om principer för hållbar turism

- analys och test av metoder för ekonomisk värdering av natur- och kulturmiljöer

\section{Bakgrund}

Projektet Natur och kulturarv som resurs för hållbar utveckling och tillväxt startade sommaren 2008 med finansiering från Nordiska ministerrådet. Det bygger på samverkan mellan natur- och kulturarvsmyndigheter och alla nordiska länder är representerade, inklusive Färöarna. Projektet inleddes med en kartläggning av hur de olika länderna arbetar med natur och kulturarv som faktorer för utveckling och tillväxt (TemaNord 2009:513). I den påföljande fasen av projektet genomfördes tre tematiska konferenser med fokus på God livsmiljö, Näringsutveckling och Natur- och kulturarvsturism. Som en del i den avslutande etappen genomfördes en workshop, Natur- och kulturarvskraft 2010, som återkopplade till resultaten från konferenserna och utifrån dessa diskuterade möjliga handlingsvägar framåt. Projektet har varit inriktat på de 
mervärden som natur och kulturarv kan bidra med för hållbar utveckling och tillväxt. Målen med projektet har varit att:

- Synliggöra natur och kulturarv som faktorer för utveckling och tillväxt

- Stärka samverkan mellan berörda politikområden och aktörer på nationell och nordisk nivå

- Visa hur natur och kulturarv kan integreras i utvecklings- och tillväxtprocesser

- Ge förslag till åtgärder och fortsatt arbete

\section{Centrala slutsatser och förslag i sammandrag}

\section{Natur- och kulturarv kan bidra till utveckling och tillväxt}

Natur och kulturarv är utvecklingsresurser, både materiellt och immateriellt. De är källor till kunskap som ger upplevelse, nyfikenhet och perspektiv. Detta utgör en viktigt grund för nytänkande, innovation och vidareutveckling. Natur och kulturarv är ett uttryck för vad platserna har varit, vad de är och vad de kan bli. Genom studier och förmedling av natur och kulturarv blir platsens resurser och förutsättningar synliggjorda, både ur historiskt och i ett utvecklingsperspektiv.

Det är först när natur- och kulturarvsvärden är synliggjorda som de kan användas strategiskt i värdeskapande syfte. Det finns samband mellan ekologiskt, socialt, kulturellt och ekonomiskt värdeskapande. En förutsättning för hållbar utveckling är därför att natur, kulturarv och andra intressen ses som varandras resurser.

... och bruket av natur- och kulturarvsvärden ska vara hållbart

De som använder natur och kulturarv behöver se till en hållbar förvaltning samtidigt som natur- och kulturarvsföreträdare behöver se användarnas behov. I förhandlingar mellan olika intressen behöver vi söka efter lösningar baserat på såväl generell kunskap om hållbarhet som platsspecifika förutsättningar. Det handlar om att ha insikt i sammanhangen och tänka och agera utifrån både ett lokalt och globalt perspektiv.

\section{Natur- och kulturarvsmyndigheter har en viktig roll att spela tillsammans...}

Samarbete mellan natur- och kulturarvsmyndigheter ger bättre förutsättningar för att vara drivande i frågor om ökad livskvalitet och hållbar tillväxt. Om myndigheterna uppträder som en part utåt kan detta bidra till att en ökad tydlighet och att budskapen får en ökad tyngd. Myndigheterna kan också ge bättre service till alla andra aktörer, t.ex. genom att erbjuda gemensam kunskap och information. 


\section{... och de måste spela ihop med andra intressen}

Det är ofta andra faktorer än natur och kulturarv som betraktas som viktiga när det gäller regional och lokal utveckling och tillväxt. Det är avgörande att natur och kulturarv inkluderas med andra intressen på nationell, regional och lokal nivå. Det är viktigt att skilda perspektiv bryts och vägs mot varandra samtidigt som det sker ett erfarenhetsutbyte och lärande som kan föra utvecklingen framåt. För att natur och kulturarv ska kunna vara en kraft för hållbar utveckling och tillväxt krävs med andra ord ett samspel mellan berörda aktörer och en växelverkan mellan strategisk och praktisk nivå.

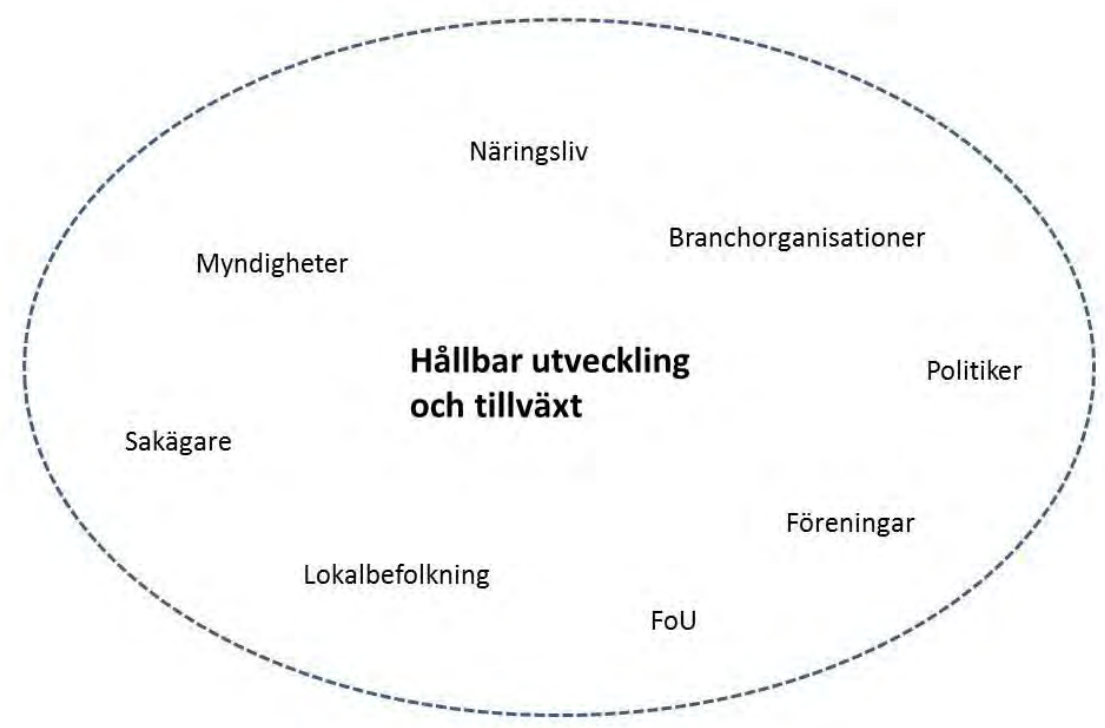

Samverkansarenan för natur och kulturarv i hållbar utveckling och tillväxt består av en mängd olika aktörer på olika samhällsnivåer och inom såväl det offentliga som den privata sfären. Samverkanskonstellation varierar beroende på frågan och dess geografiska hemvist och relevans.

Mötesplatser för sektorsövergripande samverkan bör anordnas på alla samhällsnivåer. För att få till stånd ett samarbete över sektorsgränser räcker ofta inte en god vilja utan det behövs ofta tydliga motiv. Vinsterna med samverkan behöver identifieras inom berörda verksamhetsområden. Det är också viktigt att samarbetet är bundet till någon form av förpliktelse. Den centrala politiska nivån bör därför ge gemensamma uppdrag till myndigheter på nationell och regional nivå för att utveckla arbetet med natur och kulturarv som värdeskapande samhällsresurser. Det är också betydelsefullt att en långsiktig samverkan mellan olika parter formaliseras genom t.ex. samarbetsavtal, partnerskap, gemensamma handlingsplaner eller gemensamt finansierade program som löper över längre tidsperioder.

\section{Skapa ramverk som stödjer regionala och lokala initiativ...}

Ett statligt ramverk som underlättar och kan fungera som katalysator för lokala satsningar och initiativ kräver bättre samordnade sektorsintres- 
sen avseende mål, styrmedel och åtgärder samt en tydlig och klar ansvarsfördelning mellan aktörerna. För detta syfte kan det finnas behov av att staten identifierar och analyserar faktorer som underlättar respektive försvårar tvärsektoriell koordinering. Statliga initiativ kan vara en viktig drivkraft för att sätta igång nya projekt och verksamheter på regional och lokal nivå. Sådana initiativ bör följas upp för att kunna säkra kompetensutveckling och erfarenhetsspridning.

\section{... och utveckla dialog som arbetsmetod}

För att ta tillvara engagemang och kunskap i lokalsamhället behöver staten, i ökad utsträckning, vara dialogpartner och medaktör i regionala och kommunala utvecklingsprocesser. Statliga förvaltningar behöver kompetens och verktyg för att länka samman aktörer och fungera som bro mellan övergripande strategisk nivå och lokal praktisk nivå.

\section{Integrera natur och kulturarv i kommunalt utvecklingsarbete...}

Många kommuner startar projekt för att sätta natur och kulturarv på den politiska dagordningen och mer genomgripande införliva frågorna i utvecklingsarbete och planprocesser. De centrala verken bör i detta sammanhang följa, analysera och sprida kunskap kring kommunalt, mellankommunalt och regionalt utvecklingsarbete.

Samverkan mellan sektorsförvaltningar, inklusive kulturarvs- och naturvårdskompetenserna, är avgörande för få ett helhetsperspektiv på frågorna. Genom att använda natur och kulturarv som viktiga samhällsresurser skapas medvetenhet om och förhållningssätt till dessa värden och deras betydelser för livskvalitet och lokal utveckling. Inte minst är det viktigt att beakta värdet av tätortsnära natur- och kulturmiljöer. De är centrala för rekreation och friluftsliv och därmed för människors hälsa. Även små grönytor kan vara värdefulla platser för barn och skolverksamhet.

Det finns goda exempel på hur natur och kulturarv använts strategiskt som drivkraft i stads- eller områdesförnyelse. Natur och kulturarv är nära förknippade med lokal identitet och kan bidra till att platser upplevs som mer intressanta och attraktiva och därigenom ge upphov till utveckling $\mathrm{i}$ form av till exempel inflyttning, arbetstillfällen och förbättrad livskvalitet.

\section{... och involvera medborgarna}

Kommunerna har en viktig roll för att hålla ihop den lokala demokratiarenan. Det är grundläggande att lokalbefolkningen deltar i utvecklingen av sin omgivning och att deras kunskaper och erfarenheter tas tillvara, samtidigt som det är viktigt att betona vikten av en professionell yrkesutövning i utvecklingsarbetet. Erfarenheter visar att projekt som bygger på medborgardelaktighet blir mer robusta och framgångsrika över tid.

\section{Skapa förutsättningar för hållbar näringsutveckling...}

Natur- och kulturmiljöer, men även natur- och kulturarvsinformation kan betraktas som infrastruktur för ekonomisk utveckling. Stat och 
kommuner är i egenskap av myndigheter och fastighetsägare viktiga aktörer för att tillgängliggöra natur och kulturarv. Speciellt attraktiva, sett ur ett näringslivsperspektiv, är ofta skyddade miljöer. I många fall finns det möjlighet att, genom utvecklade strategier, planer och föreskrifter, skapa förutsättningar för hållbara verksamheter och ökad sysselsättning i och i anslutning till dessa områden. Samtidigt ökar detta också anspråken på de aktörer som nyttjar resursen att återföra inkomster till lokalsamhället och miljöer som brukas av allmänheten. Modeller för finansiering av kollektiva nyttor, t.ex. i form av skötsel och underhåll av natur och kulturarv, behöver utredas.

Nationella natur- och kulturarvsmyndigheter bör tillsammans med myndigheter och branschorganisationer i näringslivet vidta åtgärder för kompetensutveckling om natur- och kulturvärdens betydelse för hållbar näringsutveckling. Goda exempel bör spridas som kan ge upphov till inspiration och lärande för verksamheter på natur- och kulturarvsgrund. Innovativa miljöer över sektors-, lands- och länsgränser bör stimuleras.

\section{...i samspel mellan det privata och offentliga}

Efterfrågan styr marknaden. Det betyder att expertperspektiv som ofta har varit rådande när det gäller förvaltningen av natur och kulturarv behöver kompletteras med ett brukar- och kundorienterat arbetssätt. Samtidigt är det behov att stärka mekanismerna som gör att marknaden kan understödja en hållbar utveckling.

Förpliktande avtal och partnerskap mellan både näringsliv, myndigheter, forskningsmiljöer och frivillig sektor kan ge ömsesidigt utbyte mellan aktörerna. Natur- och kulturarvsmyndigheterna bör tillsammans med andra myndigheter överväga att engagera sig i sådana partnerskap i syfte att utveckla boendemiljöer, destinationer och näringsliv.

Kommersiella verksamheter kräver ofta en relativt snabb avkastning på sina investeringar, medan offentliga aktörer har möjlighet att agera utifrån ett längre tidsperspektiv. Samtidigt är premissen att vinstdrivande verksamheter måste ha lönsamhet för att vara hållbara i ett långsiktigt tidsperspektiv. Centrala framgångsfaktorer för att uppnå detta är t.ex. god marknadsförståelse, ett fungerande samspel med lokalsamhället och hållbart bruk av natur och kulturarv. Dessutom bör statliga initiativ ha längre tidsramar än vad som idag är brukligt för att önskade resultat ska kunna uppnås. Myndigheterna bör eftersträva regelförbättringar som minskar den administrativa bördan för företag som bedriver verksamhet på natur- och kulturarvsgrund.

\section{Skapa god politik för hållbar turism...}

Goda strategier, principer och kvalitetssäkringssystem för hållbar turism har stor betydelse för hur turismnäringen kommer att utvecklas. De nordiska länderna kan lära av varandra vad gäller att tydliggöra vad hållbar turism betyder i praktiken. Turism-, natur- och kulturarvsmyndigheterna bör gå samman om konkreta projekt för att på så sätt kunna 
utveckla samarbetet mellan sig. Det finns behov av certifieringssystem, för såväl destinationer som verksamheter, som ser till samspelet mellan miljö, ekonomi och samhälle. Rätt utformat kan certifiering vara ett redskap för att integrera turismen i en hållbar samhällsutveckling.

\section{... och förena destinations- och lokal samhällsutveckling}

Destinationsutveckling behöver gå hand i hand med hållbar utveckling av lokalsamhällen. Avgörande för detta är att turismen utgår från förutsättningarna på platsen. En annan erfarenhet är att satsningar på stora/starka turismföretag även kan gynna småskaliga verksamheter på destinationen. För att säkra att natur och kulturarv ska vara en bestående och förstärkande faktor för turismutveckling är det centralt att värdena betraktas både som en resurs och produkt.

Hållbar turism kan ge konkurrensfördelar i kampen om kunder gentemot andra resmål. Men detta kräver kompetens. Turistbranschen behöver förstå vad som ska till och agera så att natur- och kulturarvsvärden kan utvecklas som långsiktiga resurser för näringen. Natur- och kulturarvsmyndigheterna behöver å andra sidan utveckla förståelsen för näringens krav till marknadsanpassning och lönsamhet. Avstånden mellan sektormyndigheter, näring och lokal-samhälle behöver kortas ned för att det ska bli en effektiv samverkan med goda resultat.

För att kunna leverera intressanta och fördjupade upplevelser till besökare blir information, guidning och inte minst ett gott värdskap allt viktigare. För att möta upp detta ökande behov bör metoder och former för utbildning och vägledning om lokalt natur och kulturarv ses över och utvecklas.

\section{Kommunicera natur och kulturarv}

Vikten av att utforma förmedlings- och kommunikationsstrategier för att öka kunskapen om natur och kulturarv bör inte underskattas. En bättre anpassning och koordinering av olika myndigheters digitala tjänster och hemsidor kan bidra till en mer samlad, systematisk och målgruppsanpassad information och marknadsföring av natur och kulturarv.

Teknikutvecklingen skapar nya kommunikationsmöjligheter. Inte minst finns en potential att nå enskilda resenärer via Internet, mobiltelefoner och andra kanaler. Det finns också flera exempel på digitala interaktiva verktyg för att aktivera lokalbefolkningens kunskap om deras vardagslandskap och dela platsspecifika berättelser och minnen.

\section{Forska, analysera och följ utvecklingen}

Det finns behov för tvärvetenskaplig forskning kopplat till natur och kulturarvet som resurs för hållbar utveckling och tillväxt. Det handlar bland annat om att fördjupa kunskaper i gränssnittet mellan natur, kulturarv och näringsliv. Nordiska nationella myndigheter bör tillsammans med forskarvärlden ta initiativ till en strategisk sammanfattning av vil- 
ken forskning som har bedrivits, vad den gett för resultat och vilka behov som finns.

Det är viktigt att fånga trender, status och effekter utifrån alla hållbarhetsdimensioner. Alla värden går inte att värdera i ekonomiska termer men har ändå ekonomisk betydelse, på både kort och lång sikt. Index som även fångar kvalitativa värden behöver därför fortsatt utvecklas och uppgraderas i betydelse.

\section{Förslag till fortsatt nordiskt samarbete}

Detta projekt har följande förslag till fortsatt nordiskt projektsamarbete:

- Erfarenhetsutbyte och analys av tillämpade metoder och samverkansmodeller mellan nordiska landskap (regioner/lokalsamhällen) som arbetar framåtblickande med natur och kulturarv som resurs för utveckling och tillväxt. Det handlar om att ge de utvalda områden en nordisk arena för att diskutera viktiga samhällsfrågor relaterat till natur och kulturarv som framtidsresurser samt analysera "best practice" för en samordnad statlig involvering i samhällsutvecklingsprocesser.

- Projekt som syftar till att utarbeta rekommendationer om gemensamma nordiska principer för hållbar turism.

- Se över forskning och metoder om ekonomisk värdering av naturoch kulturmiljöer samt i nästa steg testa jämförbara metoder i de nordiska länderna. 



\section{Aktivera natur och kulturarv}

\subsection{Syfte och målgrupper}

I denna rapport presenteras de viktigaste slutsatserna från projektet $\mathrm{Na}$ tur och kulturarv som en resurs för hållbar utveckling och tillväxt. Genom det arbete som har genomförts och denna rapport vill projektet lägga en grund för det fortsatta arbetet i Norden, dels genom att förmedla erfarenheter inom fältet och dels genom att adressera förslag till åtgärder till natur- och kulturarvsmyndigheter och andra berörda aktörer.

Rapporten riktar sig till myndigheter och organisationer som praktiskt, akademiskt eller politiskt arbetar med kulturarv och natur samt regional utveckling och tillväxt. Dessa är främst:

- de nordiska ländernas natur- och kulturarvsmyndigheter

- myndigheter som arbetar med regional och lokal utveckling och tillväxt

- näringslivets intresseorganisationer och aktörer

- forskning och utveckling (FoU)

- politiker

\subsection{Rapportens upplägg}

Rapporten inleds med en projektbakgrund som redogör för projektets mål, avgränsningar och genomförande. Projektets kopplingar till centrala styrdokument samt några grundläggande perspektiv och principer för arbetet redovisas. Dessutom redovisas några av de synergier som kan uppnås genom ett integrerat perspektiv på natur och kulturarv och ökad samverkan mellan de motsvarande politikområdena. Kapitlet avslutas med en presentation av de personer och myndigheter som deltagit i projektet.

Detta följs av sammanfattningar av de tre nordiska temakonferenser som projektet anordnat; Den goda vardagen, Natur, kulturarv och näringsutveckling och Resa, bruka, bevara. Kopplat till texterna presenteras praktiska exempel hämtade från föredragen på de olika arrangemangen. Varje temadel i rapporten inleds med en "artikel" som förklarar närmare vad temat står för, visar på intressanta ingångar och ger därmed ett sammanhang och en bakgrund till den genomförda konferensen. Därefter redovisas ett urval av det resultat som kom fram på den nordiska workshopen Natur- och kulturarvskraft som projektet arrangerade hösten 2010. 
Baserat på erfarenheter och resultat av projektet "skissas" i denna del av rapporten förslag till nya nordiska samarbetsprojekt.

I bilaga återfinns sammandrag av föredragen från konferenserna. 


\section{Projektbakgrund}

\subsection{Varför använda natur och kulturarv?}

Allt fler aktörer i Norden har förstått potentialen i att använda natur och kulturarv för utveckling och tillväxt. Det ökande intresset avspeglas i såväl politik som praktik.

Natur och kulturarv spelar stor roll för hur människor upplever livskvalitet och välbefinnande. Landskap med läsbara tidsdjup, brukade marker, rikt djurliv, historiska bebyggelsemiljöer och friluftsmöjligheter är exempel på aspekter som har betydelse för människors val av bostadsort. Samtidigt kan natur och kulturarv även ge upphov till företagande och innovationer och fungera som magnet för besökare och som arenor för olika typer av publika evenemang. En kommersiell användning av natur och kulturarv förutsätter bland annat att balanserade avvägningar görs mellan ekonomiska, sociala, kulturella och miljömässiga effekter.

\subsection{Mål och avgränsningar}

Projektets målsättning har varit att belysa naturens och kulturarvets betydelse som faktorer för hållbar utveckling och tillväxt. Genom att lyfta fram exempel på strategier och konkreta initiativ har projektet velat visa hur natur och kulturarv kan integreras i utvecklings- och tillväxtprocesser. Projektet presenterar idéer och ger rekommendationer om hur kulturarvs- och naturmyndigheter kan vidareutveckla arbetet sinsemellan och med andra politikområden. Dessutom skickas signaler som riktar sig till den politiska arenan och forskarvärlden.

Projektet har omfattat såväl stad som landsbygd. Övergripande frågeställningar som har behandlats i projektet är följande:

- Vilka mervärden kan ökad kunskap om natur och kulturarv bidra med i samhällsprocesserna?

- Hur kan natur och kulturarv brukas hållbart för utveckling och tillväxt?

- Vilka är vinsterna med ett samarbete mellan kulturarvs- och natursektorerna?

Natur och kulturarv är resurser utifrån många olika perspektiv och kan vara bas för ett stort antal samhällsaktiviteter. Projektet har intresserat sig för betydelser och upplevelser knutna till landskap, platser och verk- 
samheter samt hur dessa utnyttjas i nordiska utvecklings- och tillväxtsammanhang. Fokus har legat på hur natur och kulturarv analyseras, tolkas, upprätthålls och förändras, både materiellt och immateriellt, när de på ett kreativt och hållbart sätt utnyttjas som resurs för allmän välfärd och privat företagande.

I detta projekt har vi t.ex. inte tagit med välfärdseffekter av väl fungerande ekosystem och de ekonomiska värden som förknippas med biologisk mångfald och ekosystemtjänster (dvs. tjänster som ekosystemen förser oss med, som rent vatten, ren luft, fiskeresurser, etc).

\subsection{Tre etapper}

Projektet startade 2008 och har genomförts i tre etapper.

Etapp I

I den första etappen genomfördes en kartläggning som syftade till att ge en lägesbild av hur länderna arbetar med natur och kulturarv som resurser för regional och lokal utveckling (TemaNord 2009:513). Denna visar bland annat att $\mathrm{i}$ alla de nordiska länderna finns det ett ökande politiskt och praktiskt intresse för att bruka natur och kulturarv för utveckling och tillväxt. Det finns många gemensamma frågor men vad länderna gör konkret varierar.

\section{Etapp II}

Projektet har anordnat tre tematiska konferenser vilka har fungerat som arenor för nordiskt erfarenhetsutbyte och nätverksbyggande. Deras syfte har även varit att få in önskemål och rekommendationer från de medverkande aktörerna om hur arbetet på respektive tema skulle kunna förbättras. Men även att förmedla goda exempel på lokala, regionala och nationella initiativ i de nordiska länderna som belyser natur och kulturarv som en framgångsfaktor för hållbar utveckling och tillväxt. Konferenserna var:

- Den goda vardagen, Køge, Danmark - den 4-5 november 2009

- Natur, kulturarv och näringsutveckling, Åbo, Finland - den 10-11 februari 2010

- Resa, bruka, bevara, Trondheim, Norge - den 6-7 september 2010

Resultat från konferenserna sammanfattas i kapitel 3, 4 och 5.

\section{Etapp III}

I etapp tre följdes projektresultat upp på en avslutande workshop i Stockholm, samt sammanfattas i föreliggande rapport. Ett särskilt fokus riktas i denna etapp mot nyttan av projektet och spridningen av resultaten. 
På www.raa.se/naturochkulturarv finns ytterligare information om projektet, däribland den nordiska översikten, samt föredrag och reportage från konferenserna.

\subsection{Teman}

Arbetet har sorterats in i tre övergripande, och i olika grad överlappande, temaområden:

- Temat God livsmiljö har behandlat naturens och kulturarvets betydelse i relation till vardagslivet. Det handlar om attraktivitet avseende t.ex. inflyttning, boende, identitet, hälsa, välbefinnande, tätorts- och vardagsnära friluftsliv samt socialt kapital och andra sociala aspekter.

- Temat Näringsutveckling behandlade näringar som bärare av kulturarv, natur- och kulturarvsbaserad innovation och utveckling av företag, varumärken, regional profilering och platsmarknadsföring, samt samverkan mellan kulturarvs-, natur-, och näringslivsaktörer.

- Temat Natur- och kulturarvsturism har handlat om turismens betydelse för hållbar samhällsutveckling samt hur naturen och kulturarvet kan bidra till utvecklingen av turismprodukter, -företag och destinationer.

\subsection{Gemensamma utgångspunkter}

Projektet har eftersträvat ett integrerat perspektiv på natur och kulturarv. Hur samspelar de sinsemellan och tillsammans med ekonomiska och sociala värden? Ett antal gemensamma utgångspunkter eller principer för det arbetet har varit:

- Hållbarhetsperspektivet innebär att det finns en balans mellan ekonomisk, social, kulturell och miljömässig utveckling. Bruket av miljön ska ske på ett sätt som inte förstör kulturarvs- och naturvärdena, nu och på längre sikt.

- Landskapsperspektivet sätter fokus på samspelet mellan natur och kulturarv samt inbegriper även sociala och ekonomiska sammanhang. Landskapet utgör arenan där kulturarv, natur och näringar möts.

- Det historiska perspektivet är viktigt för att kunna förstå vår samtid och varför dagens landskap - med dess livsmiljöer för människor, djur och växter - ser ut som det gör.

- Det demokratiska perspektivet omfattar frågor om tillgänglighet till natur och kulturarv samt människors möjligheter till påverkan och inflytande i beslutsprocesserna. 


\subsection{Det handlar om hållbart bruk}

Hållbarhetsbegreppet har utgjort en grundpelare för hela projektet. Samhällets strävan efter hållbarhet bygger på förhandlingar om lösningar som integrerar de olika hållbarhetsdimensionerna. De som använder naturen och kulturarven behöver se till en hållbar förvaltning samtidigt som natur- och kulturarvsföreträdare behöver se användarnas behov. Vi behöver frångå att det ena intresset står för maximal påverkan medan det andra intresset står för minimal påverkan. För att komma steget längre behöver vi istället diskutera vad som är den bästa möjliga lösningen, både vad gäller kvantitet men även vad gäller kvalitet.

Idag betraktas människan och naturen som integrerade system. Natur- och kulturmiljöns förmåga att stå emot negativ påverkan, klara av förändring och vidareutvecklas varierar och är viktiga faktorer vid bedömningar av vilka lösningar som är hållbara och vilka som inte är det. För att vi ska kunna göra medvetna och långsiktiga val är därför kunskap avgörande.

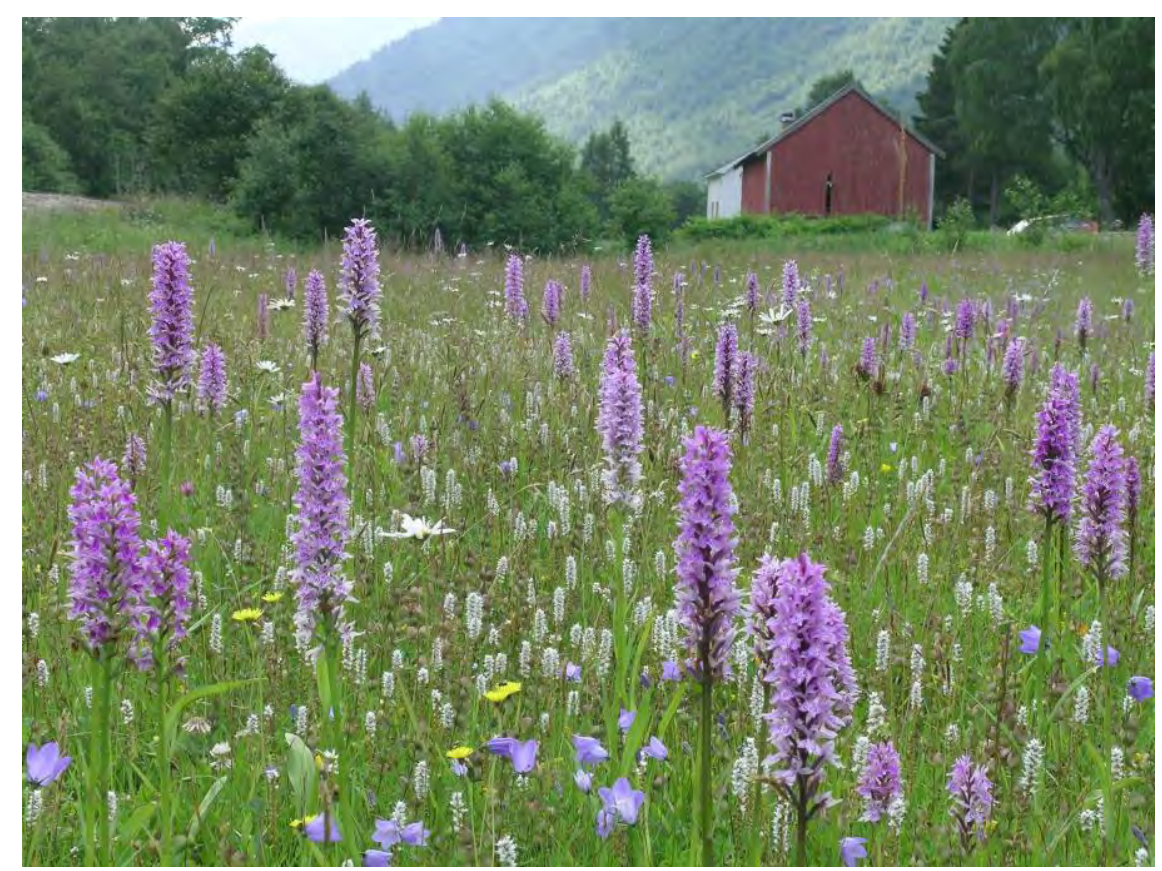

Det vi säkert vet är att allt förändras. Kunskap om människans påverkan på miljön är central för att upprätthålla natur- och kulturvärden. Om natur- och kulturmiljövården ska kunna vara med och påverka villkoren för dagens omställningar krävs att de inkluderas i processerna som förändrar landskapet. Detta innebär nya former av möten mellan det civila samhället, de offentliga myndigheterna och näringslivet. Fotot visar gammal odlingsmark där naturoch kulturvärden har bibehållits genom kontinuerligt bruk över lång tid.

Foto: John Bjarne Jordal. 


\subsection{Synergier mellan natur och kulturarv}

En genomgående fråga i projektet har varit vilka vinster som finns att hämta i ett ökat utbyte och samspel mellan natur och kulturarv. Samspelet kan bidra till långsiktiga kvaliteter och högre attraktivitet. Därmed kan slagkraften öka för att locka företag och besökare, samtidigt som det kan ge en grund för bättre livskvalitet. Det kan även ge starkare argument gentemot ohållbara exploateringsintressen.

Det är positivt för natur- och kulturarvsförvaltningar att uppträda som en part gentemot omvärlden. Myndigheterna kan ge bättre service till alla andra aktörer, t.ex. genom att erbjuda gemensam kunskap och information. En tydlighet utåt skapas om budskapen är samordnade - i detta är det viktigt att tydliggöra såväl lika som skilda åsikter.

Det finns även samhällsekonomiska fördelar i en ökad samordning mellan natur och kulturarvsmyndigheter genom att byråkratin effektiviseras och att det sammantaget skapas bättre förutsättningar för hållbar tillväxt.

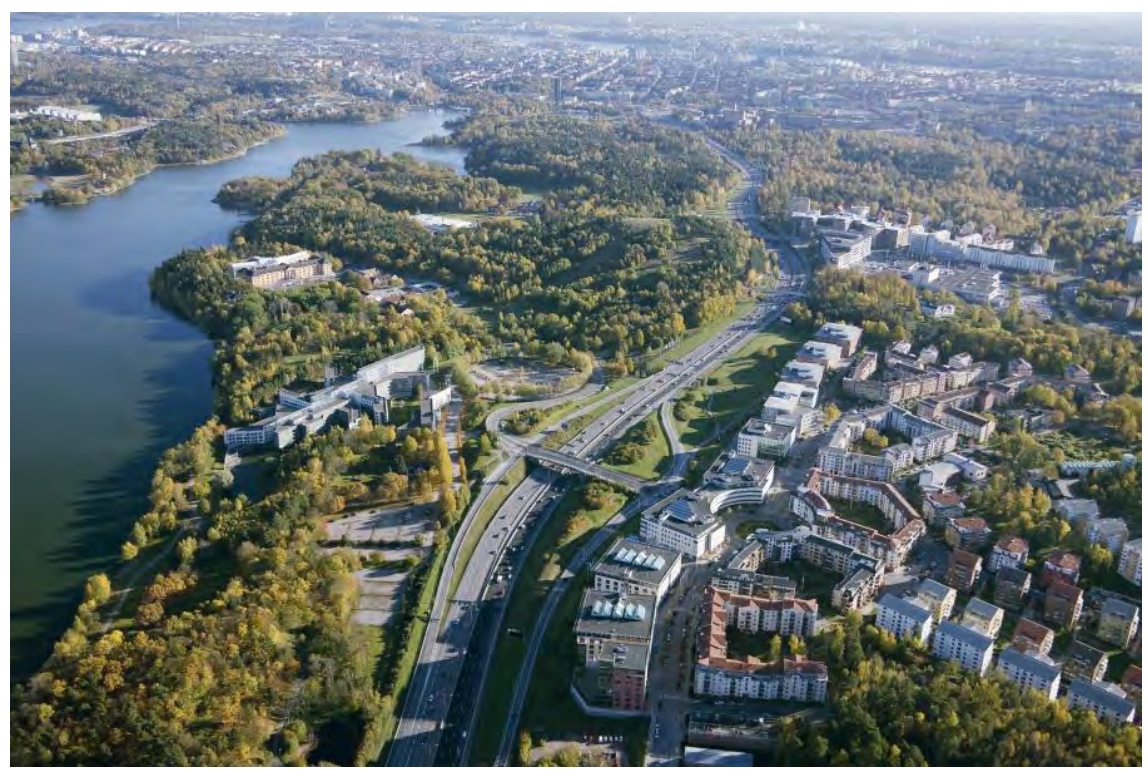

Natur- och kulturvärden kan förstärka varandra och $i$ sin tur ge upphov till ökade ekonomiska, sociala och kulturella utbyten. Detta förutsätter att man är klar och tydlig över vilka värdena är. Med "värdekartan" tydliggjord finns en plattform för att peka ut färdriktning och välja lämpliga samarbetspartners. Bilden visar delar av nationalstadsparken i Stockholm.

Foto: Jan Augustsson 


\subsection{Projektets koppling till styrdokument}

Erfarenhetsutbytet och samverkan inom projektet kommer att underlätta främjandet av nordiska synpunkter i internationella sammanhang. I kartläggningen i etapp 1 (TemaNord 2009:513)identifierades en rad internationella konventioner och policys som har betydelse för arbetet med projektets tema som Europeiska landskapskonventionen, UNESCO:s världsarvskonvention och FN:s konvention om biologisk mångfald i Norden. Detta projekt har även stark koppling till Nordiska ministerrådets miljöhandlingsprogram (ANP 2008:733) och strategi för hållbar utveckling (ANP 2009:726).

I kartläggningen lyftes även några viktiga nation-ella strategier och principer fram i förhållande till projektets teman. Nedanstående lista gör inte anspråk på att vara heltäckande.

I Norge har projektet bland annat koppling till Regjeringens reiselivsstrategi, Stortingsmelding nr 16 (2004-2005) om kulturminnepolitiken, kapitlet om Fjellområdene - bruk, vern og verdiskaping i St.prpr.nr. 65 (2002-2003). Stortingsmeldinger från senare år från flera departement omtalar natur och kulturarv som viktiga för god livsmiljö och näringsutveckling.

I Sverige har projektet bland annat relevans för det nationella styrdokumentet för regional tillväxtpolitik; En nationell strategi för regional konkurrenskraft, entreprenörskap och sysselsättning 2007-2013. Därtill har det t.ex. bäring på det svenska landsbygdsutvecklingsprogrammet 2007-2013 samt Sveriges arbete med de nationella miljömålen.

I Danmark har projektet bland annat bäring på kommunalreformen 2007, vilken gav kommunerna större befogenheter för utveckling av både stad och landsbygd. Kopplat till detta har staten arbetat med nya ramar för den kommunala planeringen och regionernas utvecklingsplaner.

I Island har projektet bland annat koppling till Miljöministeriets rapport Välfärd till framtiden, hållbar utveckling i det isländska samfundet prioriteringar 2010-2013 och strategin om kulturturism.

I Finland har projektet bland annat bäring på det nationella skogsprogrammet 2015, arkitekturpolitiken och handlingsprogrammet för kultur- och naturturism 2008-2013.

På Färöarna har projektet bland annat bäring på strategin för det färöiska samhället - Vision 2015, och arbetet med varumärket Färöarna. 


\subsection{Deltagare i projektet}

Norge ansvarar genom Riksantikvaren för projektledning och Sverige genom Riksantikvarieämbetet för projektsekreterarskap.

Per-Olof Remmare, Riksantikvarieämbetet, Jesper Taube, Naturvårdsverket och Geir Tvedt, Riksantikvaren tog inledande kontakter med berörda natur- och kulturarvsmyndigheter, formulerade projektbeskrivning och projektansökan till Nordiska ministerrådet och lade därmed grunden till projektet.

Följande personer och myndigheter har varit representerade i projektet:

- Norge:

○ Riksantikvaren - Jostein Løvdal (ordförande). Etapp 1-3

- Riksantikvaren - Stene Berg. Etapp 1-2

○ Riksantikvaren - Geir Tvedt. Projektansökan och etapp 2-3.

- Direktoratet for naturforvaltningen - Reidar Dahl. Etapp 1-3

- Sverige:

○ Riksantikvarieämbetet - Daniel Nilsson (sekreterare). Etapp 1-3

- Riksantikvarieämbetet - Nataliya Hulusjö. Etapp 1-3

- Naturvårdsverket - Jesper Taube. Projektansökan och etapp 1-2

- Naturvårdsverket - Ingvar Jundén. Etapp 2-3

- Danmark:

○ Kulturarvsstyrelsen - Thyge Moos. Etapp 1

- Kulturarvsstyrelsen - Louise Straarup. Etapp 2

- Kulturarvsstyrelsen - Morten Stenak. Etapp 2-3

- Skov- og Naturstyrelsen - Mikael Kirkebæk. Etapp 1

- Island:

- Fornleifavernd Ríkisins (Statens Fornminnesvård) - Agnes Stefánsdóttir. Etapp 1-3

○ Umhverfisstofnun (Miljöstyrelsen) - Hjalti Guðmundsson. Etapp 1.

- Umhverfisstofnun (Miljöstyrelsen) - Guðbjörg Gunnarsdóttir. Etapp 2-3

- Finland:

○ Museiverket - Maria Kurtén. Etapp 1-3

- Museiverket - Kaija Kiiveri-Hakkarainen. Etapp 1-3

- Museiverket - Maire Mattinen. Etapp 1-2 
- Färöarna:

- Føroya Náttúrugripasavn (Naturhistoriskt museum) - Anna Maria Fossaa. Etapp 1-3

- Føroya Fornminnissavn (Kulturhistoriskt museum) - Helgi Michelsen. Etapp 1-3 


\section{God livsmiljö}

\subsection{Introduktion till tema och konferens}

Både byer, landsbyer og det åbne land rummer natur- og kulturarv. Ofte bor og færdes mennesker i og omkring væsentlig natur og kulturarv uden at være klar over det. Vi ved fra Kulturarvsstyrelsens og Realdanias undersøgelse fra 2005 Kulturarv en væsentlig ressource for kommunernes udvikling, at såvel virksomheder som borgerne lægger vægt på at bosætte sig i områder, der rummer væsentlig kulturarv. Det gør de fordi kulturarven bidrager til den lokale identitet og medvirker til at give individet et forbedret livsmiljø med den betydning, det har for livskvaliteten. Det handler om at forstå det sted man bor, om at kunne aflæse natur- och kulturhistorien i omgivelserne og opbygge veneration for den lokale natur- och kulturarv.

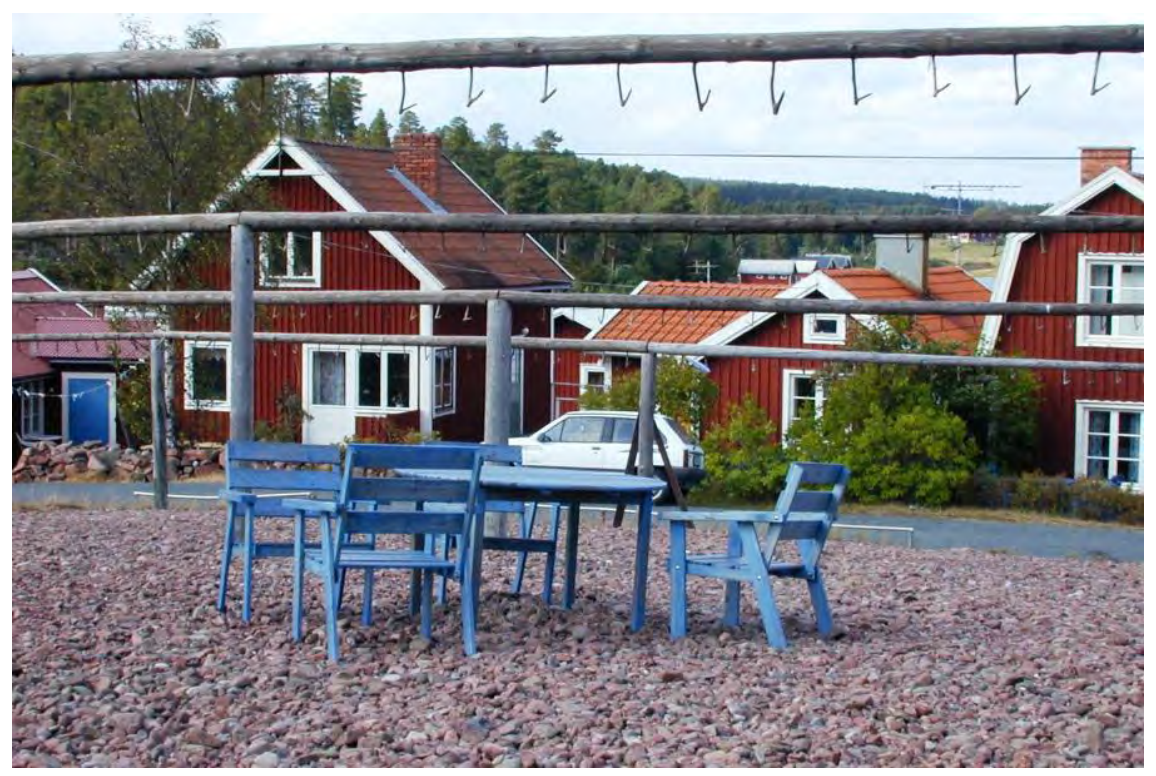

Garnupphängningsplats och rum för samvaro.

Foto: Daniel Nilsson

Kommunernes opgave er derfor at arbejde med at gøre natur- og kulturarven tilgængelig og forståelig for borgerne og virksomhederne.

Inden for planlægningens verden har der de seneste 20-30 år været mange bud på, hvordan vi kan udvikle nye former for planlægning, der både kan bidrage til at sikre kvaliteten af vores fysiske opgivelser, men også medvirke til at danne ramme om et godt socialt liv. Ønsket om at 
udvikle nye former for planlægning skal blandt andet ses i lyset af, at tidligere tiders funktionsadskillende, sektororienterede og top-down styrede planlægning har vist sig uden af stand til at løse de problemer, den var sat i verden for at løse. Men ønsket bunder også i, at gode rammebetingelser for bosætning er blevet en konkurrenceparameter i kommunernes bestræbelser på fastholde befolkningen i landdistrikterne og tiltrække højtuddannet arbejdskraft. Samtidig er gode og grønne omgivelser med stier blevet fremhævet som en vigtig sundhedsfaktor. Udvikling af "steder": bysamfund, lokalområder eller landskaber med en mangfoldig natur og en rig kulturarv, som er karakteristiske, og som er fysisk og socialt velfungerende, er således i dag både et mål og et middel i udviklingen et bæredygtigt samfund (Healey, 1998; Healey, 2009).

Den Europæiske Landskabskonvention, understreger, at alle typer landskaber har en værdi. Både hverdagslandskabet, der danner ramme om vores almindelige liv og produktion, og de særligt værdifulde landskaber, både naturlige og menneskeskabte. Konventionen nævner også, at ødelagte landskaber og landskaber i en negativ udvikling bør have vores opmærksomhed. Konventionens hovedbudskab er, at vi skal bevidstgøre os om landskabet, at vi skal anlægge et helhedssyn, og at der bør laves langsigtet planlægning og forvaltning for alle dele af landskabet. Alle berørte parter bør desuden have mulighed for at deltage og bidrage, når landskabets værdier diskuteres, og når der laves plan og strategier for deres nuværende og fremtidige forvaltning (Council of Europe, 2000).

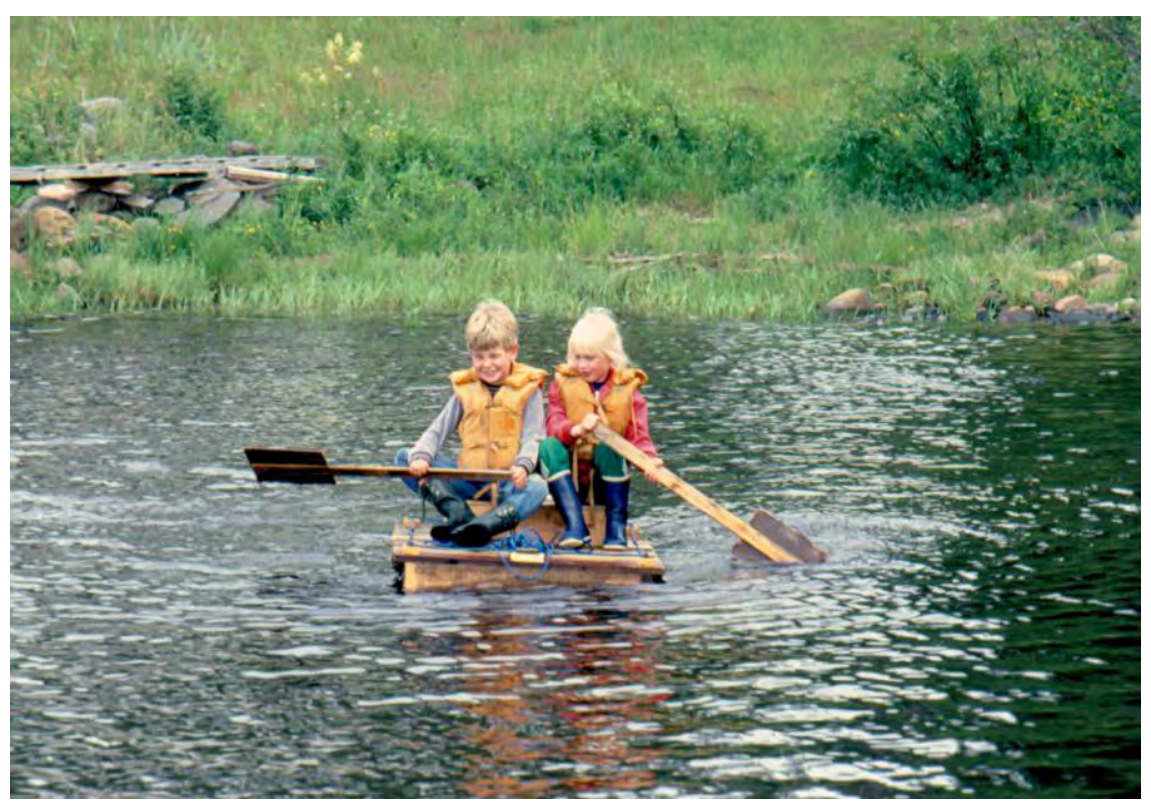

Natur- och kulturmiljöer kan stimulera till äventyrslekar och upptäcktsfärder.

Foto: Ingvar Jundén. 


\subsection{Konferens - Den goda vardagen}

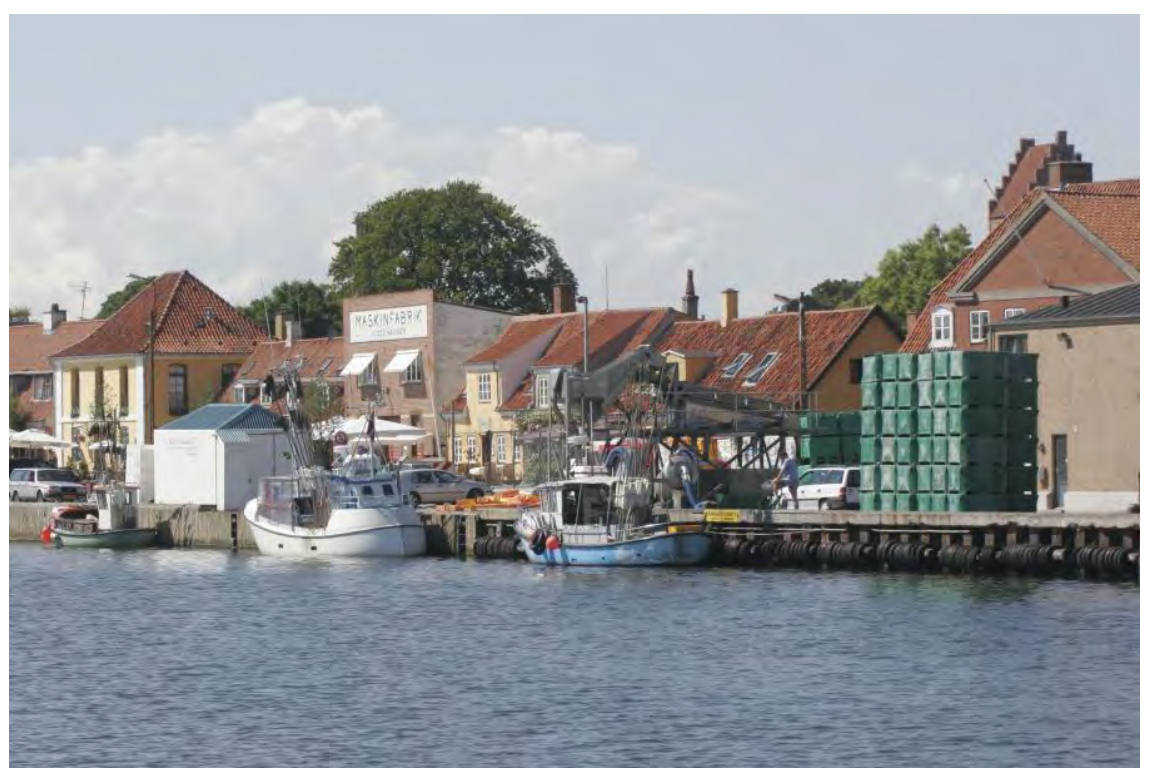

I Køge finns det endast en fiskare kvar. Kommunen har gjort en kulturplan för den gamla industrihamnen Søndre Havn där konst- och kulturlivet har en viktig roll för återanvändning och omvandling av miljöns tomma industribyggnader.

Foto: Ole Akhøj.

Konferensen Den goda vardagen om god livsmiljö hade fokus på hur Nordens kommuner arbetar med natur och kulturarv som faktorer i utvecklingen av god livsmiljö och lokal utveckling. Ett annat syfte var att kasta ljus på perspektiven, strategierna och metoderna som används, inklusive hur natur- och kulturarvsmyndigheter kan underlätta och bidra i arbetet. Nedan följer ett sammandrag av viktiga erfarenheter, konklusioner och önskemål från konferensen.

\section{Statens roll}

Det är viktigt att staten är med och skapar goda långsiktiga ramvillkor som stödjer lokala satsningar och initiativ. Statens roll sammanfattas här under tre punkter: samordnad stat, igångsättning av nya initiativ och dialog som arbetsmetod.

\section{Samordnad stat}

Goda rambetingelser fodrar samarbetsvilliga och samordnade offentliga aktörer där kommunikation, rollfördelning och samspel är viktiga faktorer. Samverkan är nödvändig, såväl mellan kulturarvs- och naturmyndigheter som mellan stat, region och kommun. Det behövs en ökad tydlighet om vilken roll staten tar på sig och i vilken situation. Det kan exempelvis handla om vem som ska betala vad och när. Dessutom behöver förutsättningarna för samfinansiering över sektorsgränserna förbättras och eventuellt möjligheterna till gemensamma finansieringsprogram ses 
över. Staten bör ha ett ansvar för att utveckla mötesplatser för erfarenhetsutbyte mellan berörda aktörer.

\section{Igångsättning av nya initiativ}

Statliga ansatser, i form av både professionella och ekonomiska bidrag, är en viktig drivkraft för att sätta igång nya och innovativa utvecklingsprojekt i kommuner. Utgångspunkt för dessa initiativ bör även vara att starta nya långsiktiga processer i de kommunala förvaltningsorganen. Igångsättningen kan med fördel ske i form av exempelprojekt, där stat, kommun och andra intressenter arbetar samman. I avtal mellan stat och kommun/ lokala organisationer är det betydelsefullt att besluta om tillräckliga tidsramar för att säkra väl fungerande processer som möjliggör delaktighet från medborgarna och berörda intressenter.

En statlig uppbackning av projekten i form av medfinansiering är central. Detta kan gärna ske i form av ramprogram där de statliga myndigheterna sätter upp mål, överordnade kriterier och villkor, men samtidigt låter de lokala aktörerna själva definiera sina projekt. Ramprogrammen bör följas upp med facilitering för att säkra kompetensutveckling, erfarenhetsutbyte och nätverksformering.

\section{Dialog som arbetsmetod}

Staten förväntas idag gå i dialog med andra aktörer för att diskutera vägval och tillsammans hitta lösningar på aktuella utmaningar. Myndigheterna behöver utveckla en form av "mellanrumskompetens" för att kunna fungera som bro mellan det offentliga och det privata, samt mellan det strategiska och det praktiska.

Detta skulle underlättas av en ökad mellankommunal samverkan där staten inbjuds att samarbeta med kluster av kommuner kring gemensamma frågor. Det handlar om att se till platsens karaktär snarare än till dess administrativa gränser. Att kommunöverskridande projekt bidrar till ett ökat erfarenhetsutbyte och lärande blir då en bonus.

\section{Planera för det "goda livet"}

Under de senaste decennierna har det lagts många förslag på hur vi kan utveckla nya former för planering. Dessa har avsett att bidra till att säkerställa kvaliteten i den fysiska miljön, men också att utforma ramarna för ett gott socialt liv. Bland de nya planeringsformer som har uppstått finns till exempel kommunikativ planering, som inkluderar medborgarna i planeringsprocesserna, och cultural planning, som betonar den strategiska och tvärvetenskapliga användningen av de kulturella resurserna.

Kommunerna har en viktig roll för att hålla ihop den lokala demokratiarenan. Ökad delaktighet ger förutsättningar för bredare underlag för beslutsfattare och dessutom en förstärkt demokratisk legitimitet åt de beslut som fattats. $0 \mathrm{~m}$ beslutsprocesserna präglas av lokalt deltagande och lokal kunskapsuppbyggnad kan det kollektiva ansvaret för miljön 
med dess natur- och kulturarvsvärden också stärkas - det är fundamentet för bevarande och utveckling av en god livsmiljö.

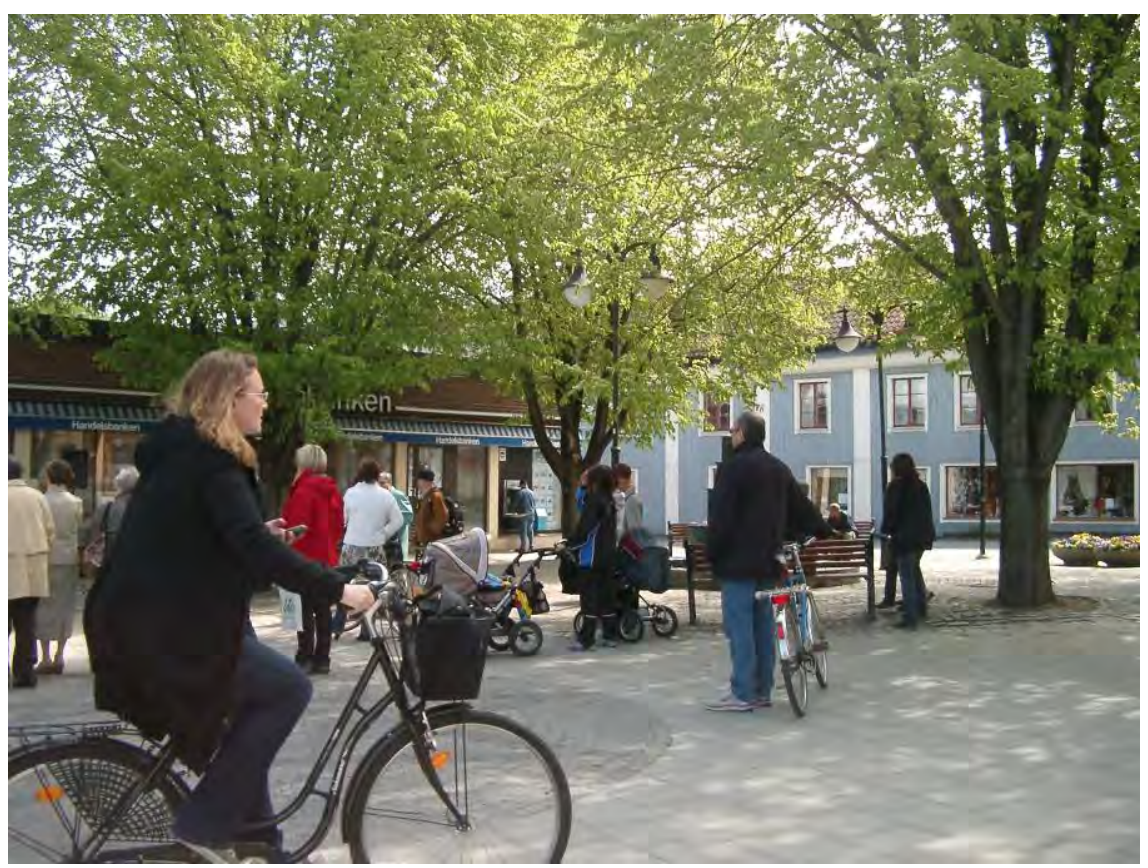

Den moderna planeringen handlar om en lång process där många olika aktörer medvetet bör involveras. Som nyckel till framgång utpekades sådana företeelser som engagemang, kommunikation, tålamod och envishet.

Foto: Ann Mari Westerlind.

Då är det också betydelsefullt att lokala projekt integreras till en helhet med kommunernas planläggning samt annan strategisk planering och resursanvändning för att möjliggöra ett långsiktigt arbete och en resultatgivande utveckling. Det är viktigt att säkra kulturarvs- och naturvårdskompetenserna i kommunal planläggning och i närings- eller utvecklingsarbete.

\section{De ideella krafternas värdeskapande betydelse}

Det är av grundläggande betydelse att människor ges möjlighet att delta i utvecklingen av sin omgivning. Det har visat sig att om den lokala verksamheten organiseras på ett bra sätt blir engagemanget mer robust och kan upprätthållas under en lång tid. 


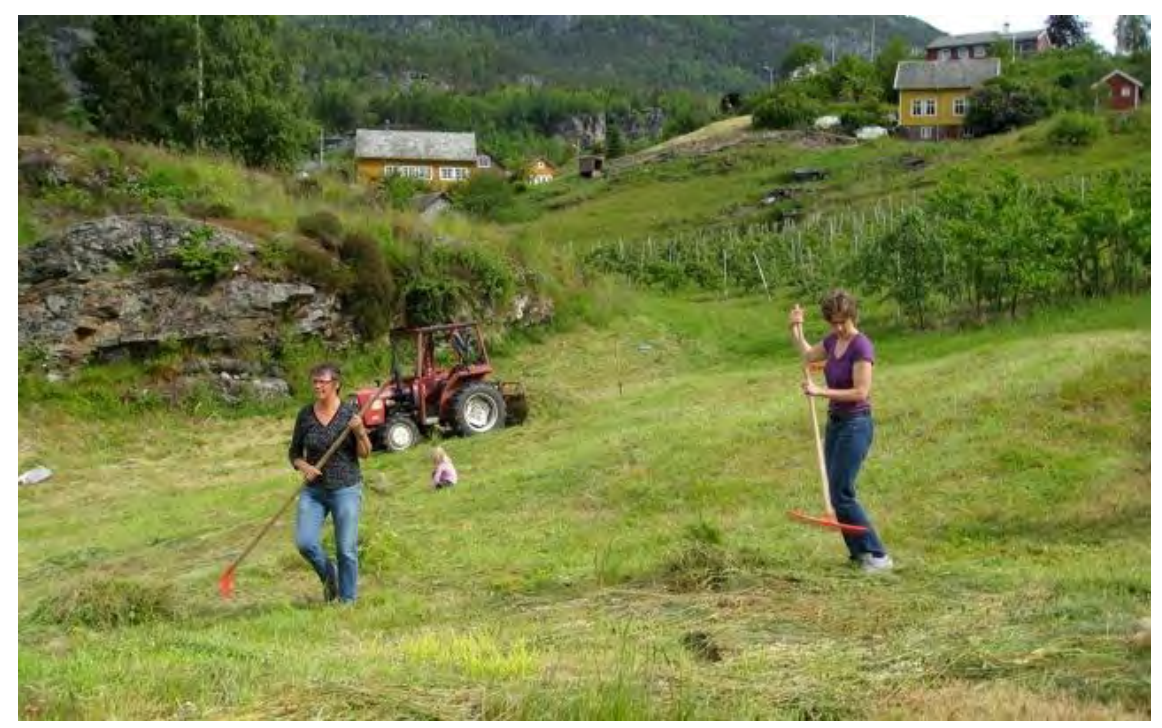

Projektet "Herand - den kulturhistoriske bygda" i Norge startade för 12 år sedan. Det hölls flera medborgarmöten där man enades om att natur- och kulturmiljön var en positiv resurs för området. Detta ledde i sin tur fram till huvudstrategin för projektet: "at skabe sammenhold og kollektivt ansvar for det nære miljø og dets fremtid."

Foto: Haldor Tuvin.

När eldsjälar startar projekt är det viktigt att offentliga aktörer stödjer dem istället för att styra eller lämna dem ensamma. För att projekten ska kunna vara långsiktiga bör de samtidigt bygga på mer än eldsjälar. Det stora engagemanget från de ideella föreningarna kan behållas genom att till exempel räkna eget arbete som medfinansiering.

\section{Behov av förmedlings- och kommunikationsstrategier}

Förmedling av natur- och kulturarv är centralt för att göra värdena tillgängliga och skapa ökad förståelse för deras olika betydelser. Medborgare, politiker och experter talar delvis olika "språk" och kommunikationen bör därför målgrupps- och situationsanpassas. Erfarenheter visar att det ofta är viktigt med en tydlig och enkel berättelse samt en visuell förmedling för att bygga gemensam förståelse som grund för dialog. Arbetet med att fastställa en gemensam kommunikationsplattform som bas för utvecklingsarbete bör därför inte underskattas.

En mer samordnad förmedling av natur och kulturarv efterfrågas. Det handlar t.ex. om gemensam marknadsföring och spridning av goda exempel på hur värdena kan vara en resurs för lokal utveckling. Det finns även ett behov av att kommunicera och tydliggöra samband mellan natur och kulturarv för att öka förståelsen och överbrygga sektorsintressen. 
Rekommendationer; kunskaps- och erfarenhetsutbyte:

- Det bör satsas mera på erfarenhetsinsamling och förmedling av resultat från innovativa projekt.

- Det finns ett specifikt behov av insamling av erfarenheter från projekt som bygger på medborgardelaktighet; Vilka kunskaper och kompetenser finns det behov av att tillföra dessa projekt? Vad särskiljer lyckade projekt från mindre lyckade projekt? Vilka språkliga barriärer existerar mellan medborgare och myndigheter?

- Det finns ett specifikt behov av att samla in erfarenheter om förmedlingsmetoder i förhållande till den kommunpolitiska nivån och i förhållande till medborgarna - vilka historier, berättelser, fysiska strukturer och objekt är det lätt för politikerna och medborgarna att identifiera sig med.

- Det är väsentligt att koppla samman kulturarvs- och naturresurserna med folkhälsoperspektivet.

- Det finns behov av metodutveckling vad gäller kvalitetssäkring av projekt.

\section{Bredda synen på vad som är värdefulla områden}

Flera projekt visar att synen på vad som är värdefull mark behöver breddas. Ett exempel är kulturmiljöer i form av övergivna industriområden där annorlunda biotoper/ livsmiljöer har skapats. Den tätortsnära naturen spelar stor roll på många plan. Forskning kring fysisk aktivitet hos barn demonstrerar att närheten till grönområden är viktig för att barnen ska komma ut och röra på sig. Av den anledningen är det angeläget att bevara även små grönområden som idag används av förskolor och skolor. Natur och kulturarvens betydelse för trivsel och attraktionskraft i bostadsområden är befäst. Denna trivsel har även betydelse för värdet på fastigheterna i området, vilket pekar på att natur- och kulturmiljöer bör ses som en värdehöjande del i samhällsbilden. 


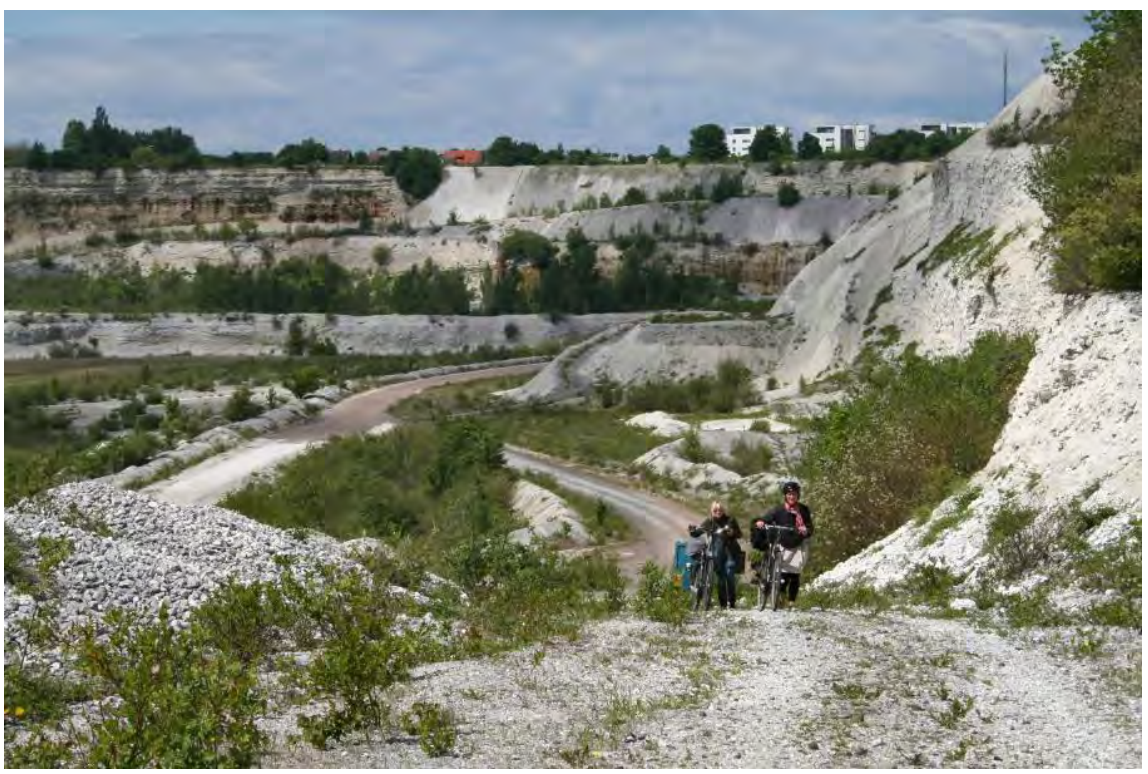

Limhamns kalkbrott $\mathrm{i}$ Malmö är ett före detta industriområde i vilket annorlunda biotoper/livsmiljöer har skapats. Denna enorma grop är idag ett storslaget industriminne och klassas som ett särskilt värdefullt naturområde.

Foto: Morten Stenak.

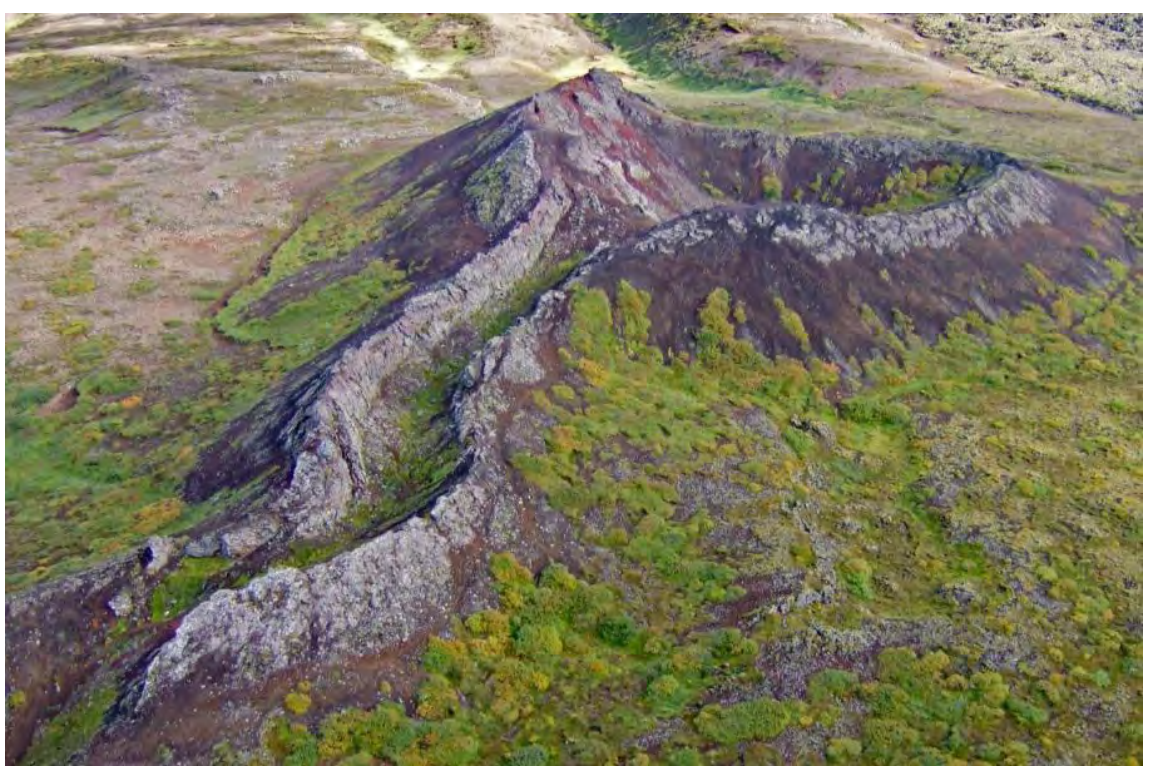

I Island har Garðabær kommun arbetat för att bevara en 7000 år gammal lavaflod som en del av vardagslivet, där området blivit rum för fritid och ett motiv inom konsten.

Foto: Árni Geirsson. 


\section{Använd natur och kulturarv som drivkraft för stads- eller områdesförnyelse}

Natur och kulturarv kan vara en drivkraft eller utgångspunkt för vitalisering och utveckling av en stads eller ett områdes identitet. Natur- och kulturhistoriska värden behöver först identifieras och tolkas för att därefter kunna hävdas aktivt i omvandlingen. Erfarenheten visar att när man strategiskt försöker återanvända historiska byggnader och generera visuella berättelser om en plats kan ringar på vattnet skapas. Det är viktigt att anpassa metoder efter specifika lokala förhållanden, såsom social struktur, utbildning, geografi och politisk struktur. En risk i sammanhanget är att medvetet identitetsskapande utifrån kulturarv riskerar att fungera särskiljande mellan grupper och människor istället för att ge en inkluderande funktion.

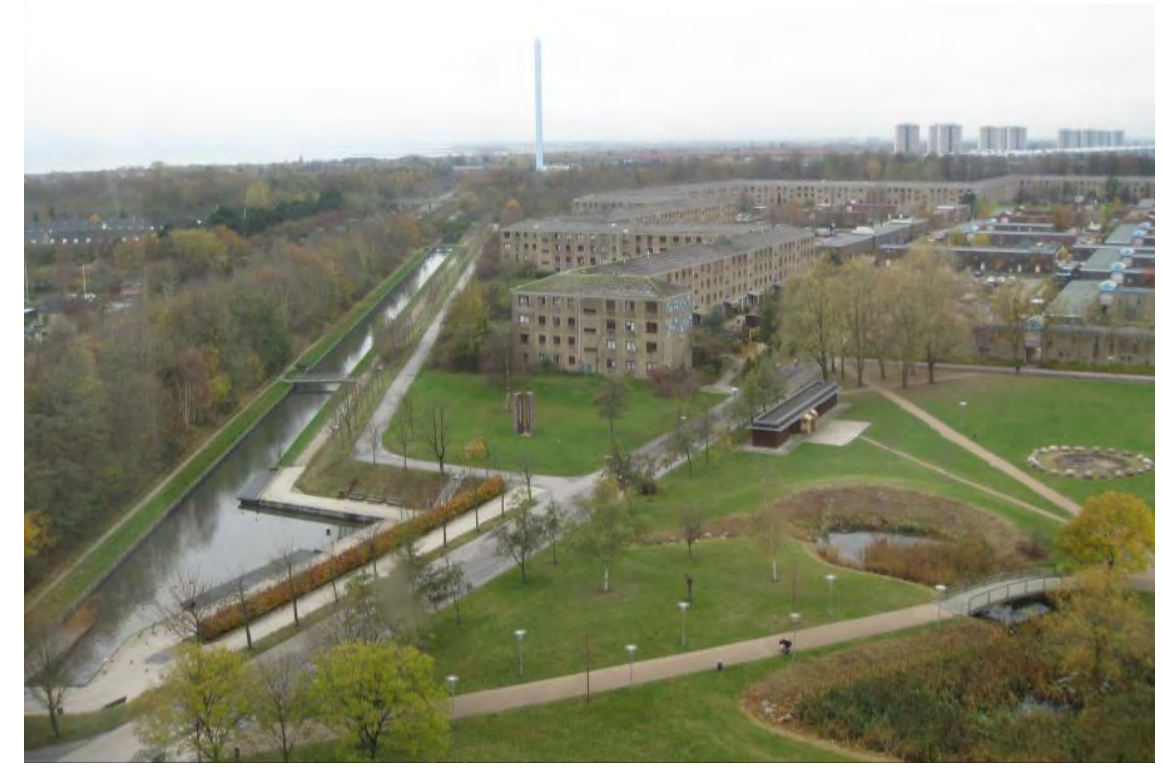

I Hvidovre kommun i Danmark har man lyft fram drömmarna om välfärdssamhället. Först tar man fasta på historien, eller berättelsen, för att sedan finna artefakten. Ur mängden berättelser väljs dem man vill arbeta vidare med för framtiden. Nästa steg är att peka ut den artefakt, exempelvis en byggnad, som återspeglar berättelsen, eller den tradition som ligger bakom ett bestämt sätt att bygga på. Slutmålet är att identifierad natur och kulturarv används som resurser i lösandet av de samtida samhällsproblemen i kommunen.

Foto: Louise Straarup.

I utvecklandet eller gestaltningen av mötesplatser har det ofta visat sig att de med fördel kan ta sin utgångspunkt i natur och kulturarv. Sociala skillnader påverkar hur miljöer eller platser används. Olika preferenser vad gäller synen på landskap och platser är därför ett viktigt underlag i områdesutvecklingen. 


\section{Från någon annans mun...}

"Bättre att gå på halvfart under en lång tid än full fart under en kortare tid." Gertrud Richter, Örkeljunga kommun (SE)

"Förbättra möjligheterna för kommunerna att kommunicera horisontellt." Ingegerd Ward, Naturvårdsverket (SE)

"Har du ett gott projekt så finner du finansiering förr eller senare." Una Eiken, Herand Landskapspark (NO)

"I mötet mellan invånarna och experterna kan vi skapa något mycket gott!" Anders Rask Storgaard, Skive Kommune (DK)

"Glöm inte bort folkhälso- och barnperspektivet!" Nina Granath, Nacka kommun (SE)

"Planläggning av kulturarvet är framtiden."

Steen Hvass, Kulturarvsstyrelsen (DK) 


\section{Näringsutveckling}

\subsection{Introduktion till tema och konferens}

Människors innovationer, företagsamhet och verksamheter har i samspel med naturgivna förutsättningar format våra nordiska landskap. Spår av näringsutvecklingen från förhistorisk tid till våra dagar syns $\mathrm{i}$ växtlighet, fornlämningar och byggnadsarv. De bildar lager på lager i landskapet, såväl på landsbygden som i industrisamhällen och metropoler. Under temat natur, kulturarv och näringsutveckling granskade vi det kreativa samarbete mellan offentliga och privata aktörer som kan göra landskapets mångfald av egenskaper till resurser för en kulturhistoriskt, socialt och ekologiskt hållbar ekonomisk tillväxt.

Ekonomiska studier rymmer många synvinklar. Initiativ och åtgärder har både direkta effekter och indirekta verkningar. Resultatet av en ekonomisk analys kan se mycket olika ut beroende på om man studerar vinsten för privata ägare, lönsamheten för samhället eller nyttan för det gemensamma goda.

\section{Har det unika och okända eller det bekanta och gemensamma mer dragningskraft?}

Det finns stor ekonomisk potential i det byggda kulturarvet, kulturmiljön och naturen och marknadsmekanismerna spelar en central roll i upprätthållandet och utvecklingen av dem. Historiskt betydelsefulla byggnader och landskap kan förvaltas på olika sätt. Man kan välja att konservera, restaurera eller göra moderna tillägg. Hur påverkar valet av inriktning värdet på den enskilda fastigheten och hela området som den är en del av? Samhällsplanerings- och planläggningsprocesser är arenor med stor potential för skapandet av en positiv dynamik mellan kontinuitet och förändring samt mellan det privata och det gemensamma goda.

\section{Är det läget eller tillgängligheten som är avgörande?}

Platsens läge är låst, men tillgängligheten kan man förbättra både fysiskt, kunskapsmässigt och socialt. Hur hittar producenter och konsumenter fram till det de eftersträvar? De offentliga aktörernas uppgift är att skapa en fungerande infrastruktur, både fysiskt och kunskapsmässigt, så att människorna kreativt kan utveckla näringar och företag på ett hållbart sätt. Mångfald är en central komponent i hållbar utveckling.

\section{Hur fattar man goda utvecklingsbeslut?}

Klimat, naturtillgångar och samhälleliga utmaningar ändras över tid. Globala och lokala utmaningar och möjligheter är sammanflätade och 
sambanden är delvis svåra att begripa. Efter andra världskriget betydde ekonomisk tillväxt och ökad BNP ökad välfärd, men nu är situationen en annan. Forskare, statliga myndigheter och internationella organisationer söker nya mätmetoder som inte enbart granskar produktionens volym, utan också beaktar dess påverkan på miljön och den sociala stabiliteten. Politikerna väljer vilka värden som prioriteras i lagstiftning och offentlig finansiering, men vi fattar alla beslut, som producenter, konsumenter och medborgare. Vi kan välja att främja en hållbar näringsutveckling.

\subsection{Konferens - Natur, kulturarv och näringsutveckling}

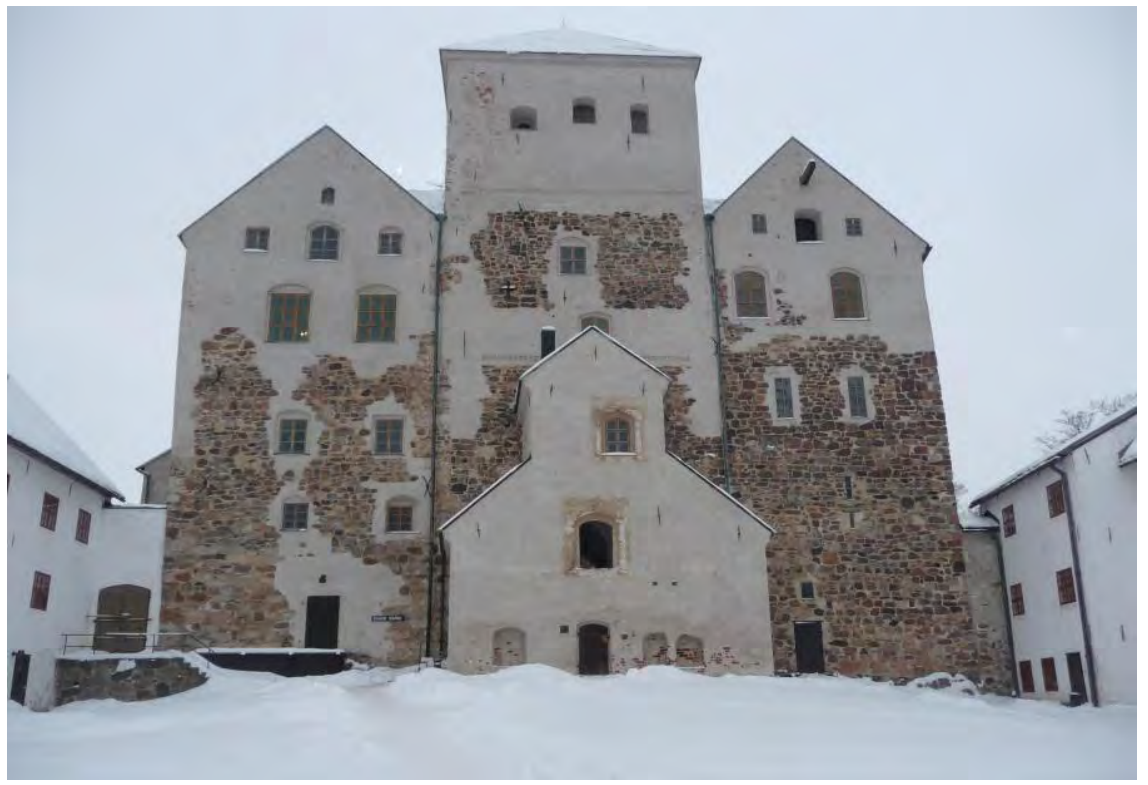

Konferensen var förlagd till Åbo slott i Finland.

Foto: Nataliya Hulusjö

Natur och kulturarv har fått en större betydelse för entreprenörskap och företagande. Samtidigt finns det behov av att ytterligare ta tillvara potentialen och utveckla frågorna inom många områden. Denna konferens behandlade överordnade perspektiv på landskapet som resurs för näringsutveckling samt lokal profilering utifrån kulturarvs- och naturvärden. Även nedslag i några specifika näringar gjordes där natur och kulturarv har varit viktiga för att utveckla entreprenörskapet och öka företagandet.

Nedan följer ett urval av centrala frågor, erfarenheter och slutsatser från konferensen. 


\section{Att skapa värden i ett samspel mellan det lokala och det globala}

Basen för närings- och företagsutveckling bildas av lokala resurser i samverkan med den globala ekonomin och styrande internationella avtal. Dessa förutsättningar förändras i ständigt pågående processer; befolkningsstruktur och miljön förändras, innehåll i avtal förnyas med jämna mellanrum och målsättningarna och styrmedlen justeras i ständigt återkommande förhandlingar om vilka värden som ska prioriteras i internationell samverkan och lokal produktion. Det är en stor fråga hur man ska bruka och fördela nyttan av både materiella och immateriella resurser baserade på natur och kulturarv.

Ekonomiska, miljömässiga, kulturella och sociala värden bygger på varandra i ett samspel mellan privata och kollektiva tillgångar och aktiviteter och i samverkan mellan det lokala och det globala.

\section{Kommersiell användning av gemensamma tillgångar}

Användning i vinstsyfte av offentligt ägda egendomar och fastigheter samt nyttjande av marker till vinstdrivande verksamhet kan krocka med allemansrättsliga och/eller enskilda markägarintressen. I arbetet med regionala och lokala tillväxtfrågor rörande natur och kulturarv ligger därför en utmaning $\mathrm{i}$ att hantera privat nyttjande av gemensamma tillgångar.

En komplicerande faktor kan vara att aktörer agerar utifrån olika tidsperspektiv. Kommersiella aktörer har ofta höga krav på snabb lönsamhet för insatser och investeringar. Hänsynen till natur och kultur kan då väga lätt trots att denna hänsyn kanske även är det mest ekonomiska i det långa perspektivet.

Metoder för samhällsekonomiska värderingar av natur- och kulturmiljön är bra för att kunna visa på de ekonomiska nyttor som natur och kulturarv kan bidra till. Det är dock viktigt att kvalitativa nyttor som inte går att beräkna monetärt inte hamnar i strykklass. Insatser och investeringar bör analyseras även gentemot förtjänster och kostnader som inte går att prissätta.

\section{Natur och kulturarv som infrastruktur för näringsliv}

Natur och kulturarv kan utgöra en bas för olika kommersiella verksamheter. På samma sätt som staten understödjer näringslivet genom att t.ex. bygga vägar kan den även bidra till infrastruktur rörande natur och kulturarv. Staten och andra offentliga insatser kan bland annat se till att skyddade natur- och kulturmiljöer tillgängliggörs för ekonomiska aktiviteter. Iordningställande av leder, serviceanläggningar med mera inom dessa områden skapar sysselsättning, liksom ökade förutsättningar för långsiktigt hållbara verksamheter. Samtidigt bör en diskussion föras om hur även kommersiella aktörer ska bidra till vård och underhåll av natur och kulturarv. 


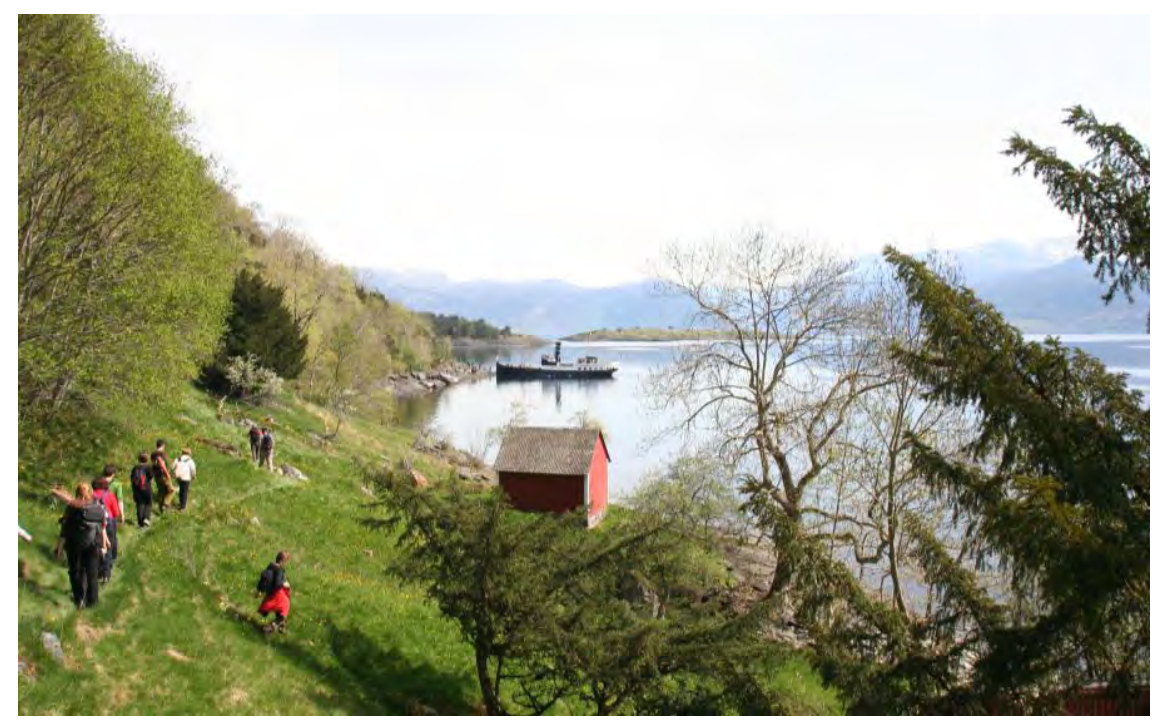

Bilden visar en guidad tur $\boldsymbol{i}$ reservatet Gjuvlandslia landskapsvernområde $\boldsymbol{i}$ Norge. I skötseln av landskapet ingår bland annat röjning av träd. Ångbåten DS Oster i bakgrunden är en veteranbåt som idag drivs av en vänförening.

Foto: Marie Lier.

\section{Efterfrågan styr marknaden}

Platser har många olika betydelser för skilda intressenter, vilket innebär att en produkt kan säljas till många olika målgrupper. Vad som egentligen är en resurs för utveckling är inte givet och efterfrågan ändras också över tid. Om natur och kulturarv bättre ska tas tillvara som en resurs i lokalt och regionalt utvecklingsarbete behöver det traditionella expertperspektivet kompletteras med nya arbetssätt som även har marknaden som utgångspunkt.

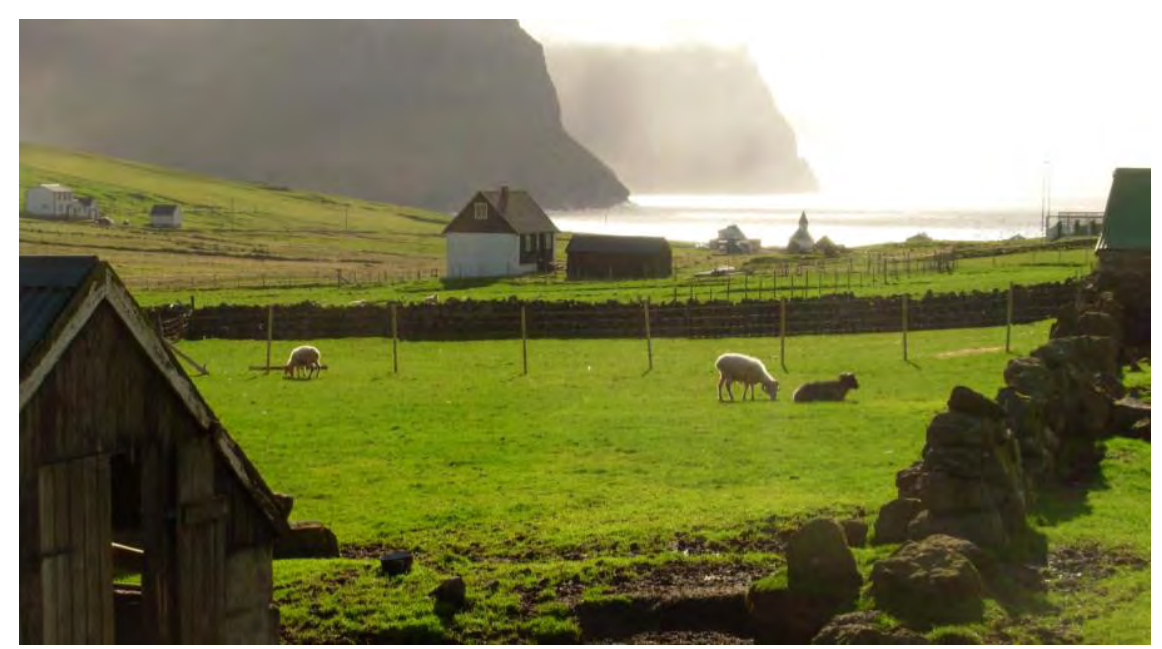

En stor del av föredragshållarna talade om storytelling som metod för marknadsföring och prissättning av produkter. Färöarna har t.ex. arbetat med att skapa en konkurrenskraftig identitet baserad på öarnas natur, kultur och kulturarv.

Foto: Ingvar Jundén. 
Det finns en tendens till likriktning i marknadsföring av platser trots att alla försöker framhäva just det "unika". Det speciella med kulturarv och natur är att de tillför en dimension som fokuserar på det som är angeläget och viktigt med ett landskap, område eller en plats. Detta skapar ett djupare innehåll och en starkare upplevelse. De platser eller destinationer som utvecklar naturen och kulturarvet kan därför ha mycket att vinna.

\section{Utveckla entreprenörskap och företagande}

Det är betydelsefullt att skapa goda förutsättningar för entreprenörer och företagare som bedriver verksamhet på natur- och kulturarvsgrund att utveckla sina affärsidéer. En möjlig väg kan vara satsningar på inkubatorer eller andra former av entreprenöriella miljöer som syftar till att hjälpa och guida unga företag. Offentliga institutioner kan bland annat bidra med att visa på möjligheter för företagande inom området. Natur och kulturarv kan t.ex. vara en inspiration för hantverk och andra kreativa verksamheter där de blir utgångspunkt för design av varor.

Exempel:

Exemplet om economusee visar hur hantverkstraditioner kan hållas vid liv och dessutom generera vinst. Ett economusee kan bidra till att främja hantverkarnas status och bevara det immateriella kulturarvet genom att producera materiella produkter och genom att hantverkaren och konsumenten kommer i nära kontakt med varandra.

Stora delar av Norden karaktäriseras av småskaligt jordbruk med små ekonomiska marginaler. En avgörande fråga är därför hur dessa gårdars ekonomi kan stärkas genom en breddning av verksamheten inom områden som till exempel landskapsvård, mat, ridning, hälsorelaterade tjänster och uthyrning av rum. Diversifiering av verksamheter är en relevant fråga även inom andra traditionella näringar såsom småskaligt fiske. 
Exempel:

Valdres Natur- og Kulturpark, som är lokalt styrd, ska genom dess natur- och kulturarvstillgångar bidra till större värdeskapande och livskraft i området. En viktig strategi har varit att stoppa lantbrukets negativa utveckling genom att satsa på tilläggsnäringar i form av upplevelseturism och lokal förädling. Människan har länge känt till naturen som en positiv kraft för välmående och hälsa, vilket också kan vara en utmärkt affärsidé på hur man kan tjäna pengar.

Den internationella sammanslutningen av forskare och praktiker inom "Farming for health" använder landsbygdens och gårdarnas resurser, såsom djur, växter, trädgårdar och vardagliga rutiner, för att producera olika typer av sociala-, hälso- och utbildningstjänster. Det handlar om att på nya sätt dra nytta av gårdsmiljön och lantbrukarnas kunskaper.

Det finns ett behov av regelförbättringar för att minska den administrativa bördan för företagen som, om rätt genomfört, inte bör innebära en risk för felaktiga beslut. Framför allt är det nödvändigt med ett regelverk som är bättre anpassat till småskaliga verksamheter. Ofta återkommande är till exempel önskemålet om att få servera lokalproducerade matvaror i anslutning till mindre turistmål.

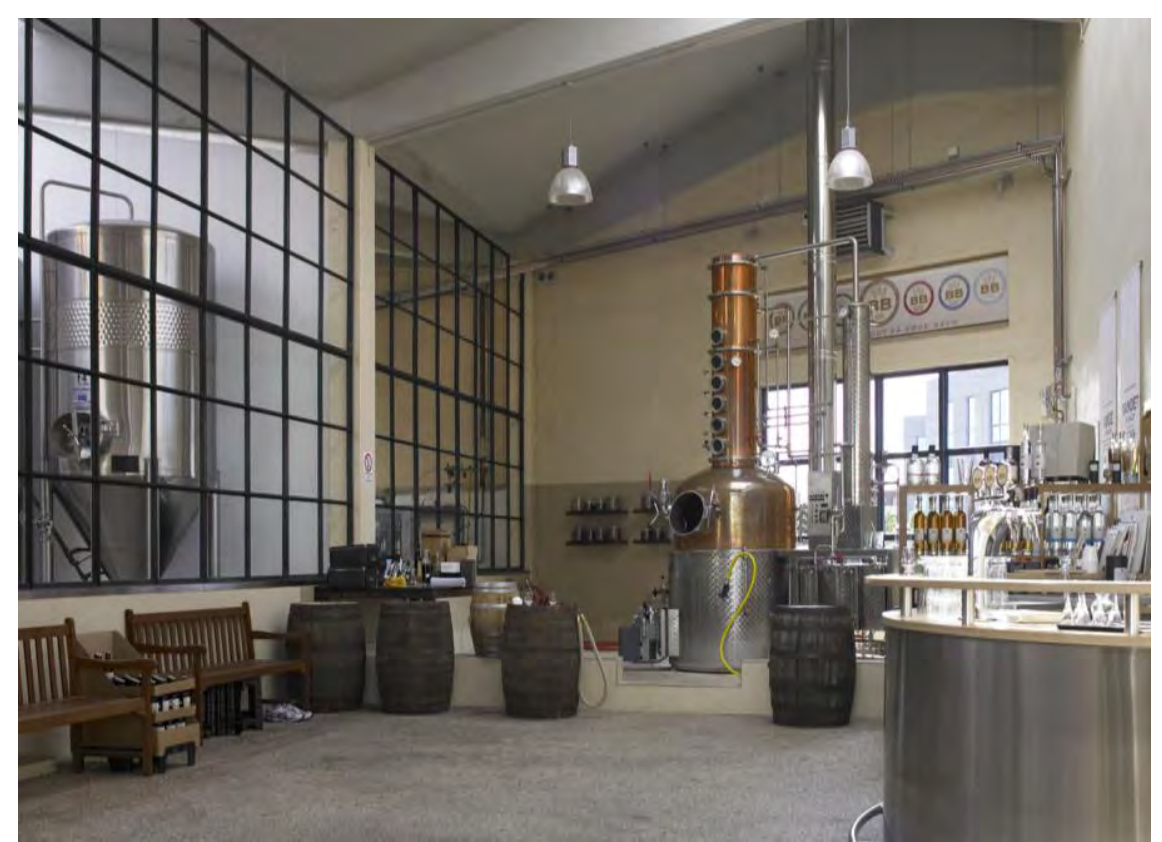

Bilden visar ett mikrobryggeri i Køge. Den småskaliga livsmedelsproduktionen och livsmedelsförädlingen har ofta en geografisk anknytning till lokal och regional identitet och platsers historia. Kopplingen mellan råvarans ursprung och landskapets natur- och kulturvärden kan förstärka produktens attraktionskraft genom det mervärde som det lokala utgör. Det blir en del av produktens identitet och präglar varumärket och marknadsföringen.

Foto: Ole Akhøj 


\section{Skapa "hållbar" uppföljning}

Många betraktar ekonomisk tillväxt som det viktigaste samhällsmålet. Emellertid upptäcker fler och fler att en ökad tillväxt av BNP är en otillräcklig indikator eftersom den inte ger en rättvis bild av välfärden och kan stimulera aktiviteter som inte är långsiktigt hållbara. Den tar inte hänsyn till inkomstfördelning, miljöförstöring, överdriven användning eller förslitning av naturresurser samt mycket annat som påverkar välfärden. Tvärtom, återställning av miljöskador ökar värdet av BNP.

Andra indikatorer och uppföljningsinstrument bör utvecklas och ges ett större utrymme. Hit hör gröna nyckeltal, välfärdsbokslut, miljö- och hälsokonsekvensbeskrivningar. Ett annat exempel är Genuine Progress Indicator (GPI) som tar hänsyn till de långvariga miljöskadorna av produktion och slitningen av naturens kapital.

\section{Från någon annans mun...}

Om platsmarknadsföring: "När det behövs - fungerar det inte! När det fungerar

- behövs det inte!"

Krister Olsson, Kungliga tekniska högskolan (SE)

"What is done locally, needs to have a global perspective, and global efforts need to be rooted in local and endogenous processes."

Per Ingvar Haukeland, Telemark Research Institute (NO)

"Having a small success is now helping us to have a big one."

Torsten B. Jakobsen, CEO the Læsø Foundation, Læsø Salt A/S and Læsø Kur Aps (DK)

"Cultural heritage can help to open the eyes of the people living their everyday lives in poor places. If anything has to change, it is not going to be changed by us, the people from Copenhagen. The change has to start by the people living in these regions."

Michael Lauenborg, Kulturarvsstyrelsen (DK) 



\section{Natur- och kulturarvsturism}

\subsection{Introduktion till tema och konferens}

Resor för människor samman och ökar kunskapen och förståelsen om skilda kulturer och livsvillkor. Turism är en växande bransch såväl globalt som i Norden. World Tourism Organisation (UNWTO) förutspår en global tillväxt av det internationella resandet med ca $60 \%$ fram till 2020 (Tillväxtverket 2010). Natur och kulturarv utgör här en central resurs. Detta erkännande ligger i de nordiska ländernas turiststrategier och är manifesterat i nationella så väl som internationella marknadsundersökningar. Detta innebär också stora utmaningar, bland annat kopplat till ökande tryck på natur och kulturarv på destinationer, krav på hållbara transporter för att minska klimatpåverkan och stimulera till ett miljövänligt utbud av varor och tjänster.

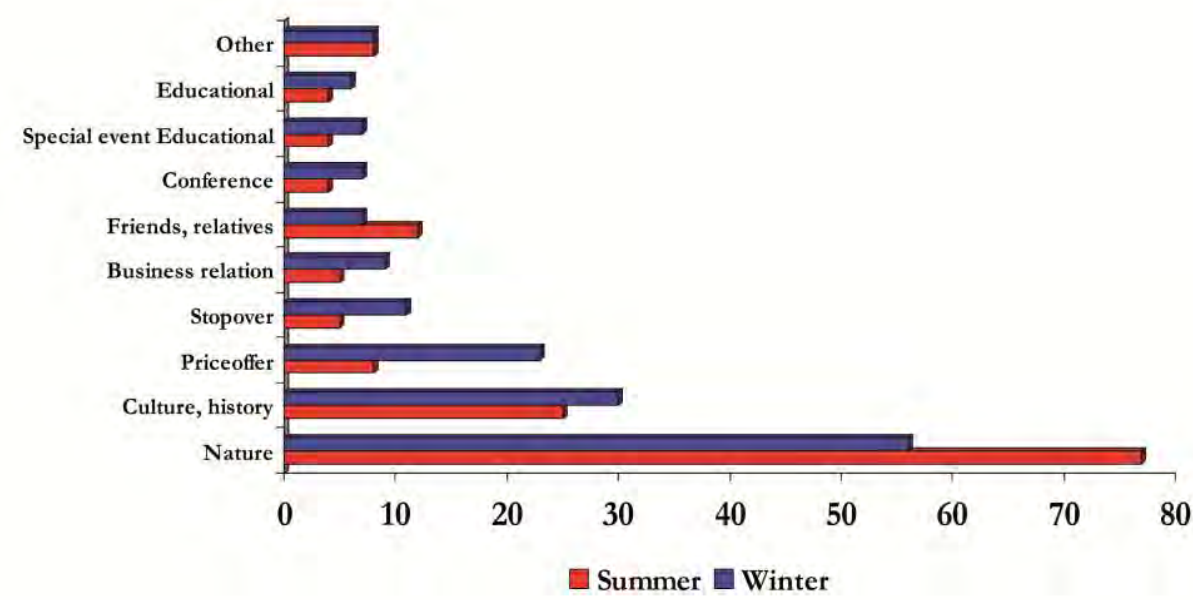

Diagrammet visar faktorer som påverkar människors beslut att besöka Island 2009. Natur (77\% sommar och $56 \%$ vinter) och kultur/historia (25\% sommar och 30 \% vinter) är de i särklass viktigaste skälen till att besöka landet. Liknande förhållanden gäller sannolikt även andra nordiska länder.

Källa: Islands Turistråd

Internationellt framstår Norden som ett exotiskt resmål, vars natur och kulturarv kan erbjuda speciella och unika upplevelser. Även om Norden har gott om "turistiska råvaror" kanske ännu fler besökare skulle lockas hit om länderna var bättre på produktutveckling? För att säkra att natur och kulturarv ska vara en varaktig och förstärkande faktor för turismutveckling är det viktigt att värdena betraktas både som resurs och produkt. Natur och kulturarv är upplevelseprodukter i sig. Men också resur- 
ser för utveckling av andra turismprodukter. Landskapet med sina natur- och kulturarvsvärden bör betraktas som en nödvändig infrastruktur för turismen. Samlat ger detta ett synsätt som understryker sammanhangen mellan kommersiella och kollektiva nyttigheter och främjar en hållbar utveckling.

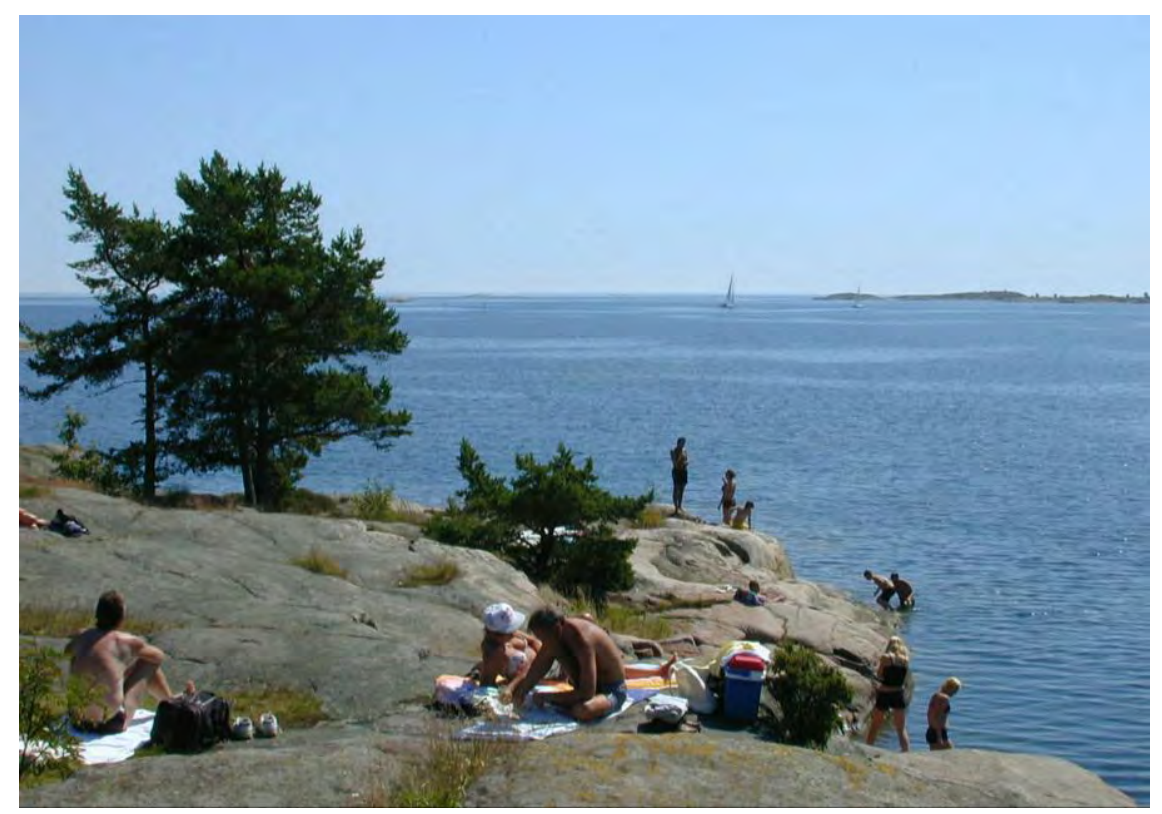

Vad är det som gör Norden till ett attraktivt resmål? En anledning är de karaktäristiska eller speciella landskapstyper som finns representerade i de olika länderna, exempelvis glaciärer, fjäll, fjordar, skärgårdar, småbrutna odlingsbygder och vidsträckta skogs- och sjölandskap.

Foto: Daniel Nilsson.

Medvetenhet om att samhälle, miljö och ekonomi ska beaktas och ses i sammanhang är på lång sikt en framgångsfaktor för turismnäringen som helhet samt för enskilda destinationer och turismföretag. Utveckling av turismnäringen i samklang med natur, kulturarv och lokalsamhälle är något som kräver tydlig styrning, men det är kanske inte alltid tydligt vem som har kontroll? Detta kan till stor del förklaras med att utveckling av hållbar turism är en komplex fråga som är beroende av samarbete mellan många olika aktörer, såsom nationella turistmyndigheter och natur- och kulturarvsmyndigheter, regionala myndigheter, lokalsamhällen, forskningsmiljöer och förstås turismnäringen själv.

Natur- och kulturarvsupplevelser blir större med ökad kunskap och förståelse. Det immateriella kulturarvet i form av traditioner och berättelser hjälper till att levandegöra landskapet. 


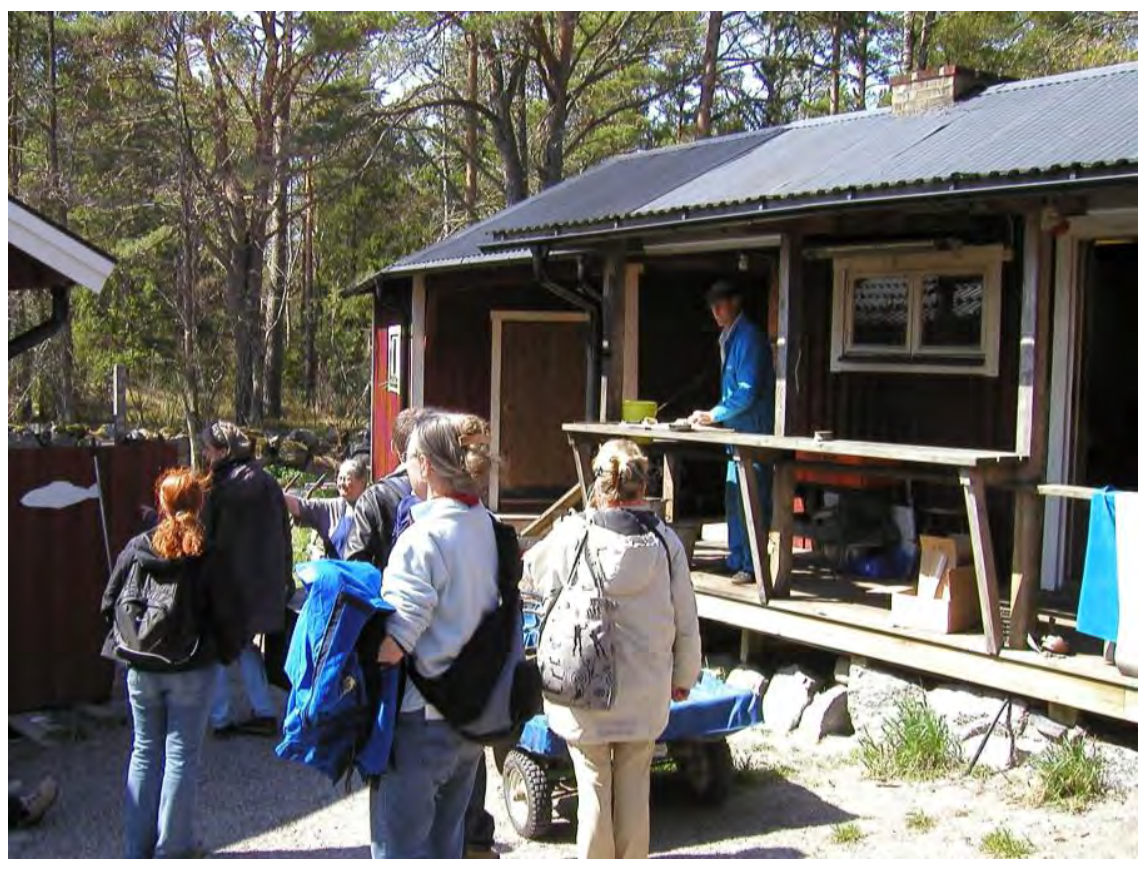

Nyfångad fisk som tillagas på lokalt vis av ett engagerande värdpar, allt inramat av en vacker skärgårdsmiljö, är här exempel på upplevelsekvaliteter.

Foto: Daniel Nilsson.

5.2 Konferens - Resa, bruka, bevara

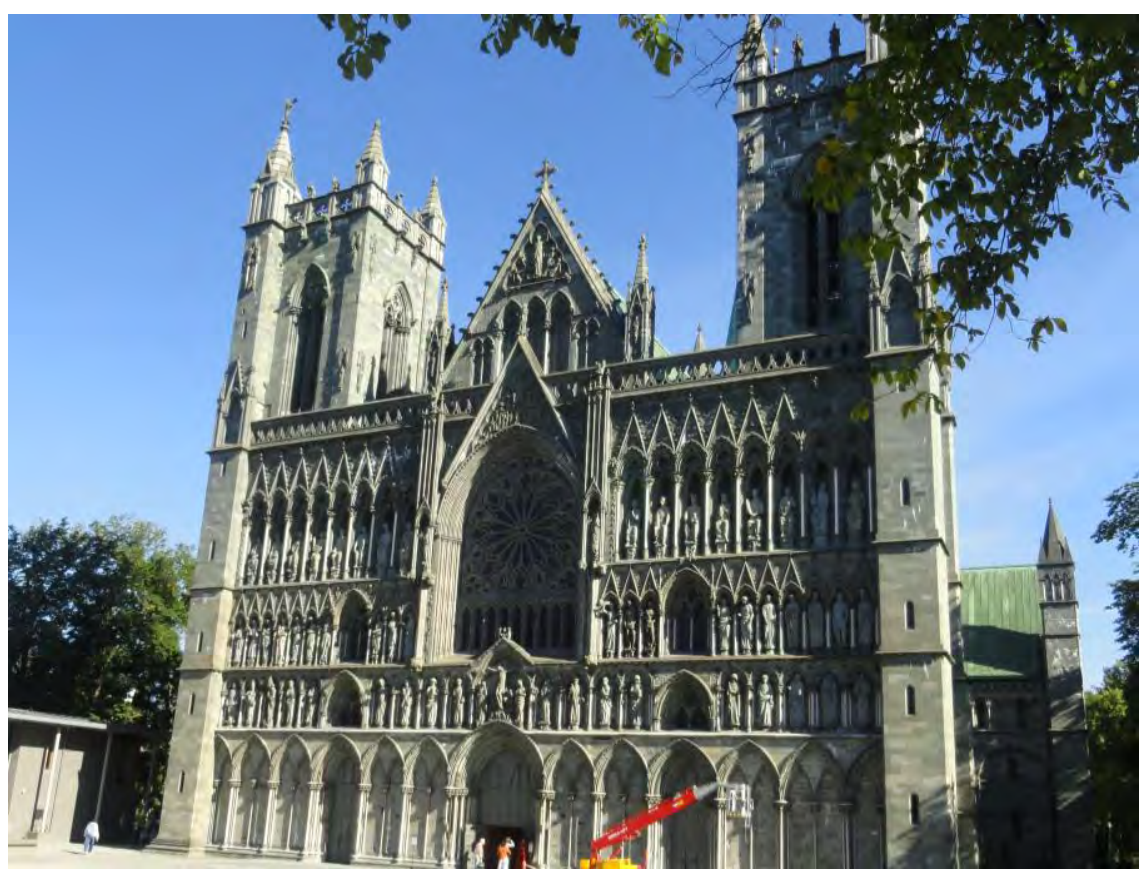

Nidarosdomen i Trondheim.

Foto: Daniel Nilsson. 
Konferensen i Trondheim fremhevet natur- og kulturarvsturisme fra flere vinkler:

- Turismens betydning for bærekraftig samfunnsutvikling

- Europeisk og nordisk perspektiv på bærekraftig turisme

- Bærekraftig turisme satt inn i en helhetlig politikk for regional- og lokalsamfunnsutvikling

- Formidling og guiding - merverdi gjennom innlevelse og forståelse

- Nettverkssamarbeid - optimalisering av markedsmuligheter

- Synergi og dilemmaer - bruk og vern

Nedenfor følger et utvalg av sentrale spørsmål, erfaringer og konklusjoner fra konferansen.

\section{Turismens betydning for bærekraftig samfunnsutvikling}

Gode strategier og prinsipper for hvordan man sikre kvalitet på tilbud og opplevelser, f eks ved sertifiseringsordninger for turismen har stor betydning for hvordan næringen utvikles. De nordiske lande har i varierende grad, og med forskjellige tilnærminger, arbeidet med å konkretisert hva bærekraftig turisme betyr i praksis. Å tydeliggjøre dette er en nødvendig del av en politikk for bærekraftig turisme. Her kan landene lære av hverandre. For eksempel har Norge ti prinsipper for bærekraftig turisme i sin nasjonale reiselivsstrategi, basert på UNWTO. I Finland har Forststyrelsen ni prinsipper for bærekraftig turisme innenfor de landområdene de forvalter.

Et overblikk over landenes reiselivsstrategier etterlater tvil om i hvilken grad de er forankret i og avstemt med Nordisk Ministrerråds strategi Hållbar utveckling - en ny kurs för Norden. Landenes turismemyndigheter vil ha nytte av sammen å se nærmere på sine respektive strategier, herunder på hvordan forholdet til natur og kulturarv er ivaretatt.

Bærekraftig turisme er avhengig av god koordinering mellom sektorer. For alle landene er dette en utfordring, og alle har et stykke igjen å gå. Hvert land må ta ansvar for å utvikle tydelige prinsipper og strategier for bærekraftig turisme. I dette arbeidet må turismemyndighetene trekke natur- og kulturarvssektoren med. Turisme-, natur- og kulturarvsmyndighetene bør gå sammen om konkrete prosjekter for å utvikle samarbeidet seg imellom. 


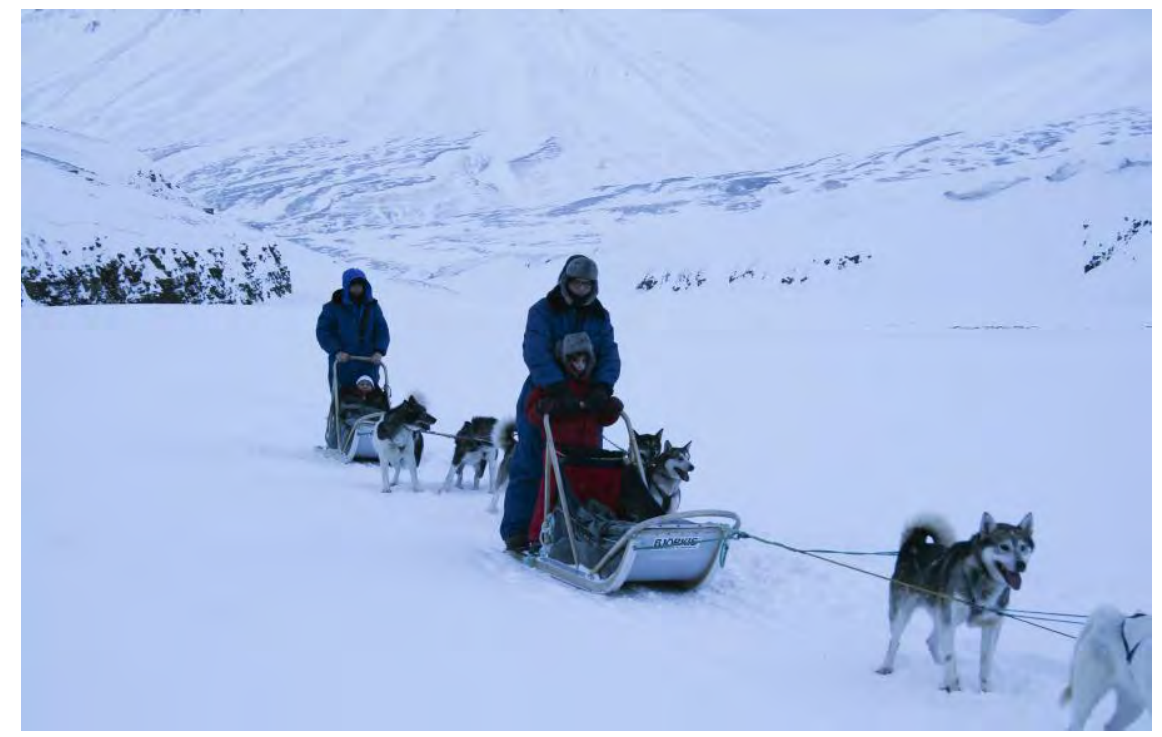

Med kunniga natur- och kulturarvsvägledare kan upplevelsen bli än större.

Foto: Marie Lier.

Flere av de nordiske landene arbeider med sertifiseringsordninger. Västra Götalandsregionen i Sverige utvikles f eks et sertifiseringssystem for destinasjoner etter inspirasjon fra Skotland. Island har valgt et system fra New Zealand (Qualmark). Norge prøver ut sertifiseringsordning for destinasjoner (Se bilaga om Resa, bruka bevara för mer information). Det er behov for gode sertifiseringssystemer både for destinasjoner og bedrifter. Særlig vil sertifisering på destinasjonsnivå kunne være et redskap for å integrere turismen i en bærekraftig samfunnsutvikling. En forutsetning for det er at sertifiseringsorningene ivaretar alle de tre bærekraftspilarene samfunn, miljø og økonomi.

Det er mange spørsmål knyttet til sertifiseringsordninger:

- Hvordan oppnå at hele verdikjeden i reiselivet utvikles i bærekraftig retning?

- Hvordan koble sertifisering til de valg kunden gjør, slik at kunden velger bærekraftige alternativ?

- Skal sertifisering være et myndighetsansvar eller noe reiselivsnæringen håndterer?

Exempel:

Naturens Bästa er eksempel på en sertifiseringsordning som både setter krav til hele foretaket (bedriften) og spesifikke krav til produkter og tjenester. Denne sertifiseringsordningen for økoturismebedrifter i Sverige har et sett kriterier som blant annet omfatter kommersialisering, lokal forankring, natur- og kulturvern, vertskapsrollen og krav til gjesten. 
Det kan ligge stor nytte i å utveksle kunnskap mellom de nordiske landene om utvikling av bærekraftig turisme basert på konkrete erfaringer.

\section{Destinasjonsutvikling må gå hånd i hånd med bærekraftig utvikling av lokalsamfunn og regioner}

Destinasjonsutvikling må baseres på lokalt forankret kunnskap, forståelse og bevisstgjøring om hvilke verdier stedet og regionen har. Det tydeliggjør destinasjonens særpreg - hvilke kvaliteter som skiller den fra andre destinasjoner. Klare verdier, tydelig avgrensning av destinasjonen og sterke aktører er viktige faktorer for god destinasjonsutvikling.

\section{Exempel:}

Danmarks erfaringer med å definere «opplevelsesrom» er relevante her. Man har arbeidet lokalt med borgere, næringsliv, politikere og embetsmenn om hva som karakteriserer stedet der natur, kulturarv, turisme og opplevelser møtes.

En annen betingelse er forpliktende avtaler og partnerskap mellom aktører på destinasjonen - både næringsliv, myndigheter, forskningsmiljøer og frivillig sektor. Regionale natur- og kulturparker kan være rammer for slike partnerskap. Nærøyfjorden Verdsarvpark i Norge er et eksempel. Turisme-, natur- og kulturarvsmyndighetene bør engasjere seg i utviklingen av slike partnerskap.

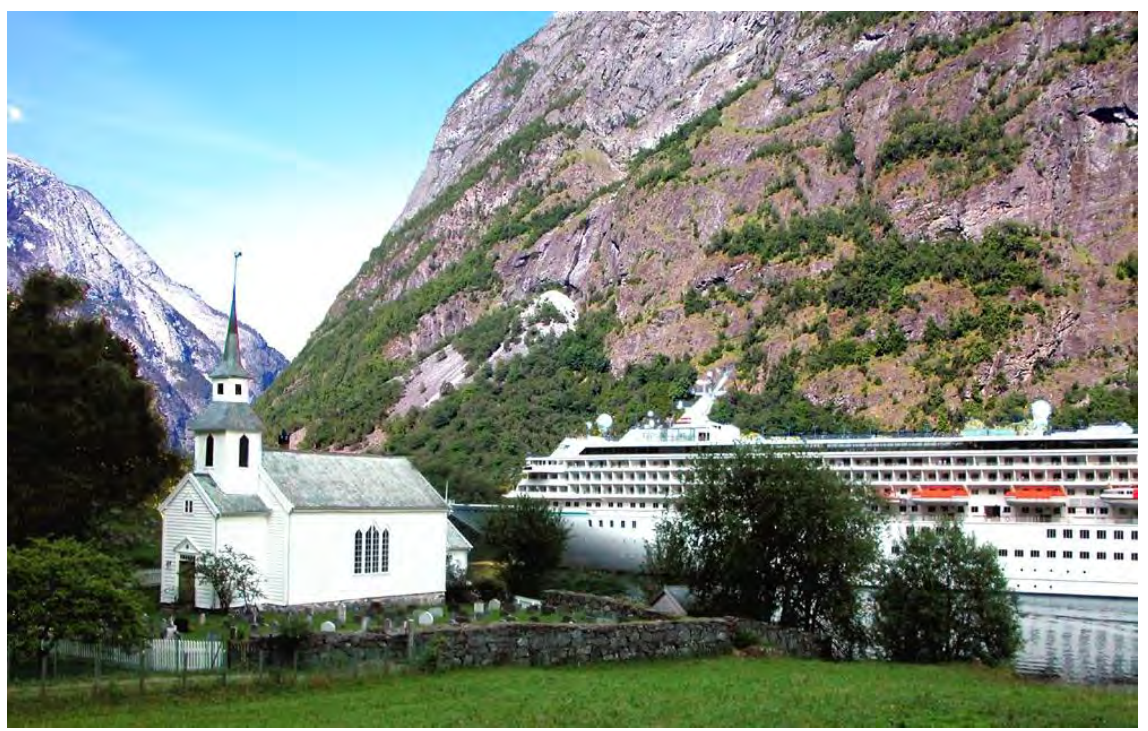

Strategisk destinationsutveckling som bygger på natur och kulturarv behöver utvecklas. Det är även av stor vikt att lokalsamhället får ta del av vinster som storskaliga turismaktörer genererar. På vilka sätt kan lokalsamhället bli en leverantör till näringslivet av varor och tjänster?

Foto: Thor Andersen 
Lokalsamfunnene må se betydningen av god helhetlig planlegging. Dette er i første rekke kommunenes ansvar. Et sentralt perspektiv i planleggingen bør være: Steder som er gode å bo, arbeide og leve i vil ha de beste forutsetninger for å være et gode reisemål på lang sikt.

\section{Nettverkssmarbeid og kompetanseutvikling}

Bærekraftig turisme krever kunnskap og kompetanse. Turismenæringen og turismemyndighetene må forstå hva som skal til for at natur- og kulturarvsverdier skal bevares og utvikles, slik at det kan være varige ressurser for næringen. Det er også behov for mer kunnskap om forretningsmuligheter, innovasjon og entreprenørskap knyttet til natur- og kulturarvsturisme i en bransje som er preget av mange små og nisjepregete bedrifter.

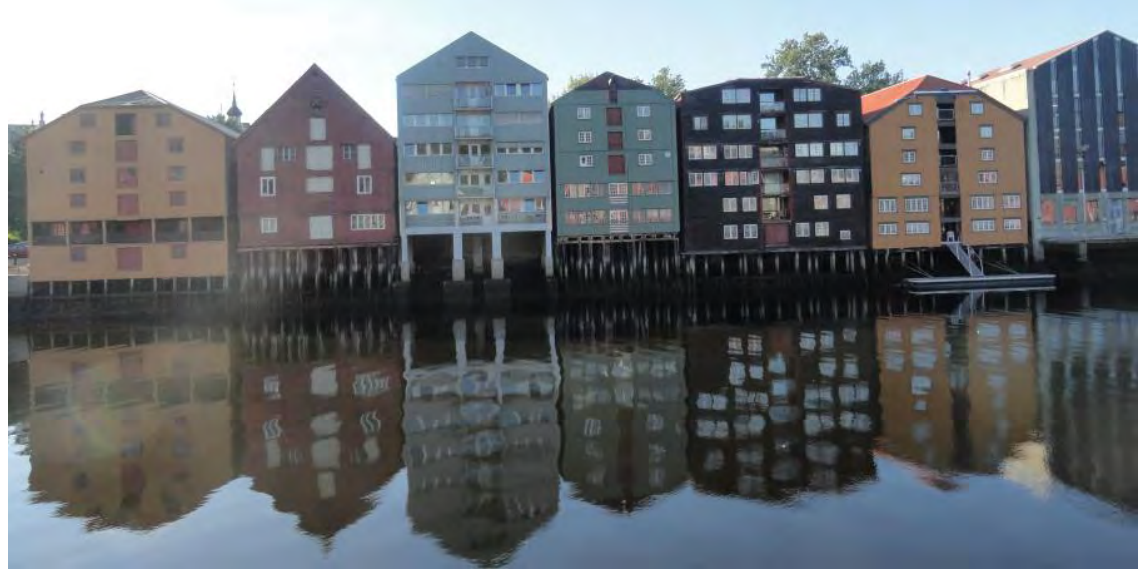

Natur och kulturarv är viktiga delar av en stads attraktionskraft. Vid älven $i$ Trondheim har nutida bebyggelse anpassats efter traditionellt formspråk $i$ de gamla packhuskvarteren.

Foto: Daniel Nilsson

I møtet med turistene er innbyggerne i lokalsamfunnene vertskap. Denne erkjennelsen bør få konsekvenser for lokal forankring av reiselivet, blant annet samarbeid med annet næringsliv, foreninger og skoler. I dette bør inngå en grunnleggende oppbygging av kompetanse om naturog kulturforhold lokalt.

Natur- og kulturarvsmyndighetene må på sin side utvikle forståelsen for næringens krav til markedstilpasning og lønnsomhet. Avstanden mellom sektormyndigheter, næring og lokalsamfunn må kortes ned for at samhandlingen skal bli effektiv og resultatene gode. 
Exempel:

Prosjektet Innovativ fjellturisme er et eksempel på nettverk mellom kommuner, destinasjonsselskaper, bedrifter og forskningsmiljøer i en fjellregion i Norge. Prosjektet har blant annet arbeidet med innovasjon i bedriftene, planleggingsmodeller for lokalsamfunnene og modeller for finansiering av fellesgoder.

\section{Formidling og guiding}

Formidling av natur- og kulturarv som ledd opplevelsesprodukter, er i rivende utvikling ettersom teknologien åpner muligheter. Det gir nye muligheter for å utvikle attraktive museer, informasjons- og opplevelsessentra. For mange bedrifter og destinasjoner er potensialet for å nå den enkelte reisende via internett, mobil og andre kanaler og plattformer særlig interessant.

\section{Exempel:}

Prosjektet 1001 fortellinger om Danmark (www.1001fortellinger.dk) formidler historie, opplevelsesmuligheter, synliggjør kulturarven som ressurs for utvikling, og aktiviserer lokalbefolkningens viten om landskap og kulturarv. Utradisjonelle deler av naturen og kulturarven tas i bruk i reiselivet. Nordic Blue Parks som ledes av Finland, «åpner» undervannslandskapet ved å legge tilrette for opplevelse av skipsvrak. Industriarv, pilegrimstradisjoner og ulike former for dyresafarier er andre eksempler på natur- og kulturarvsturisme som på fremmarsj i Norden

Likevel vil nok det det personlige møtet med en vert kan være mer avgjørende for utbyttet til den reisende enn teknologiske løsninger. Kompetansen hos vertskapet er en viktig faktor. Men de nordiske landene mangler gjennomgående en systematisk vertskaps- og guideutdanning. 


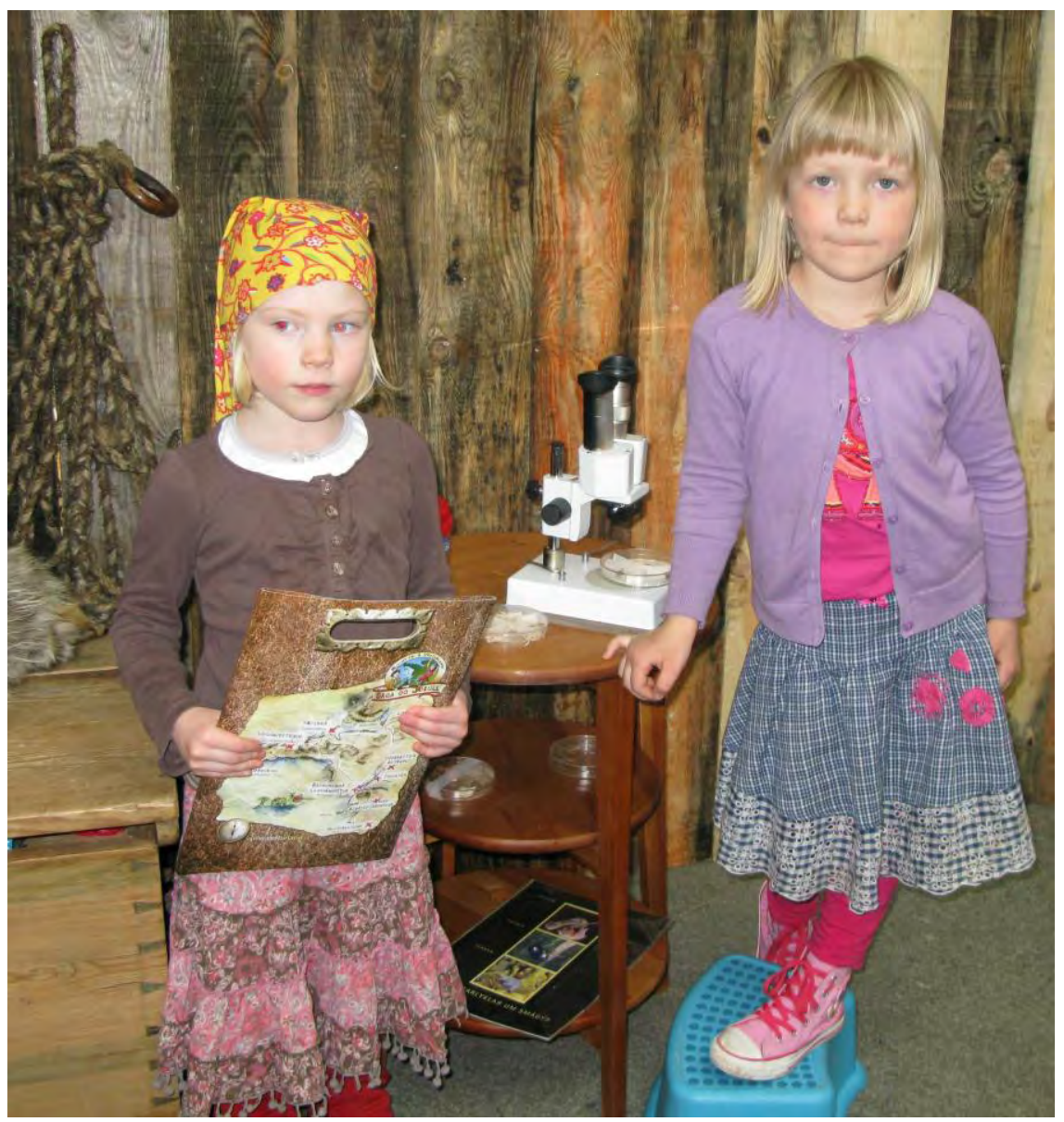

I det isländska projektet Saga og Jøkull har tio turismföretag satsat på upplevelser för barn och deras familjer, byggt på natur och kultur. Kvaliteten ligger här $i$ den kreativa förmedlingen och aktiviseringen av deltagarna.

Foto: Guđbjörg Gunnarsdóttir.

Natur- og kulturarvssektorene er leverandører av innhold til opplevelsesprodukter og har selv interesse av at verdiene i naturen og kulturarven formidles. Det bør ligge vel til rette for samarbeid og felles prosjekter med turismenæring og myndigher, og med museer og andre med kompetanse på formidling. 


\section{Från någon annans mun...}

"Turism är en kommersiell näring som måste anpassa sig till samhället" Bjørn M. Bjerke, NHO Reiseliv (NO)

"Sustainability is the only way"

Elias Bj Gislason, Icelandic Tourist Board (IS)

"Det goda reselivet är även det goda boendelivet"

Ivar Bjarne, Nærøyfjorden Verdsarvpark (NO)

"See each place from their own perspective"

Peter Kvistgaard, Aalborg Universitet (DK)

"Bristen på lönsamhet är det största hindret i branschen"

Per Jiborn, Naturens Bästa (SE)

"The more you know the more you care"

Mari Salminen, Museiverket (FI) 


\section{Natur- och kulturarvskraft 2010}

Hur tar vi i Norden tillvara på naturens och kulturarvets potential i arbetet med hållbar utveckling och tillväxt? Vilka är de strategiska vägvalen och vad krävs för att berörda aktörer ska gå från ord till gemensam handlingskraft?

Natur och kulturarv utgör en resurs för Nordens utveckling, tillväxt och konkurrenskraft och är en gemensam angelägenhet för många aktörer. Men hur kan denna kraft omvandlas till framgångsrika gemensamma samarbeten i framtiden? Detta var utgångspunkter för den nordiska workshopen Natur- och kulturarvskraft 2010 som ingick i den sista och sammanfattande delen av projektet. Arrangemanget utgick från resultaten i de tidigare etapperna och hade som målsättningar att förankra och få feedback på projektresultaten, få fram förslag på hur viktiga frågor ska utvecklas och skapa nätverk för att kunna genomföra ovanstående förslag.

Deltagare på workshopen var beslutsfattare, andra nyckelpersoner från myndigheter och organisationer och forskare som arbetar med natur och kulturarv som resurs för hållbar utveckling och tillväxt.

Gruppdiskussionerna syftade bland annat till att dela tankar och erfarenheter om vilka som är de stora möjligheterna och utmaningarna $\mathrm{i}$ arbetet med natur och kulturarv som resurser för hållbar utveckling och tillväxt i Norden. På workshopen användes en teknisk lösning för att stödja interaktivitet och dialog. Det handlade om att under kort tid locka fram kreativa och intressanta idéer och sedan göra gemensamma prioriteringar av dessa.

Grupperna på workshopen betonade särskilt vikten av samarbete över sektorsgränser och mellan olika samhällsnivåer samt vikten av förankring och delaktighet i lokalsamhället. Det stod klart att projektet som helhet har lyckats med att identifiera centrala utmaningar och möjligheter. Påfallande många problem och möjligheter är likartade mellan länderna och det finns mycket att lära av varandra, samtidigt som man måste vara uppmärksam på skillnader (till exempel i allemansrättens ställning, myndighetsstrukturer, markägarstrukturer, med mera). Men kännedom om viktiga problem och möjligheter är bara början. I nationella grupper diskuterades därför konkreta handlingsvägar - vilka som är de viktigaste insatserna och vad som krävs av deltagande myndigheter och organisationer för att genomföra några av dessa föreslagna åtgärder. Projektet fick in cirka 70 förslag på insatser för hur de nationella arbe- 
tena med natur och kulturarv som resurs för hållbar utveckling och tillväxt kan utvecklas, av vilka flera också är relevanta på en nordisk nivå.

Projektet har haft som målsättning att stärka natur och kulturarv som utvecklings- och tillväxtfaktorer i samhället. Det var därför glädjande att många av deltagarna menade att workshopen gav inspiration och idéer till nya projekt och avsåg att ta med frågor och följa upp diskussionen inom och mellan länderna. Projektet har därmed bidragit till att skapa en ökad handlingskraft inom området.

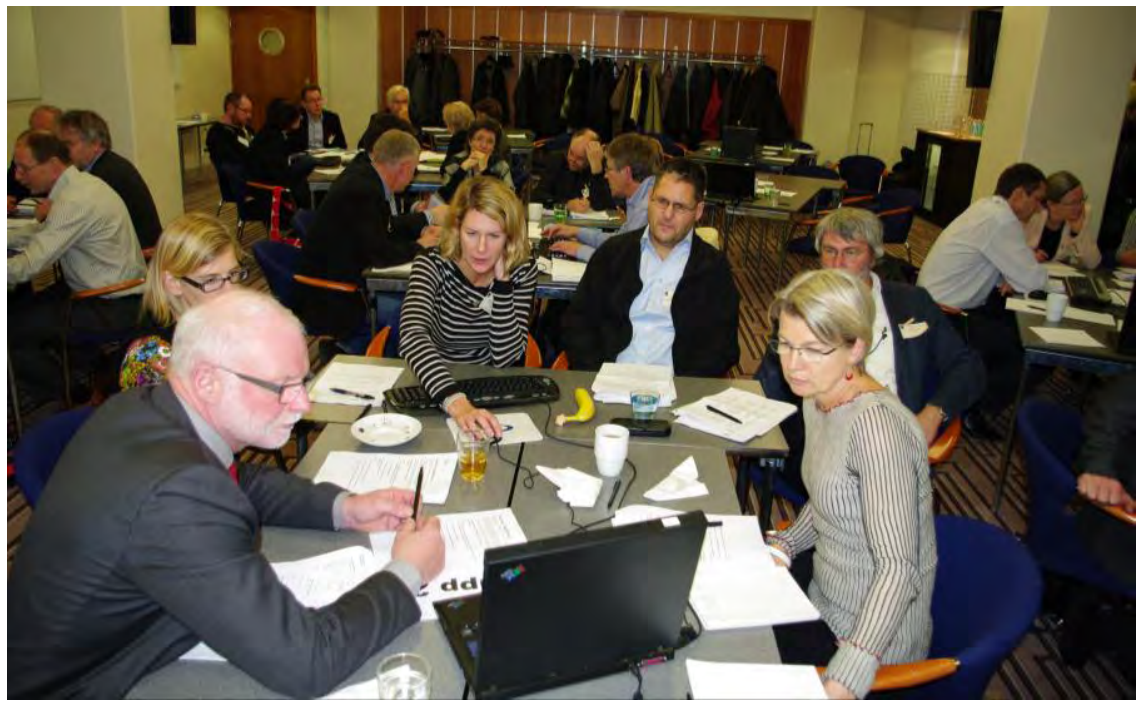

Grupparbetet i full gång på workshopen.

Foto: Helgi Michelsen.

Baserat på materialet från workshopen följer nedan utmaningar och rekommendationer som detta projekt ser som intressanta att lyfta fram utifrån en nordisk kontext.

\subsection{Utmaningar och rekommendationer}

\section{Utveckla tvärsektoriell samverkan mellan berörda politikområden}

\section{Varför?}

En mer samordnad stat avseende mål, styrmedel och åtgärder samt med en tydlig och klar ansvarsfördelning sinsemellan kan underlätta för medborgare, kommuner, privata intressen och andra aktörer att få information och stöd. Genom en utvecklad samverkan kan t.ex. administrativa hinder för mellansektoriella frågor minskas. För att få till stånd ett samarbete över sektorsgränser krävs ofta någon form av förpliktande 
faktor samtidigt som det också är viktigt att förtjänsterna med samverkan identifieras inom berörda verksamhetsområden.

\section{Rekommendationer}

Nationell politisk nivå:

- Ge gemensamma uppdrag till myndigheter på nationell och regional nivå för att utveckla arbetet med natur och kulturarv som resurs för hållbar utveckling och tillväxt.

Nationella och regionala myndigheter:

- Identifiera och analysera faktorer som underlättar respektive försvårar tvärsektoriell samverkan samt åtgärda hinder

- Formalisera samverkan genom t.ex. samarbetsavtal, gemensamma handlingsplaner och/eller gemensamt finansierade program som löper över längre tidsperioder

- Anordna mötesplatser för såväl horisontell som vertikal sektorsövergripande samverkan

- Undersök möjligheter till ökad samfinansiering nationellt och på nordisk nivå

- Skapa bättre koordinering mellan olika sektorers digitala tjänster och hemsidor

\section{Natur- och kulturarvsförvaltningar behöver utveckla sin roll som dialogpartner}

\section{Varför?}

Dialog kan fungera som ett redskap för att överbrygga olika sektorsintressen. Genom en utvecklad roll som dialogpartner kan myndigheterna fungera som katalysatorer för regionala och lokala initiativ. Det handlar också om att tillvarata engagemang och kunskap i lokalsamhället samt stärka det lokala ägarskapet i projekt och verksamheter som baseras på natur och kulturarv.

\section{Rekommendationer}

Nationella och regionala myndigheter samt kommuner:

- Utveckla kompetens för att samverka och länka samman aktörer på olika nivåer

- Utveckla kompetens inom metoder för dialog och delaktighet

- Fortsätt att utveckla och tillämpa sociala medier för kommunikation med medborgarna 


\section{Stimulera natur- och kulturarvsföretagande}

\section{Varför?}

En hållbar tillväxt kräver nya kreativa lösningar och att balanserade avvägningar görs mellan ekonomiska, sociala och miljömässiga effekter. Det finns en stor potential för företagande på natur- och kulturarvsgrund. Ett utvecklat företagande inom området leder även till att det skapas en breddad efterfrågan på natur- och kulturarvskompetens.

\section{Rekommendationer}

Nationella myndigheter:

- Utred ekonomiska incitament för att främja utvecklat och hållbart företagande baserat på natur- och kulturarvsgrund.

- Stimulera innovativa miljöer över sektors-, lands- och länsgränser.

- Informera om möjligheter för företagande på natur- och kulturarvsgrund och sprid goda exempel.

- Ta fram modeller för kompetensutveckling om naturens och kulturarvets betydelse för hållbar utveckling och tillväxt som kan anpassas till olika aktörer.

Nationella, regionala och lokala myndigheter:

- Initiera fler samarbeten mellan offentliga, privata, civila och akademiska aktörer

- Utveckla strategier för förvaltning och nyttjande av skyddade områden och miljöer som beaktar det rörliga friluftslivet och turismnäringen.

- Långsiktig områdesplanering för en ökad förutsägbarhet vad gäller turismnäringens arealbehov.

- Rådgivning och vägledning till entreprenörer och företag som är engagerade i och använder natur och kulturarv.

- Tillämpa och utveckla principer och kvalitetssäkringssystem för att säkra hållbarhet och gynna lönsam affärsutveckling.

\section{Samordna forskning}

\section{Varför?}

Det finns behov av att fortsatt utveckla tvärvetenskaplig kunskap och angreppssätt i relation till projektets teman och frågeställningar. Detta kan bland annat bidra till en förbättrad gemensam förståelse för naturens och kulturarvets betydelse för utveckling och tillväxt.

\section{Rekommendationer}

Nationella myndigheter, forskningsråd, universitet och högskolor: 
- Fortsatta systematiska analyser om natur och kulturarvets ekonomiska och sociala betydelser behövs. Forskning pågår och har genomförts inom området, men det saknas en överblick och sammanvägda slutsatser. Det behövs en strategisk sammanfattning av vilken forskning som har bedrivits, vad den har gett för resultat och vilka behov som finns. 



\section{Förslag till fortsatt nordiskt samarbete}

Några av de resultat, erfarenheter, identifierade behov och förslag till åtgärder som framkommit genom detta projekt föreslås vara utgångspunkter och testas i ett fortsatt nordiskt samarbete. Här presenteras några idéer och ramar för detta som sedan behöver fördjupas, konkretiseras och förankras. De kan bland annat vara underlag för att ta fram nya projektansökningar till Nordiska ministerrådet.

\subsection{Projekt - erfarenhetsutbyte mellan nordiska landskap (regioner/lokalsamhällen)}

Denna rapport visar den mångfald av processer, metoder och tillvägagångssätt för hur natur och kulturarv kan tas i bruk för en hållbar utveckling och tillväxt. Projektet har bland annat konstaterat att tvärsektoriell samverkan och dialog med lokala och regionala aktörer som arbetar med utvecklings- och tillväxtfrågor behöver utvecklas. Arenan bör anpassas efter vilka aktörer som medverkar, vilka samhällsfrågor som står på agendan och det landskap i vilket samarbetet äger rum. Samtidigt finns det grundläggande förutsättningar som bör vara uppfyllda och kunskaper som är generellt applicerbara för en framgångsrik samverkan.

Projektgruppen föreslår att Nordiska ministerrådet ger förutsättningar för erfarenhetsutbyte mellan ett urval av nordiska landskap (regioner/lokalsamhällen) som arbetar tvärsektoriellt med natur och kulturarv som resurser för utveckling och tillväxt. Projektet föreslås omfatta såväl nationell, regional och/eller lokal förvaltningsnivå och kommer att leda till uppkomsten av tre tillfälliga och informella nordiska nätverk. Myndigheter inom natur, kulturarv, utveckling och tillväxt kan genom att gemensamt engagera sig i ett antal konkreta fall öka kunskapen om hur de på bästa sätt kan bidra praktiskt på de tvärsektoriella regionala och lokala arenorna.

Urvalet av områden bör utgå från likartade landskap och parallella samhällsutmaningar för att:

- göra det enklare att identifiera gemensamma problemställningar

- kunna göra relevanta jämförelser mellan områden

- få en gemensam grund för att diskutera valmöjligheter inför framtiden 
De övergripande målen för projektförslaget kan sammanfattas enligt följande:

- Främja utvecklingskraft utifrån regionala eller lokala förutsättningar

- Ge de utvalda områdena en nordisk arena för att diskutera viktiga samhällsfrågor relaterat till natur och kulturarv som centrala framtidsresurser

- Analysera best practice för en samordnad statlig involvering $\mathrm{i}$ samhällsutvecklingsprocesser

- Ge rekommendationer för anpassning av myndigheternas arbete inom detta fält

- Göra fördjupade analyser om hur natur och kulturarv kan användas som utvecklingskraft relaterat till rådande samhällsutmaningar och landskapens kulturella, miljömässiga, ekonomiska och sociala resurser

Projektgruppen föreslår att urvalet av områden sker utifrån följande landskapstyper:

- Kust- och skärgårdslandskap

- Urbana landskap med "gröna" tillgångar

- Landsbygd (fjäll-, odlings- och/eller skogslandskap)

Förslaget är att börja med en landskapstyp och ett nätverk för att samla erfarenheter innan de andra nätverken etableras. Som utgångspunkt bör det bara väljas en region från respektive land inom varje landskapstyp. De utvalda områdena bör företrädesvis ha igångsatt eller planlagt projekt som med ett tvärsektoriellt angreppssätt försöker använda natur och kulturarv som resurs för utveckling och tillväxt.

En projektgrupp med representanter från nationella myndigheter inom områdena natur, kulturarv, utveckling och tillväxt föreslås ansvara för val av områden och koordinering av ramprojektet. Projektet bör resultera i en avslutande NMR-rapport med en sammanfattande analys av best practise. Ett utkast till en sådan rapport bör diskuteras på en avslutande workshop med representanter från alla utvalda regioner och central myndighetsnivå.

Hur projektet i detalj bör genomföras får utredas närmare, antagligen är det bästa att dela upp det i delprojekt över en period på tre till fyra år. Det kan vara aktuellt att NMR/TEG söker samarbete med andra organ om utformning och finansiering av projektet. 


\subsection{Projekt - principer för hållbar turism}

De nordiska länderna arbetar alla med principer för hållbar turism, men de gör det i stort sett var för sig. Detta projekt har identifierat ett behov av kunskapsutveckling och kompetenshöjning samt en bättre samordning inom området. En fördjupad genomgång bör göras av var de nordiska länderna står i dag, var de har sina styrkor och var det finns behov av utveckling och kompetenshöjning. Detta gäller både på verksamhetsnivå och för turistdestinationer.

Detta kan utgöra grund för rekommendationer om gemensamma nordiska principer. Projektet ska behandla hållbar turism i bred bemärkelse - från den ensamma fjällvandrande familjen till massturism i sommarhusområden.

Deltagare i projektet bör vara natur- och kulturarvsmyndigheter, nationella turismmyndigheter, regionala och lokala myndigheter som arbetar med turism samt branschorganisationer inom näringen.

NMR/TEG bör även i det här fallet överväga att söka samarbete med andra organ om finansiering och utformning.

\subsection{Projekt - metoder för ekonomisk värdering av natur- och kulturmiljöer}

Naturen och kulturarvet spelar en tydlig och viktig roll för de nordiska ländernas ekonomier. De är en viktig drivkraft för turismen, men den samhällsekonomiska betydelsen av natur och kulturarv sträcker sig utöver detta. Investeringar i natur och kulturarv kan främja ekonomin genom att attrahera nya företag och invånare och uppmuntra människor att köpa mer lokalt. I dagens samhälle blir det allt viktigare att sätta marknadspris på saker och ting. Genom att använda ekonomiska analyser kan natur- och kulturmiljösektorerna bland annat bättre kommunicera med omvärlden och förklara värden inom sitt område. I de nordiska länderna har några försök gjorts att värdera de ekonomiska fördelarna med skydd och bevarande av natur och kulturarv, framför allt inom naturvårdsområdet. Olika metoder bär på sina styrkor respektive svagheter.

Inledningsvis finns det ett behov att sammanställa och analysera forskning och metoder för ekonomisk värdering av natur- och kulturmiljöer för att etablera en gemensam grundförståelse inom ämnesområdet. I nästa fas föreslås att värdering av naturens och kulturarvets ekonomiska betydelse genomförs, enligt jämförbara metoder, på 2-4 platser i varje nordiskt land.

Deltagare i projektet bör vara natur- och kulturarvsmyndigheter i Norden i samarbete med universitet/högskolor med kunskaper inom området. 



\section{Referenser}

Council of Europe (2000): European Landscape Convention CETS No.: 176. http://conventions.coe.int/Treaty/Commun/QueVoulezVous.asp?NT=176\&CM=8 $\& \mathrm{DF}=5 / 19 / 2009 \& \mathrm{CL}=\mathrm{ENG}$.

Healey, P. (1998): Collaborative Planning in a Stakeholder Society. The Town Planning review, vol 69, no 1, 1-21.

Healey, P. (2009): In Search of the "Strategy" in Spatial Strategy Making. Planning Theory \& practice, vol 10, no 4, 439-457.

Kristensen, L. Artikel (2010): Den goda vardagen. Nordisk konferens om natur och kulturarv som resurs för god livsmiljö. Det Biovidenskabelige Fakultet, Skov og Landskab.

Kulturarvsstyrelsen og Realdania (2005): Kulturarv en væsentlig ressource for kommunernes udvikling. En analyse af danskernes holdninger til kulturarv.

Kvernberg, R (2010): Resa, bruka, bevara. Nordisk konferense Natur-og kulturarv som ressurs för bärkraftig turistutvikling. Trondheim 6-7 september 2010. Oppsummering med fokus på utfordringer og mulige tiltak. Re Plan på oppdrag av Riksantikvaren og Direktoriatet for Naturforvaltning. 2010.

Møller Christensen, S \& Guldberg, M (2004): Historisk kystkultur - En ressource $i$ nutiden. Nordiska ministerrådet. Nord 2004:6.

Nilsson D. \& Hulusjö N. (2009): Kulturarv och natur som resurs för hållbar utveckling och tillväxt. Nordisk översikt. TemaNord 2009:513. Nordiska ministerrådet.

Nordiska ministerrådet (2009): Hållbar utveckling - En ny kurs för Norden. Reviderad utgåva med mål och prioriteringar 2009-2012. ANP 2009:726.

Nordiska ministerrådet (2008): Miljöhandlingsprogram 2009-2012. ANP 2008:733.

Tillväxtverket (2010): Fakta om svensk turism. Turismens effekter på ekonomi och sysselsättning samt volymer, beteenden, utbud och efterfrågan. 



\section{Bilaga}

\section{Föredrag i sammanfattning}

\subsection{Den goda vardagen}

Nordisk konferens om natur och kulturarv som resurs för god livsmiljö

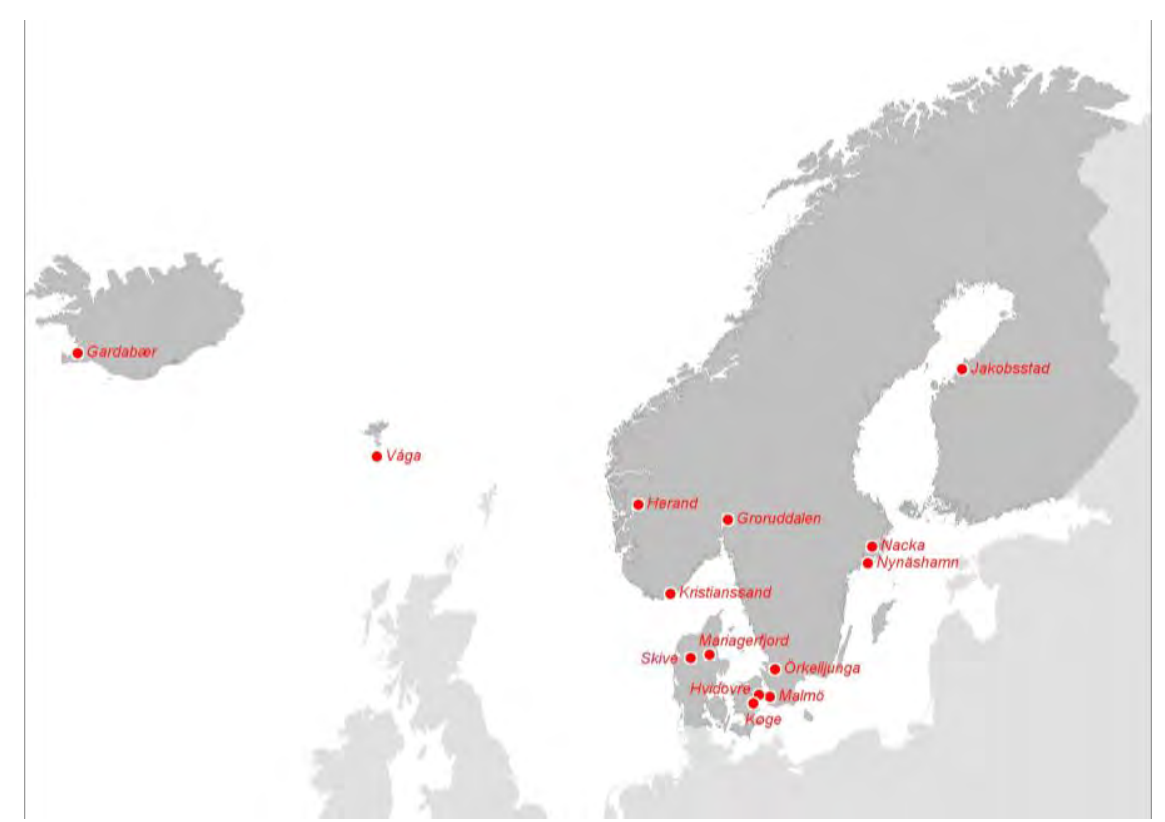

Sammanställt av Lone Kristensen, lektor ved Københavns Universitet, Det Biovidenskabelige Fakultet, Skov og Landskab, juni 2010

\subsubsection{Natur og kulturarv som element i udvikling af byidentitet og byfornyelse}

Projekterne beskrevet under denne titel er forskellige i udgangspunkt og formål, men har det til fælles, at de alle handler om udvikling af byens identitet gennem styrkelse af natur og kulturarven. Hovedparten af projekterne har indbefattet mere eller mindre komplekse samarbejdsformer, hvor både kommunale og statslige myndigheder har været involveret lige som samarbejde på tværs af fagmiljøer har spillet en væsentlig rolle. Borgerinddragelse har været brugt i varierende grad. 


\subsubsection{Langsigtet arbejde med historiske fri-/naturområder komplementerer bygningsbevaringen og styrker byens identitet/image}

Stadsplanarkitekt Ilmari Heinonen, Jakobstads planläggningsavdelning (FI)

Jakobsstad er en by med 20.000 indbyggere beliggende ved den botniske bugt. Byen kendetegnes dels af sin bygningskulturarv som består af 70 beskyttede bygninger, hvoraf de ældste er fra 1700 tallet og de yngste fra 1900 tallet, dels af sin "grønne kulturarv“ bestående af haver, parker og andre rekreative områder. Allerede i byplanen fra 1901 spillede parker og plantninger en central rolle i det målet var skabe et netværk af offentligt tilgængelige grønne anlæg i byen.

Restaurering af disse anlæg fik en fornyet interesse i begyndelse af 2000 , hvor man bl.a. med baggrund i gamle registreringer suppleret af arkæologiske undersøgelser har restaureret Aspegrens Trädgård. Haven blev oprindeligt blev anlagt 1770'erne af præsten Gabriel Aspegren i tilknytning til en nybygget præstegård. Gabriel Aspegren arbejdede aktivt for at effektivisere jord- og havebruget, og haven indgik i dette udviklingsarbejde. Haven ejes i dag af en stiftelse og drives af en støtteforening. I forbindelse med havens renovering blev der blevet åbnet en cafe og haven er i dag en vigtig identitetsskaber for byen og er blevet et stort og populært udflugtsmål.

\subsubsection{Kulturarv 2650, på sporet af forstadens velfærdsdrømme}

Museumschef Poul Sverrild, Historiens Hus, Hvidovre Kommune (DK)

Formålet med projektet var dels at udvikle en metode til identifikation af kulturarvsværdier i industrialismens og velfærdsstatens bebyggede strukturer dels at benytte kulturarv som strategisk element i den fremtidige kommuneudvikling. Projektet blev igangsat af Hvidovre Kommune i samarbejde med fonden Realdania og Kulturarvsstyrelsen, og alle 3 parter har bidraget til finansieringen. Selve udarbejdelsen af projektet er forestået af Hvidovre Kommune, Plan og Byg, Historiens Hus (Hvidovre museum) samt konsulentfirmaet Hausenberg, som har fungeret som sparringspartner og proceskonsulent.

Metoden i projektet har taget udgangspunkt i, at historien frem for genstanden er vigtig. Hvilke historier findes i området, og hvilke vil man arbejde videre med i fremtiden? Gennem denne afdækning har det været muligt at udpege konkrete materielle genstande eller immaterielle aktiviteter. Derudover har man med metoden ønsket at tænke bevaring og udvikling sammen til en helhed. Dette har krævet en analyse af de aktuelle samfundsmæssige problematikker, som det konkrete område står i samt en relatering af den udpegede kulturarv til de konkrete problemer. 
Kan kulturarven være en del af løsningen eller skal der arbejdes med at skabe en balance mellem modsatrettede udviklings- og bevaringsønsker? (Hvidovre Kommune 2008). Med udgangspunkt i ovenstående analyser skal der udarbejdes en vision for den fremtidige udvikling af området, og visionen skal omsættes til handling gennem konkretisering af projektidéer og planer. Konkret er man i Hvidovre Kommune nået så langt, at man har identificeret kulturarven i hele kommunen i form af et nyt kulturarvsatlas, der er indskrevet i den overordnede kommuneplan. Den videre omsætning af plan til virkelighed i form af vedtagelse af lokalplaner baseret på kulturel bæredygtighed samt konkretisering af kulturarvens muligheder som udviklingsfaktor er endnu ikke realiseret.

Projektets styrke har ligget i det faglige samarbejde mellem det lokale museum og kommunen. Det er også her, de væsentligste barrierer har ligget nemlig i de fagkulturelle forskelle. Endelige har det været en stor udfordring at skulle arbejde med kulturarv, der endnu ikke er erkendt som værdifuld i den bredere befolkning.

\subsubsection{Køge kystprojekt}

Direktør Jes Møller, Køge Kommune og museumsdirektør Christine Buhl Andersen (DK)

Kystprojektet handler om at lave en samlet plan/strategi for havne- og stationsområdet i Køge og bringe denne del af byen tættere på den centrale del af Køge by, der i dag er afskåret fra havneområdet og industriområder pga. jernbanen. Arealmæssigt udgør planområdet 24 ha, og kommunen har for at kunne realisere projektet opkøbt de fleste arealer og de eksisterende virksomheder fungerer på lejede arealer. Realdania er sammen med Køge Kommune partner i projektet. Som udgangspunkt for projektet er der foretaget registreringer af alle bygning og anlæg i området.

Projektets vision er, at kulturen i sin bredeste forstand skal drive byudviklingen, at detailhandlen og infrastrukturen skal styrkes og udvikles og at ny bebyggelse skal udformes kreativt og i høj kvalitet, at borgerne skal inddrages, og at bæredygtighed skal kendetegne alle aspekter af byudviklingen. Der er i 2009 udskrevet en konkurrence til prækvalificering af grupper, der ønsker at være med til at udarbejde planer for områdets udvikling.

Til understøttelse af arbejdet med udvikling af det nye byområde med kultur som drivkraft har kommunen i samarbejde med kunstmuseet i Køge, KøS Museum for kunst i det offentlige rum, udarbejdet et værdigrundlag for Køges byudvikling, „Kulturplan for Søndre Havn og Stationsområde i Køge - en strategi for byliv" som er blevet politisk vedtaget. Sideløbende med at der udvikles planer for området - benyttes området til forskellige kunst- og kulturprojekter. 


\title{
8.1.6 Limhamns kalkbrott - Här forvandlas historia till framtid
}

\author{
Kommunolog Mats Wirén, Malmö stad (SE)
}

Projektet har til formål at omdanne et tidligere kalkbrud til naturområde med adgang for offentligheden. Den kommercielle udnyttelse af kalkbruddet sluttede i 1996, og siden har naturen fået lov at overtaget bruddet. I perioden fra 1998 til 2007 blev der gjort forsøg på at få Malmø kommunalbestyrelse til at overtage området. I denne periode blev halvdelen af området udpeget som EU-habitat. I 2007-2008 indvilligede Malmø kommunalbestyrelse i at overtage området, og i dag arbejdes der med at gøre området tilgængeligt for offentligheden, udvikle områdets rekreative muligheder samt realisere området som reservat. Staten (Naturvårdsverket) og kommunen finansierer hovedparten af projektet, men områdets tidligere ejer (Heidelberg Cement) bidrager også økonomisk til projektet. Arbejdet med at realisere projektet er opdelt i 4 delprojekter. Der er foretaget en registrering af områdets biologiske, geologiske og oplevelsesmæssige værdier og flere tegnestuer er hyret til at komme med alternative forslag til områdets fremtidige benyttelse og beskyttelse. Disse forslag skal sammen med kommunens egne ideer samt rammerne for reservatudviklingen, som udvikles i samarbejde med Länstyrelsen, danne grundlag for et udviklingsforslag for området.

Projektets vigtigste erfaring er, at det kræver ihærdighed og vedholdenhed når der skal argumenteres for fastholdelse og udvikling af ledige arealer i byen (i dette tilfælde et tidligere industriområde) til ny værdifuld natur. Andre interessenter har ofte mange og meget tungt vejende argumenter for deres projektidéer.

\subsubsection{Groruddalen: Brobygning på tværs af etniske kulturer}

Kulturviter Synnøve Riise Bøgeberg, Oslo Kommune (NO)

Projektet startede i $2001 \mathrm{og}$ blev revideret/vitaliseret i 2007. Det er et større byfornyelsesprojekt der strækker sig over 10 år (2007-2016) og berører 130.000 indbyggere i 4 bydele i Oslo. Projektområdet er karakteriseret ved at have en stor koncentration af beboere af anden etnisk herkomst end norsk (40\%). Formålet med projektet er udvikling af en bæredygtig byfornyelse med vægt på forbedring af miljø- og levevilkår i området. Projektet er siden 2007 organiseret som et samarbejdsprojekt mellem stat og kommune. De overordnede strategier for området er: styrkelse af de blågrønne strukturer, styrkelse af den kollektive trafik, effektivisering af arealanvendelsen samt øget beskyttelse af kulturarv og større udbud af kulturaktiviteter. For hvert af de 4 byområder er der etableret arbejdsgrupper, der udarbejder årlige handleprogrammer. 
Grupperne er sammensat af repræsentanter for stat, kommune, direktorater, bydele og byrådsafdelinger.

Resultaterne af projektet kan bl.a. ses i form af synlige forbedringer i det fysiske miljø: flere mødepladser i byen der tager udgangspunkt i den eksisterende kulturarv, hver bydel har fået sin egen bydelspark, der giver mulighed for forskellige typer aktiviteter hvor folk bor, og der er kommet flere sammenhængende stisystemer for gående og cyklister.

Revitaliseringen af projektet i midten af 2000 betød, at projektet fik en social dimension, som det ikke tidligere havde haft. Det resulterede bl.a. i mere borgerinddragelse og større lokalt medansvar for implementering af planerne. Viden om beboernes behov har haft storindflydelse på projektets senere forløb bl.a. i etableringen af bydelsparkerne og mødepladserne. Projektet har bl.a. vist at der er stor forskel på, hvordan etniske nordmænd og indvandrere ser på og benytter naturen.

\subsubsection{Natur og kulturarv i regional udvikling og „community building".}

De 4 projekter beskrevet under denne overskrift har det til fælles, at regional udvikling er et centralt omdrejningspunkt, og at projekterne alene eller i meget høj er baseret på inddragelse af de lokale indbyggere. I alle projekterne indgår kommunerne som en vigtig samarbejdspartner og projekterne er "on going“.

\subsubsection{Herand - den kulturhistoriske bygda}

Una Eiken, Herand Landskabspark (NO)

Projektet startede for 12 år siden under mottoet „Herand ei god bygd å leva og bu i“. Der blev holdt flere borgermøder, hvor bygdens indbyggere prøvede at identificere, hvad der var godt og skidt ved lokalområdet. Møderne førte til konsensus om, at naturen og kulturminderne var en positiv resurse for lokalområdet, og at man ville arbejde videre med at prøve at skabe et fælles ejerskab til disse. Hermed var hovedstrategien for projektet skabt: at skabe sammenhold og kollektivt ansvar for det nære miljø og dets fremtid. Projektet kørte i starten som en del af bylauget, men fik i 2009 sin egen organisation Herand Landskapspark - et initiativ, der blev skabt i samarbejde med Fylkesmannen. Det konkrete arbejde har været organiseret i 4 arbejdsgrupper, som har stået for restaurering af kulturminder, afmærkning af stier samt opbygning af et informationscenter. En stor del af bygdens indbyggere (ca. 220) har været involveret i projektet, som er blevet støttet af Fylkesmannen og fylkeskommunen i Hordaland samt Jondal Kommune. Projektet har været finansieret gennem forskellige offentlige projektmidler - og er i fort- 
sat udvikling. Projektet er i en udfordrende fase idet man går fra en „anlægsfase" til en vedligeholdelse/drift fase.

\subsubsection{Bragdøya kystlag: Dugnad som sosial drivkraft og kulturbevarer}

Klaus Olesen, Bragdøya kystlag (NO)

År 1986 startede af 5 privatpersoner, der stiftede Bragdøya kystlag med det formål at opbygge og drive et kystkulturcenter i et nedlagt makrelsalteri. Det var hensigten at skabe et sted, hvor lokalbefolkningen kunne lære basale kundskaber om livet langs kysten gennem deltagelse og praktisk aktivitet. Kulturcenteret rummer i dag båd værksted og andre aktiviteter og der formidles bl.a. kundskab om både og bådrestaurering. Kystlaget driver derudover bådruter med daglig afgang, cafeteria og catering. Det var visionen i starten, at andre frivillige organisationer skulle inddrages i arbejde. Dette lykkedes ikke helt og i dag drives aktiviteterne af kystlaget alene i et tæt samarbejde med kommunen. Kystlaget har ca. 650 medlemmer, en omsætning på 3,2 mio. NOK, 3 fastansatte og en stor mængde frivillig arbejdskraft. Foreningen er en selvstændig forening med egne vedtægter og bestyrelse, og årsmødet er den øverste myndighed. For at være medlem af Kystlaget betales et årskontingent på 350 NOK. Det frivillige arbejde er organiseret i en række arbejdsgrupper med klart afgrænsede arbejdsområder f.eks.: køkkendrift, småbådsvedligeholdelse, fåregræsningslaug, bådbygning og friluftsliv. Foreningens økonomi er i dag baseret på dels egen indtjening (1,6 mio. kr.) dels på stats-, kommunal- og amtslig støtte (henholdsvis på 1 mio. NOK øremærket til bådrestaureringsaktiviteter og 2 gange 280.000 NOK). Kystlagets aktiviteter er i dag forudsætning for, at en række børneinstitutioner og skoler dagligt benytter øen, samt at en række tilbagevendende begivenheder kan finde sted på øen, herunder særlige gudstjenester og festivals. Foreningens største problem i dag er, at en stor del af den frivillige arbejdskraft er ved at komme godt op i årene, og at energien til det frivillige arbejder bliver mindre. Foreningen overvejer, hvordan man kan skære ned på aktiviteterne og evt. kommercialisere cateringafdelingen. Det har været en vigtig forudsætning for kystlaget succes, at der tilbage i 1980erne, hvor foreningens egen økonomi var dårlig, var økonomisk opbakning fra kommunen (med støtte fra statslige midler) til etablering, renovering og drift af centerets bygninger og projekter, og at det har været muligt at holde kom-mercielle interesser ude. Det har ligeledes været en forudsætning, at der har været en stærk og visionær person til at holde projektet på rette kursus. Projektets svaghed er, at man ikke har været god til at rekruttere børn, unge og voksne med anden etnisk herkomst. Projektet er sårbar i forhold til udskiftning af centrale 
personer i bestyrelsen, ligesom det er vanskeligt at lave langtidsplanlægning for arbejde, der primært baserer sig på frivillighed.

\subsubsection{Multifunktionelle landskaber - strategier, værktøjer og projekter}

Udviklingskonsulent Anders Rask Storgaard, Skive Kommune (DK)

Formålet med projektet var at afprøve nye former for planlægning for det åbne land med udgangspunkt i lokalområder og deres indbyggere. 5 lokalområder deltog i projektet og 5 studiekredse bestående af både landmænd og landsbybeboerne med andre erhverv arbejdede gennem $11 / 2$ år på at udarbejde en strategi/vision samt en konkret plan for udvikling af deres lokalområder. Oplægget til studiekredsenes arbejde var, at de i deres udvikling af strategi og vision skulle tage udgangspunkt i deres lokale landskab, dets kvaliteter og problemer. Studiekredsenes arbejder blev faciliteret gennem workshops, ekskursioner, individuel vejledning og møde med et eksternt ekspertpanel. Efter studiekredsenes færdiggørelse af strategi og plan blev dele af planerne indarbejdet i kommuneplanen, således at de formelle rammer for virkeliggørelsen af planerne er på plads. Studiekredsene arbejder nu videre med støtte fra Skive Kommune på realisering af planerne. Til understøttelse af dette arbejde er der i de fleste lokalområder nedsat nye eller supplerende arbejdsgrupper. Det er en vigtig motivationsfaktor for den videre proces og for bevarelsen af den tillid, der er skabt mellem de lokale aktører og den kommunale forvaltning, at sikre muligheder for at planer bliver helt eller delvist realiseret. Projektets vigtigste erfaring er, at det har været muligt at mobilisere lokalsamfundene til at deltage aktivt og ansvarligt $\mathrm{i}$ en planproces til stor nytte for både kommuneplanarbejdet, men også som et vigtigt bidrag til udvikling og fastholdelse af lokalsamfundet.

\subsubsection{Miljø venlig bygd}

Borgmester Albert Ellefsen, Vága Kommuna (FO)

„Miljø venlig bygd“ er et initiativ der er igangsat af Færøernes Turistråd i 1996 for at skabe et renere og mere pænt fysisk miljø i både by og bygd. Som samarbejdspartner i projekter indgår Miljøstyrelsen og interesseorganisationen FNU (Miljø og Natur interesseorganisation). Fra 1/1 2010 ledes projektet fra kommunens tekniske forvaltning afdeling for Miljø og Natur. Projektet er finansieret af kommunen og har en årlig bevilling på 0,5-1 mio. DKK. Projektet holdes i gang af en kommunal ildsjæl sammen med en borgergruppe. Der har været arbejdet med mange forskellige te-maer i årenes løb lige fra ren by, og vandafledning til husdyrhold, turisme og kulturarv. Man arbejder med at realisere et 
grønt friareal i byens centrum, og man har fået udarbejdet en handleplan til understøttelse af arbejdet på længere sigt. Årligt afholdes en miljødag og alle bygdens borgere opfordres til at påtage sig et ansvar for at holde byen og dens omgivelser i pæn stand. Kommunen er 3 gange blevet valgt til den miljøvenligste bygd på Færøerne. Det er lokalsamfundets overbevisning at initiativet har medvirket til at give byen omtalen som en af de smukkeste byer på Færøerne - en positiv omtale, der medvirker til at tiltrække turister til området.

\subsubsection{Natur og kulturarv i kommunale udviklingsstrategier}

Fælles for projekterne under denne overskrift er, at natur og kulturarv er brugt som centrale elementer i strategier for kommunal udvikling. Eksterne drivkrafter har spillet en betydelig rolle i 3 af projekterne, hvorimod det 4. projekt har opstartet en ny planproces med udgangspunkt i en tværfaglig projektgruppe bestående af både traditionelle planmedarbejdere og sundhedsrelateret medarbejdere.

\subsubsection{LONA}

Stadsarkitekt Gertrud Richter, Örkelljunga kommune og Ingegerd Ward, Naturvårdsverket (SE)

I Örkelljunga Kommune i Skåne har man med udgangspunkt i det Nationale Naturbeskyttelsesprogram (LONA) igangsat en naturbeskyttelsesplanlægning for hele landbrugslandskabet i kommunen. Initiativet blev sat i gang efter en henvendelse fra Lantbrukarnas Riksförbunds (LRF en upolitisk interesseorganisation for personer med interesser i jordbruget, naturen og landdistrikter). Lokalgruppen i kommunen mente, at der var behov for initiativer, der kunne være med til at løfte landdistrikterne og landsbyerne og ikke mindst aktivere landbrugere, som der bliver færre og færre af i kommunen. Projektet har dels bestået i at kortlægge og analysere kommunens kultur- og naturværdier dels i formidling af disse værdier i landsbyrapporter (kommunale delområder). Et vigtigt element i formidlingen har været at vise den tætte sammenhæng mellem natur- og kulturmiljøerne og menneskernes brug af og virke i disse. Arbejdet har været guidet af en arbejdsgruppe bestående af både embedsmænd, politikere, lokalrådsformænd og interesseorganisationer. Resultatet af arbejdet er et naturbeskyttelsesprogram for hele kommunen, der har inspireret til en overordnet vision for kommunen. Visionen indeholder en „rygrad“ (infrastruktur og service), hvor landbyudviklingen kan og skal ske og en „upplevelsestråk“, som har sine potentialer i det åbne land og dets aktiviteter. Det springende punkt i projektet er nu implementeringen, og her synes der at være en vis træghed. Hvilke vir- 
kemidler skal der satses på? Man håber på, at Leader + kan bruges i denne sammenhæng

Selve udarbejdelsen af naturbeskyttelsesstrategien er finansieret af både kommunen og den statslige instans „Naturvårdsverket". Staten har medfinansieret projektet gennem naturvårdprogrammet LONA, som har til formål at støtte kommunale/lokale naturbeskyttelsesinitiativer, der kan medvirke til øge mulighederne for især det landbynære friluftsliv, forbedre sundheden samt bidrage til at skabe lokal vækst. Programmet har forløbet siden 2004. Projektet har bidraget til at øge opmærksomheden på det lokale naturbeskyttelsesarbejde i kommunerne - selv i kommuner som tidligere har været meget lidt engageret i dette arbejde ligesom det er lykkes at øge den politiske støtte til naturbeskyttelsesarbejdet. Kund-skabsniveauet om naturen og dens tilstand er øget gennem de mange investeringer og naturbeskyttelsesplaner, der er blevet udarbejdet - bl.a. med hjælp fra interesseorganisationer og frivillige. Endelig er det gennem de mange igangsatte projekter lykkedes at give den sociale dimension en øget betydning i naturbeskyttelsen.

\subsubsection{Dejlig er fjorden}

Marie Garsdal Brøsted, Mariagerfjord Kommune (DK)

Med fonden Realdania og Kulturarvsstyrelsen som medinitiativtagere igangsatte man i Mariagerfjord Kommune i 2008 et arbejde med at kortlægge kommunens kulturhistorie og kulturværdier for herigennem at sætte fokus på kulturarven og nyttiggøre den i den forestående kommuneplanproces. Det var intentionen med processen, at projektet kunne medvirke til at øge sammenhængskraften i den nye Mariger Kommune, som er sammensat af 6 tidligere kommuner lokaliseret omkring Mariager Fjord, og at den kunne være med til at åbne politikkernes øjne for kulturarven som en resurse, der skal forvaltes ansvarligt og visionært. Projektet blev ledet af kommunen i tæt samarbejde med kommunens museer. Derudover var der et par konsulentfirmaer tilknyttet projektet. En styregruppe bestående af centrale embedsmænd og politikere har været med til at sikre den politiske forankring og indarbejdelse af kulturarvsdimensionerne i kommuneplanen. Projektet har bestået af to dele: den første har handlet om registrering af fjordlandskabets kulturhistorie, som er afrapporteret $\mathrm{i}$ udgivelse af et fjordatlas, og om at få resultaterne af denne registrering ind i kommuneplanen. Den anden del af projektet handler om det fremadrettede arbejde: at få udarbejdet en strategi for forvaltning af det afdækkede kulturhistoriske potentiale. Dette arbejde er endnu ikke igangsat. De store udfordringer i forløbet har været den korte tidsramme, den politiske forankring af projektet og timingen i forhold til kommuneplanprocessen. Der har været stor interesse for projektet blandt befolkningen og den politiske forankring er godt i gang. 


\subsubsection{Lavaelvebyen Garðabær}

Planeringschef Arinbjorn Vilhjamsson (IS)

Dette projekt handler om at udarbejde en effektiv beskyttelse og forvaltning af naturfænomener i bynære omgivelser. Garðabær er en forstadskommune til Reykjavik og har 10.000 indbyggere. Naturforholdene, der ønskes beskyttet i projektet, er et stort lavaområde der går helt ind til byen. Området har siden 1985 haft status som beskyttelsesområde i kommuneplanen, en staus der dog ikke er blevet taget alvorlig. I midten af 2000 blev der bl.a. bygget et stort Ikea på lavaområdet, hvilket udløste store protester fra borgerne i kommunen. Dette har nu fået kommunen i samarbejde med Den islandske miljøstyrelse til at udarbejde en ny beskyttelses- og forvaltningsplan for området, og det er intentionen, at hele området skal have status som naturbeskyttelses og fritidsområde. Området får status som kommunelt og statsligt naturværnsområde. Processen har bidraget til en positiv diskussion af lavaens betydning for lokalsam-fundet og at naturplanlægningen tages seriøst i fremtiden. Den største udfordring i processen har været at få løst konflikter med private lodsejere, der har haft planer om f.eks. at bygge en golfbane på lavaområdet.

\subsubsection{Kortlægning af forskolers og skolers anvendelse af grønne områder}

Folkhälsoplanerare Nina Granath, Nacka Kommun (SE)

Projektet formål har været at kortlægge børns brug af grønne områder (inklusiv strand og vandområder) i kommunen og bruge denne kortlægning som udgangspunkt for udarbejdelsen af kommunens nye oversigtsplan der skal være færdig i 2010, hvor folkesundhedsperspektivet er udpeget til at være et centralt tema. Projektet er blevet igangsat af en projektgruppe, der havde til opdrag at lave en grøn strukturplan for Nacka. Projektgruppen var meget tværfagligt sammensat med deltagelse af både traditionelle plan- og miljømedarbejdere og sundhedspersonale. Desuden har den lokale naturbeskyttelsesforeningen indgået som en samarbejdspartner. De har bl.a. hjulpet med at få kontakt til skolerne og få dem til at deltage i projektet. Motivationen for at opstarte projektet har bl.a. været, at en $1 / 4$ af kommunens indbyggere er børn og et ønske om at imødekomme børnekonventionens bestemmelser om, at børn har krav på et sikkert og trygt miljø, og at de har krav på at blive hørt og inddraget. Da planarbejdet endnu ikke er tilendebragt er der ingen erfaringer med det nye plangrundlag, men erfaringer fra processen viser, at der er skabt helt ny viden om børns brug af de grønne områder. Erfaringerne viser også, at processen har været mere resursekrævende end antaget fra starten, og at det har været svært at få skolerne til at deltage i projektet, selv om de udtrykker sympati for det. 


\subsection{Natur, kulturarv och näringsutveckling}

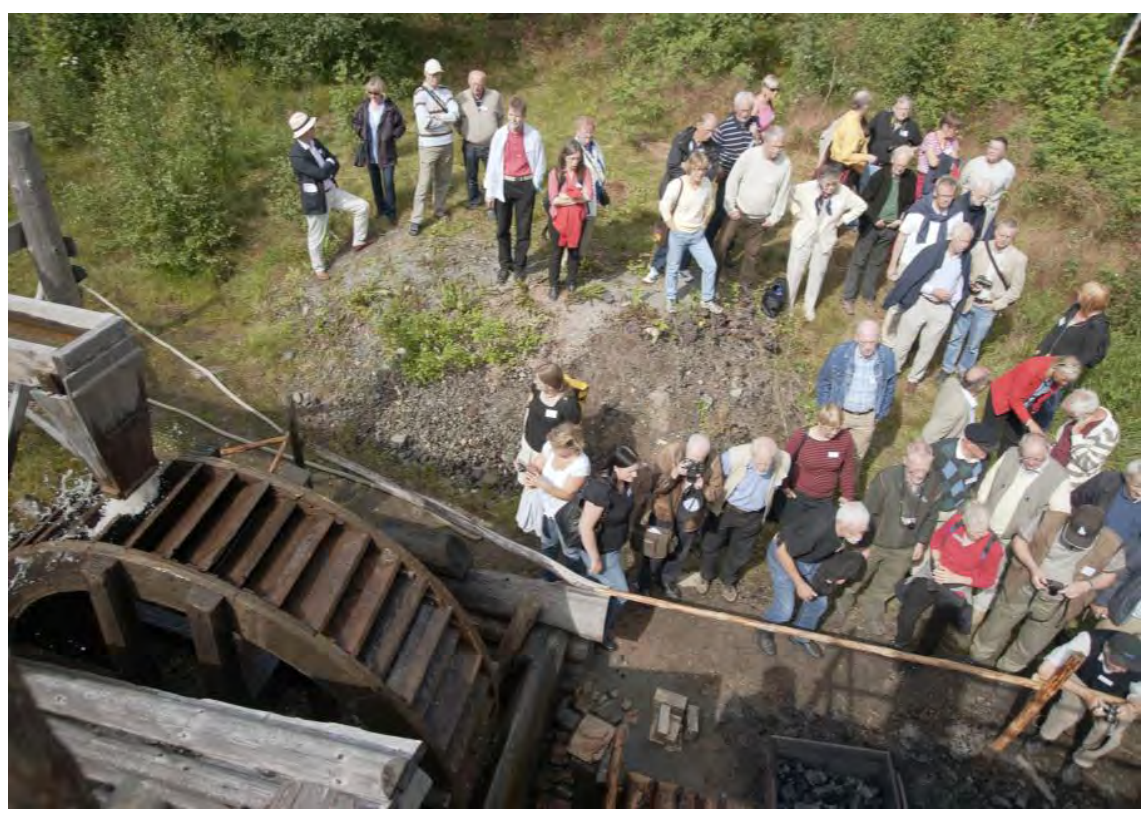

Landskapet som resurs för hållbar tillväxt. Nordisk konferens. Finland, den $10-11$ februari 2010

\subsubsection{Broad values creation based on nature and cultural heritage - Contributions to a sustainable glocal development}

Per Ingvar Haukeland, PhD, Telemark Research Institute, Norway

The presentation will outline the research conducted in the evaluation of two national programs in Norway: Verdiskapingsprogrammet for kulturminner (The values creation program for cultural heritage 20072010) coordinated by the Directorate for cultural heritage, and Naturarven som verdiskaper (Natural heritage as values creator (20092013) coordinated by the Directorate for Nature Management. The main aim of these programs is to develop nature and cultural heritage into resources for local and regional community economic development. Furthermore, it shall take care of nature and cultural heritage through sustainable use, and it shall develop and spread knowledge about the experiences in doing so in the 22 main projects.

Underlying both programs are White Papers stating the importance of a broad focus on values creation. For example, in the White Paper "Living with cultural heritage" (St.meld nr 16, 2004-2005), it says: "Cultural heritage and cultural environments are in a lesser extent being used as resources in community development. They can be the basis for cultural, social, economic and environmental development and values 
creation in local communities and economies." This presents the projects with a series of challenges: identification and consciousness-raising around nature and cultural heritage as resources for broad values creation that includes environmental, cultural, social and economic forms of values creation; how to combine use and protection in a sustainable way; local mobilization and engagement across sectors locally, regionally and nationally; conflict management between use and protection; developing and combining both private goods and collective goods. The term "values creation" comes from economics, but in these programs, it is extended. As economic values creation shows values created between income and expenditures, cultural values creation shows how cultural values (such as identity, pride, local knowledge...) are strengthened or weakened as a result of the investments in the projects. Similarly, the aim is to enhance social values creation (sense of community, collaboration, networks...), and environmental values creation (biological diversity, less pollution, climate friendly, energy efficiency...).

Our (action) research connected to sustainable local and regional development and to the evaluation of these programs, show that economic development is not enough to promote sustainability in development, there is a need for environmental, cultural and social development. We see this also part of a holistic perspective on sustainable development that we have also put into a glocal context. What is done locally, needs to have a global perspective, and global efforts need to be rooted in local and endogenous processes. Furthermore, we find that there is not only innovations and entrepreneurial activities involved across spheres and sectors that are necessary for sustainable development, we also find that the environmental, cultural and social values creation are investments in the resource base for economic values creation; in other words, the different forms of values creation build on each other. We find this to be an example where there is a creative interplay between the production of private goods and collective goods. We also find that there are differences in priorities when it comes to the different forms of values creation dependent on which phase the project is in, which needs also to be included when one makes support schemas for such projects and when evaluating them. There are many challenges ahead in order to enhance broad values creation based on nature and cultural heritage in a glocal sustainability perspective, among them the need to see nature and culture more together, work more across sectors, coordinate support schemas, balance between private and collective goods, institutionalization. 


\subsubsection{Att sälja eller marknadsföra kultur- och naturmiljö. Perspektiv på planering och platsmarknadsföring}

Krister Olsson, Urbana och regionala studier, Kungliga Tekniska Högskolan, Stockholm, Sverige

Samhällets utveckling från ett industrisamhälle till ett postindustriellt kunskapssamhälle har inneburit nya förutsättningar för lokal och regional utvecklingsplanering. Allt tydligare framträder ett konkurrensspel mellan städer och regioner som handlar om att framstå som attraktiv för människor, företag och investeringar. Utvecklingsarbetet inriktas på många platser i huvudsak mot att försöka åstadkomma en konsumtion i vid mening i den egna staden eller regionen. Det handlar om turism och besöksnäring, festivaler av olika slag, anläggningar för kultur och sport, detaljhandel och underhållning och byggnadsprojekt som ska visa på framåtanda, dynamik och attraktivitet. Planering med denna inriktning kan förstås och diskuteras i termer av platsmarknadsföring.

I dessa sammanhang ställs stora förväntningar på kultur- och naturmiljö och andra livsmiljökvaliteter som resurser för lokal och regional ekonomisk utveckling. Traditionellt har kultur- och naturvården i huvudsak varit en expertfråga och ett offentligt ansvar som inriktats mot avgränsade områden och kvaliteter med högt vetenskapligt värde. I grunden kan detta beskrivas som ett produktorienterat förhållningssätt med syfte att identifiera kvaliteter och miljöer för långsiktigt bevarande. Denna syn på kultur- och naturvårdens roll i samhällsplaneringen dominerar alltjämt, såväl inom sektorsverksamheterna som hos andra parter. Med denna ut-gångspunkt tolkas platsmarknadsföring ofta som en fråga om att förmedla eller "sälja" en definierad produkt, d.v.s. i detta fall utpekade kvaliteter och avgränsade miljöer. Kultur- och naturmiljö som resurs för utveckling och som produkt framträder som något förutbestämt eller givet.

I ett marknadsföringsteoretiskt perspektiv är det emellertid olika gruppers efterfrågan och behov som definierar produkten och på så sätt avgör vad som är en resurs för utveckling. Platser är i sig själva komplexa och mångfasetterade med många olika betydelser för olika grupper och intressenter. Olika grupper eller delmarknader uppfattar samma plats på olika sätt och definierar på så sätt platsen som produkt på olika sätt. Vad som egentligen är en resurs för utveckling och hur platsprodukten ska avgränsas och beskrivas är med andra ord inte givet, utan måste vara föremål för empirisk undersökning. Platsmarknadsföring kan mot denna bakgrund beskrivas som en efterfrågeorienterad process, där platsen betraktas som en uppsättning produkter, skapade av platsens befintliga och potentiella kvaliteter enligt olika gruppers behov och önskemål. Om kultur- och naturmiljö ska fungera som resurs i lokalt och regionalt utvecklingsarbete krävs nya synsätt och arbetssätt, där ut- 
gångspunkten är efterfrågan och behov hos olika målgrupper snarare än sektorsverksamheternas traditionella expertkunskap.

\subsubsection{Branding and cultural heritage}

Armgard Weine, senior principal, Ministry of Culture, Faroe Islands

In a globalised world national image and reputation are more important than ever. The world is one market, and countries, cities and regions compete with one another to attract capital, companies and tourists and to export products and services.

In order to manage the national image and reputation, the Faroese government has launched a project on its Competetive Identity, that is a model for enhanced national competetiveness in a global world and a synthesis of brand management with public diplomacy and with trade, investment, tourism and export promotion. The theory of competetive Identity is based on six channels in a hexagon: Tourism, brands, policy, people, investment and culture.

The Competetive Identity process concludes that storytelling, tradition, culture and roots are some of the key components of the Faroese identity and that there is a low general awareness of the Faroe Islands that needs to be addressed. The key facts to image building include natural and cultural heritage. Eco-tourism is seen as a main driver for business development.

In this Competetive Identity-approach cultural heritage is used as a tool for development of society and buisness. The cultural heritage holds a strong position in the Faroe Islands. It is, among other things, reflected in music, dance and crafts and creative industries are using cultural heritage actively in their brand identity.

Cultural heritage as a tool for branding can be problematic though: The killing of pilot whales is a deeply rooted part of Faroese tradition and is of economic, social and cultural significance, but it may also mean loss of export value and a bad reputation abroad.

- The old whaling station við Áir is a unique industrial plant from the 20th century, but until now national funding has not been found for the conservation of the whaling station. But maybe the conservation of the whaling station should be seen, not from a national, but from a global viewpoint. And from a Competetive Identity point of view it would be wise to place a Marine Institute in connection with a maritime museum at the site in order to offset bad publicity

So with the Competetive Identity for the Faroe Islands laid out: Will the Faroese branding process influence decision making on cultural heritage so that it is economical and reputational considerations instead of con- 
servational considerations underlying the decisions on managing cultural heritage?

\subsubsection{Sveriges handlingsplan för kulturella och kreativa näringar}

Per-Olof Remmare, Tillväxtverket, Sverige

Regeringen beslutade 2009 om en handlingsplan för kulturella och kreativa näringar. Handlingsplanen bygger på intentionerna i regeringens övergripande styrdokument för den regionala tillväxtpolitiken Nationell strategi för entreprenörskap, sysselsättning och regional konkurrenskraft 2007-2013. Syftet med handlingsplanen är att skapa goda förutsättningar entreprenörer samt potentiella och blivande företagare inom kulturella och kreativa näringar att utveckla sina affärsidéer och företagande.

I handlingsplanen formuleras nio olika deluppdrag till nationella myndigheter och organisationer. Tillväxtverket, Tillväxtanalys och VINNOVA (Verket för innovationssystem) är satta att koordinera deluppdragen i samverkan med olika myndigheter inom kultursfären, som t.ex. Statens Kulturråd, Riksantikvarieämbetet, Riksarkivet, Svenska Filminstitutet och Konstnärsnämnden.

De nio deluppdragen handlar om:

- Rådgivning till företag

- Programsatsning på inkubatorer för kulturella och kreativa näringar

- Mellanhänder/nätverk/modeller för samverkan

- Entreprenörskap i kulturella och kreativa utbildningar

- Innovation och design

- Ledarskap och arbetsorganisation

- Studie om finansieringsbehov

- Förbättrad statistik

- Behov av kompetensutvecklingsinsatser

Tillväxtverket är ansvarig myndighet för att koordinera 4 av deluppdragen (Rådgivning till företag, Mellanhänder/nätverk/modeller för samverkan, Entreprenörskap i kulturella och kreativa utbildningar och Behov av kompetensutvecklingsinsatser). Deluppdraget Innovation och design har Tillväxtverket i uppdrag att koordinera tillsammans med VINNOVA.

Intresset för Handlingsplanen för de kulturella och kreativa näringarna ute i landet mycket stort. Inom Tillväxtverket kommer det att tas fram ett nationellt program för Kulturella och kreativa näringar. Inom ramen för arbetet med handlingsplanen i sin helhet kommer det att under 2010 genomföras regionala dialogrundor. 
Tillväxtverket ser också kopplingar och synergier med andra nationella program som verket ansvarar för. Bland dessa kan nämnas Turismprogrammet, Kvinnors företagande, Program för företagare med utländsk bakgrund, med flera. Tillväxtverket ser även kopplingen till EU:s fonder och program som prioriterad, liksom liknande projekt eller uppdrag i de nordiska länderna för att bidra till ett ökat kunskaps- och erfarenhetsutbyte mellan länderna. Det NMR-finansierade Krea Nordprojektet kan nämnas som ett exempel.

I arbetet med handlingsplanen är natur och friluftsliv inte av regeringen särskilt utpekade områden, men Tillväxtverket ser ändå en samverkan med dessa sektorsintressen som värdefull - inte minst för att kunna lyfta fram den turistiska dimensionen i arbetet med handlingsplanens olika deluppdrag.

\subsubsection{Economusée - showcasing artisan craft producers at work, allowing our cultural heritage to earn its keep}

Terje Inderhaug, project leader of Economusée Northern Europe, Hordaland County Council, Norway

Economusée Northern Europe is a European project between 7 North European countries funded by the NPP-Northern Periphery program. It is also an innovative cooperation based on a successful concept and network with more than 50 artisan member companies that has been established in Eastern Canada during the last 25 years. There are today more than 350 artisans in Canada who proudly presents and promotes their crafts and economusees, - to more than 750,000 visitors a year. All the economusees are private companies that fund their daily operations by themselves.

An Economusee combines culture, craft and tourism to create an economy platform for craft artisans practicing traditional techniques in order to help the crafts survive and create new jobs. The European project, which focuses on rural or remote communities, will assist with the transformation of 18 artisan businesses into Economusees that will showcase their indigenous crafts and traditions, as well as providing new jobs and training of young people.

\section{An economusee is a heritage that earns its keep by combining economy and culture!}

An artisan craft business that would like to become an economusee will have to go through a comprehensive process of selection, feasibility study, contracting and physical transformation. There are six principal components that are universal for the economusee which needs to needs to be an integral part of the transformation, i.e. 1. the reception and welcoming area, 2. the production and creation room, 3. traditional \& historic produc- 
tion area, 4. contemporary crafts presentation, 5 . information \& documentation centre and 6. the important boutique or sales and display area.

A transformation process requires the intervention and cooperation between the artisan and a team of specially trained ethnologists, architects, designers, as well as various building trades. However, there are adaptations to the concept in the Nordic countries because of different socio-economic contexts, types of handicrafts and places etc., where these trades are practiced. Being an economusee also provide membership of a non-profit ideal organization that have committees, codes of ethics, and business advisors etc., to support their quest for excellence.

\section{Spin-offs and sustainability}

There are several important spin-offs from an economusee that needs to be mentioned:

- Promoting the status of the artisan

- Transmitting creative skills to the public as well as to the next generation

- Conserving intangible heritage by producing tangible products

- Promoting the diversity of cultures, trades and know-how

- Bringing the artisan and consumer into close contact \& increasing tourism attractions

An Economusee therefore creates conditions for artisans to continue to produce their crafts and become sustainable by increase in sales and by showcasing their heritage to the local community and tourists. Consequently, an Economusee often become important heritage "institutions" for the local communities as they often portray a craft that is an important shared heritage for many people in an area.

\subsubsection{Læsø Salt - a 1000 year old local craft turning into a modern survival and branding strategy for an island}

Torsten B. Jakobsen, CEO the Læsø Foundation, Læsø Salt A/S and Læsø Kur Aps, Denmark

Læsø is a small Danish island with 2000 inhabitants. Læsø is placed in Kattegat $1 \frac{1}{2}$ hours travel by ferry from mainland Denmark. The main sources of employment have been fishing and farming, but the last decades have seen a drop in the primary sector - and tourism is now the biggest employer in summer. In winter unemployment is dominant.

\section{Tradition and innovation}

In 1991 a historian, an archeologist and a "crazy" local teacher started the project Læsø Salt. Rediscovering the islands traditional craft of mak- 
ing salt, they combined excavations of the local natural and cultural heritage with the education and activation of local youths.

Salt works were plenty on Læsø in the Middle Ages. The salt industy boomed around 1300-1400 AD but faded after that and came to a halt around $1700 \mathrm{AD}$ due to lack of wood for the furnaces and falling world market prices on salt. The salt project erected a reconstruction of an old salt work with production and storytelling based on the old craft. Thus creating a tourist attraction as well as a food production for sale.

\section{Spreading the news}

In 2004 the project had turned into a profitable business with around 75,000 annual visitors and distribution af salt to 300 shops in mainland Denmark. The Læsø Foundation was established with the aim of generating new activities on Læsø based on salt.

In 2007 Spegeriet openede, offering a range of food produced and prepared with Læsø Salt. Today the danisk consumer can buy high end products containing Læsø Salt such as ham, sausages, cheeses, butter, potato chips, biscuits and sweets. Next up are bread, smoked salmon and shrimps.

In 2008 Læsø Kur, a high end Spa opened its doors, offering skin treatment and wellness using Læsø Salt. A range of skin treatment products soon followed.

\section{The Salt Island}

Talking with Danes today - young or old - you can be sure that they will connect Læsø with salt - and the word salt with Læsø. In most Danish stores selling quality food you will see the little white bag with Læsø Salt and lately they are beginning to show in southern Norway and western Sweden as well. Often people visit Læsø and buy salt as a souvenir - but just as often they are given Læsø Salt as a gift and then decide to go to the island out of couriosity.

As in most parts of the world Læsø has been in a recession for the last 18 months. Læsø Salt is operating in the fields of luxury foods, tourism and wellness, all of which has seen drops of $30-40 \%$ in earnings lately. But approaching our 20th birthday, we still feel young and vibrant with the confidence of a 1000 year old.

\subsubsection{Farming for health}

Anna Kirveennummi, Katriina Soini, MTT, Agrifood Research Finland

Green Care refers to the utilisation of the rural environment and especially the abundant resources of farms, including the animals, plants, gardens, landscapes, social environment and everyday routines, for producing various kinds of social, health and education services. The activi- 
ties may vary from intensive riding or horticultural therapy to working on the farm or simply enjoying the rural environment.

The core idea of Green Care is not new, because the therapeutic properties of nature have been known for a long time. People have used to turn closer to the nature when they have wished to detach themselves from work and the urban environment or when they have needed rehabilitation after social or health problems. Farms have offered work and shelter for people suffering from different types of exclusion. Many institutes in the social sector, such as prisons and homes for the elderly or children, have been connected to farms and farm work has been part of the everyday life of their residents. What is new in Green Care is that the positive impact of the farm and rural environment on well-being of the humans is better acknowledged and it is seen as a resource in providing social and health services the demand of which is increasing.

Green Care can be considered as a social innovation, since it offers a new perspective to arranging social and health services. In many cases, the activities have emerged from "bottom-up", from the initiatives of entrepreneurs and customers. The phenomenon is growing stronger simultaneously in several European countries, where agriculture is faced with rapid structural changes and new solutions are searched for in the social and health sectors. For farms Green Care gives an opportunity to take advantage of the farm environment and know-how in a completely new way. For rural residents Green Care means social and health services, as well as new employment opportunities in the neighbourhood region. The impacts on the viability of the rural areas will be multiplied as the social and health care enterprises use the local and regional services. From the perspective of the society Green Care increases the range of services available in the social and health sectors and the opportunities to select the best type of care for each specific case.

\section{Green Care in Finland}

The first Finnish study on Green Care farms was conducted in cooperation between the MTT and Finland Futures Research Centre. The presentation is focused on the uses of nature and cultural values in Green Care activities and rural entrepreneurship.

\subsubsection{Valdres nature and culture park - heritage as common interest in rural development}

Kjell Arne Berntsen, ledare för regionrådet för Valdres och Katharina Sparstad

Valdres Natur- og Kulturpark instiftades 2007 som en vidareutveckling av Regionrådet för de 6 kommunerna i Valdres och som ett nationellt pilotprojekt för regional utveckling. En långsiktig varumärkesuppbyggnad kopplat till områdets natur- och kulturskatter ska ge större värdeskap- 
ande och livskraft i kommunerna. Valdres Natur- og Kulturpark använder de franska regionalparkerna som strukturmodell. Valdres blev en spjutspets i Värdeskapandeprogrammet 2006. Största anledningen till detta var att Valdres har 6 av landets 28 stavkyrkor. Dessutom är Valdres den region i Nordeuropa som har flest levande fäbodar. Programmet inkluderar många aktörer såsom Miljöskyddsdepartement, Oppland fylkes 6 kommuner, Riksantikvarien, Kulturrådet, Fylkesmannens landbruksavdelning, lantbruksorganisationer (stølslag), historielag, forskningsmiljöer, olika bidragsinstanser som t.ex. Innovasjon Norge.

Lantbruk utgör stommen i Valdres Natur- og Kulturpark. Samtidigt är gårdarna väldigt små och har generellt dålig ekonomi. Detta för med sig nedläggningar av lantbruk och upphört bruk av fäbodar. Valdres försöker stoppa denna utveckling genom att stärka böndernas ekonomi. Samtidigt arbetas det med en modell för ett målinriktat förvaltande av fäbodvallarna. En del fäbodvallar hotas också av exploatering. Problemställningar kopplade till bruk kontra skydd är speciellt aktuellt för fäbodvallarna med tillhörande områden.

Det huvudsakliga fokuset har varit att bidra med tilläggsnäringar i form av upplevelseturism och lokal förädling. Det har etablerats ett nätverk där det arbetas med produktionsutveckling.av gårdar och fäbodar. Ett regionalt samarbete om stavkyrkorna är upprättat och därutöver ingår 30 byggnadsverk i ett restaureringsprojekt. Valdres har anställt en byggnadsrådgivare som samarbetar med de lokala museerna. Dessutom har Valdres utarbetat en vägledning för byggnadsskick vid uppförandet av nya byggnader.

Det är viktigt att förbättra kunskapen och känslan av lokalt ägandeskap till kulturminnena genom informationsinsatser. Kulturminnen måste göras tillgängliga på Internet, i publikationer och ute i landskapet. Därför har Valdres Natur- og kulturpark utarbetat en vägledning för skyltning.

I takt med ökat intresse för restaurering, traditionella hantverk och lokala mattraditioner, är det viktigt att Valdres bidrar till en kompetenshöjning. Valdres arrangerar därför många olika kurser - i samarbete med andra aktörer i och utanför Valdres.

\subsubsection{Kulturarvet som resurs för näringsutveckling sett ur dansk synvinkel}

Michael Lauenborg, Kulturarvsstyrelsen, Danmark

Danmark er sammenlignet med de øvrige nordiske lande et relativt lille land, hvor man umiddelbar skulle forstille sig en forholdsvis jævn og ligelig økonomisk udvikling. Sådan forholder det sig kke. Danmark har to store vækstområder: Et centreret omkring hovedstadsområdet, der i dag stort set dækker det meste af øen Sjælland og et andet centreret om- 
kring den østjyske motorvej på strækningen fra Kolding til Randers. Området er blevet kaldt DØM (Den Østjyske Millionby) idet det byerne Kolding, Vejle, Horsens, Århus og Randers i større eller mindre grad er vokset sammen omkring E45. Motorvejsnettet og udviklingen har betydet, at mere end $25 \%$ af virksomhederne i Danmark nu er placeret indenfor en afstand på 2 kilometer fra en motorvej.

Områderne langs den jyske vestkyst og syd for Fyn og Sjælland, er blandt taberne i denne sammenhæng. De bysamfund der ligger i tilknytning til disse landdistrikter har ligeledes store vanskeligheder; mange industrier er lukket og offentlige arbejdspladser er nedlagt (sygehuse, seminarer, rådhuse, kaserner). Landbruget er langt hen ad vejen blevet en industri der ikke kræver mange hænder. Gårdene bliver sammenlagt til større brug og resultatet er blevet, at mange landsbyer har tomme huse og gårde. De fleste håndværkere er forsvundet fra landsbyerne og det samme gælder dagligvareforretningerne. Og der er ikke kommet erstatningserhverv.

Disse områder har rigtig store udfordringer i relation til at skabe et nyt liv, på baggrund af lokalt forankrede tiltag der kan skabe en sund og naturlig baseret økonomi. To eksempler på områder der er i denne situation er Tønder området og Lolland-Falster.

\section{Tønderområdet}

Tønderområdet hører til blandt de såkaldte udkantsområder i Danmark. Tønderområdet ligger ud til Vadehavet, der strækker sig fra Den Helder i Holland til Blåvandshuk i Danmark. Vadehavet er verdens største estuarie, der sammen med menneskets påvirkning har formet det helt særlige landskab. Den tyske og hollandske del af Vadehavet kom på Unesco's verdensarvsliste i 2009, med opfordring til at den danske del også kommer på.

Landsbyerne i Vadehavsregionen er som helhed kendetegnet af en enestående sammenhæng med det specielle landskab samt af de mange relativt velbevarede huse og gårde, som stadig er præget af den regionale byggeskik. Mange af landsbyerne ligger præcist i overgangen mellem marsken og det åbne land. Som nævnt ovenfor vil de igangværende strukturændringer i landbruget betyde, at jordbrug bliver opgivet, og driftsbygninger bliver overflødige. Det vil således skabe færre brug med betydeligt større og nye landbrugsbygninger, end det vi allerede ser i dag.

\section{Hvilke muligheder har området?}

Kulturturismen er en af de sektorer, der ses nærmere på i regionen. Den vil i høj grad kunne fremmes gennem optagelsen af området på Verdensarvslisten, ligesom det igangværende arbejde med at gøre området til nationalpark vil fremme dette potentiale.

Det bør endvidere overvejes, om sommer-og fritidsbeboere er bedre end ingen beboere, når det gælder vedligeholdelsen af bygninger i 
landsbyerne. Der vil givet være et forholdsvist stort og købedygtigt publikum til husene, hvis de kan anvendes til fritidsformål.

En lang række fødevareproducenter i området har sluttet sig sammen i Vadehavsprodukter, der har til formål at støtte producenterne i deres arbejde og medvirke til markedsføring.

\section{Lolland-Falster}

Også Lolland Falster hører til blandt de såkaldte udkantsområder, der igennem en årrækkke har været præget af fraflytning og mange sociale problemer.

Lolland Falster er også et område i Danmark, der rummer alle former for kulturarv i rigt mål. Ikke mindst på Lolland er der velbevarede fortidsminder, der er middelalderkirker og ruiner, herregårde og herregårdslandskaber, industrimonumenter og meget mere. Lolland Falster har noget af Danmarks mest frugtbare jorde. Og måske det mildeste klima i Danmark.

\section{Hvilke muligheder har området for et fornyet erhverv?}

Området rummer med den rige kulturarv og de fine kystområder et enestående potentiale for fornyet turisme. Og med etableringen af Femern forbindelsen vil dette potentiale blive endnu større. Det er en forholdsvis velbevaret hemmelighed, også for indenlands turisterne i Danmark, at området har denne helt enestående kulturarv at byde på.

Området har selv skabt fødevarerprojekter der udnytter den gode bonitet og det milde klima. Der dyrkes æbler og kirsebær. Der avles geder, produceres ost, mælk etc. Og områdets ambition er at blive Danmarks førende produktionssted for kvalitetsfødevarer i Danmark - og måske i Nordeuropa.

\section{Hvad er Kulturarvsstyrelsens rolle i disse sammenhænge}

Kulturarvsstyrelsen arbejder i høj grad formidlende og i mindre grad regulerende. Kulturarvsstyrelsen kan ikke redde disse områder - og det er slet ikke vores rolle. Det er kun områderne selv der kan gøre det. Det nytter ikke at igangsætte projekter der ikke er bæredygtige på langdistancen. Og projekterne skal langt hen ad vejen komme "indefra". Projekterne skal over en årrække være økonomisk selvkørende. Men styrelsen kan påpege de potentialer der ligger i kulturarven:

- Vi kan påpege potentialer

- Vi kan være øjenåbnere

- Vi kan støtte lokale initiativer gennem dialog med politikere, embedsmænd og lokalbefolkning

- Vi kan støtte pilotprojekter økonomisk gennem de statsanerkendte museer

- Vi kan støtte områderne gennem dialog med andre statslige myndigheder 


\subsubsection{Från sagor till högteknologi - användningen av jordvärme i Island}

Gudjon Magnusson, kommunikationschef Reykjavik Energi, Island

\section{Jordvärme i naturen}

Jordvärme i Island kommer från värme som existerat sedan jorden bildades. I många områden når denna värme upp till markytan i form av varma källor eller gejsrar. Ofta förekommer vulkanutbrott med lavaströmmar och aska som följd. Island delas in i högtemperatur- och lågtemperaturområden. De källor man badar i ligger i så kallade lågtemperaturområden.

\section{Jordvärmen i Sagorna.}

När vikingarna kom till Island hade de inte någon erfarenhet av att använda jordvärme. Dock fanns en badkultur med torrbad där man värmde upp stenar, som i en bastu. I sagorna berättas det ofta om när man gick för att bada sig i de varma källorna. Många orter i landet har fått namn som syftar på de varma källorna: Laugardalur,Varmahlíd, Reykholt och Reykjavik. Ordet laug används ofta som namn på en ort eller ett ställe där man badade. Den första laug (källan) låg i Reykholt hos Snorre Sturluson. Den finns kvar än i dag. Egill Skallagrimssons sista ord var "vil ek fara til laugar" (jag vill nu gå och bada).

\section{Början till nyttjandet av jordvärmen}

Vad hände på medeltiden? Den finns ingen dokumentation om användningen av varma källor under medeltiden. Folket använde enbart torv för uppvärming av sina hus. Man tror att detta beror på kyrkans makt. Man ville helt enkelt inte tvätta sig eller använda resurser som var förknippade med dörren till helvetet - vulkanen Hekla.

På 1800-talet började man först utnytja jordvärmen för produktion av salt. Man tillverkade också svavel åt den danske kungen.

Två isländska vetenskapsmän argumenterade år 1753 för användningen av jordvärme. Bjarni Pálsson og Eggert Olafsson reste landet runt och borrade efter vamt vatten. Därefter gjordes inga nya borrningar i landet förrän 1929.

\section{Första värmeanläggningarna}

År 1901 värmdes det första huset i landet med geotermiskt vatten. År 1930 började man använda geotermiskt vatten till uppvärmning i Reykjavik. Detta skedde efter många diskussioner och stor oenighet. I dag värms $90 \%$ av alla hus i Island upp med fjärrvärme från den geotermiska energin. Islänningarna hade haft denna värme i mer än 1000 år innan man lärde sig behärska tekonogin för att kunna utnyttja den. Redan romarna hade denna kunskap och använde jordväme i sina badhus. Man kan fråga sig varför vikingarna, som var nere i Istanbul (Mikli- 
gardur) och såg turkarnas badkultur med jordvärme som resurs, inte tog med sig detta hem.

\section{Det ekonomiska värdet av jordvärme}

I ett land som inte har tillgång till ved som bränsle och ligger ganska långt upp i norr (61-66 grader nordlig bredd) med låg medeltemperatur, är tillgången till jordvärme en mycket viktig naturresurs.

Vid sekelskiftet 1900 var Island ett av de fattigaste länderna i Europa. 100 år senare var landet ett av de rikaste. Tack vare utnyttjandet av naturresurser som fisken i havet, vattenkraften och den geotermiska energin, samt bättre utbildning, har man kunnat förbättra livsvillkoren i landet dramatiskt.

Jordvärme går att finna i många länder som i dag har dålig ekonomi. Man kan säga att det är en utmaning för Island att hjälpa fattiga nationer att bättre kunna utnytja denna värdefulla resurs.

\section{Miljö och förnybar energi}

I Island har det pratats mycket om jordvärme som förnybar energi. Man hävdar att miljön inte påverkas av denna form av energi då man har möjlighet att ta bort alla ledningar och byggnader så snart man har slutat utnyttja energikällan. Det har också förekommit diskussioner om det kan finns en risk att göra slut på det geotermiska vattnet, dvs tömma den geotermiska behållaren. På dessa frågor har man olika svar och oenigheten bland forskarna är stor.

\subsubsection{Case Sunila - remarks on heritage and sustainable prosperity}

Tommi Lindh, intendent, Museiverket, Finland

- Alvar Aalto's heritage

- Industrial heritage

- Cultural heritage

- Sustainable architecture

- Sustainable industry

- Sustainable cultural property

- Sustainable architecture lasts longer and prospers

- Sustainable industry pollutes less and prospers

- Sustainable cultural property needs heritage to prosper

Sunila is Aalto's architectural heritage. Sunila is industrial heritage. Sunila is national cultural property. Sunila's architecture is not sustainable because the wood industry based in it is not. It pollutes the environment and doesn't have the prosperous cellulose markets anymore to continue its operation. Still the cultural heritage value is there and it needs the buildings to manifest itself. 


\section{What should we do?}

- Save the buildings even if they are empty because of the architecture?

- Find new uses which demand changes in the architecture?

- Tear everything down and make a good documentation before that?

\subsubsection{Economics and built heritage}

\section{Maire Mattinen, National Board of Antiquities, Finland}

The network called "Economics and Built Heritage" raises public awareness about the value adding potential of heritage, prepares a comparative programme and supports researcher networking. One interesting sector to study is the real estate markets - does the price depend on esthetic or historic value - or is the location the only meaningful actor? The aim is to show that the relationship between economics and built heritage is not one-dimensional but manifold. During the Ebheritageproject we've identified three basic approaches to the economic dimension of built heritage, while acknowledging that clear boundaries between them cannot be drawn.

\section{Built heritage as a subject of economic planning}

Several rigorous valuation methods are available, but there remains a theoretically inspiring, unexplored terrain to be studied.

In planning, the proper consideration of values attached to the built environment requires sufficient knowledge base of the built environment. There have been difficulties in integrating various approaches to the built heritage, such as archaeological surveys, art historical studies, cognitive mapping and architectural and environmental aesthetics. While appropriate comprehensiveness is missing, the evaluation criteria of the surveys lack clarity and transparency. More detailed statistics dealing with the built heritage and built environment are needed, too.

There are different value systems (aesthetic, economic, ethical, functional, historical, ecological, authenticity...) that cannot be fused into a single system. Thus, it should be handed openly to political decision making, which value system is afforded hegemony over the others and how much effort is to be put on searching for solutions that would meet different value requirements simultaneously.

In environmental impact assessment research, cost-benefit analysis is regarded as an aggregative method, since it translates differently derived value considerations into the uniform medium of money. This makes value judgment apparently easy: for different planning and development proposals we can deduce an aggregative price, the best being the one "least costly" for the built heritage (seen as a collection of "heritage items" with price labels). 


\section{Built heritage as a property in the urban and real estate market}

When built heritage is approached as a property in the market, the economic value is seen in terms of potential or actual monetary price in the urban and real estate markets. The focus is on how the different aspects of the built heritage, in different localized urban markets, contribute to the determination of the price of the estates and areas in the market. For example, the price value of an estate in the "Old Town" does not follow merely from its central location, but the surrounding historical area also has a role.

Concerning built heritage, the mechanisms of the urban and real estate markets are a rarely studied subject. In environmental eco-nomics, there have been some studies concerning readiness to pay for cultural heritage among people, by asking their readiness in relation to different built areas and buildings (the so-called stated preferences). Another approach is to examine the effect of the closeness of built heritage on the estate prices (the so-called revealed preferences), such as the impact of the cultural heritage objects or the old building stock on the apartment prices in the area.

We need more research on the effect of different ways of renovating cultural-historically valuable buildings (from reconstructive repairs to modernizing replacements) to the real estate market value of these buildings. Concerning historical areas, we need more information on how renovations and additions in single buildings, irrespectful to their historical character, influence the market value of the whole area. The market mechanism has a key role in the maintenance and development of our built heritage.

Planning negotiations on built heritage sites and areas are often biased, as, in the vein of economic analysis, the built environment is seen primarily as a private good. Awareness of and attention to the public good characteristics of the planned environment would offer a conceptual vehicle for bringing the values held by the public to the agenda, and for justifying public participation in the planning process.

\section{Built heritage as a resource (capital) for the economic livelihood of regions}

However, studies on the impact of built heritage to the local and regional economy are few, in comparison to studies on the role of cultural industry and services. There is a need for research concerning direct and indirect impacts on the local and regional economy, of investments made on built heritage. Especially the assessment and evaluation of the impact of regional development projects is needed. In our Economics and Built Heritage network we have noticed the lack of information on the motives and cause-effect chains behind and between different activities.

Mr Donovan D. Rypkema identifies the characteristics of successful heritage partnerships, and thereby he offers valuable guidelines for the forming of future partnerships in the maintenance and development of built heritage estates and areas. 
A subtheme on the relations between cultural heritage and regional economy, which is gaining growing interest, is economic impact analysis on cultural tourism. More clarity is needed in identifying the role of the built heritage as an attractor of the tourists' visits: to what extent does it function as a primary factor or a secondary one.

Among the indirect impacts of built heritage, its connections to local identity and self-image are often mentioned. The built environment has a central role in modifying the images we gain from different local and regional entities. We may draw on these images in place-marketing campaigns alluring tourists and new residents and enterprises. Correspondingly, a high quality built environment is likely to foster the local residents' rooting to their home towns and neighbourhoods. The maintenance and repair of the local built heritage can also be a direct source of local income, in the sense that it offers work for skilled local carpenters and caretakers. Evidently, there is a lot of undiscovered potential for the utilization of the built heritage as a source of local and regional livelihood. 


\subsection{Resa, bruka, bevara}

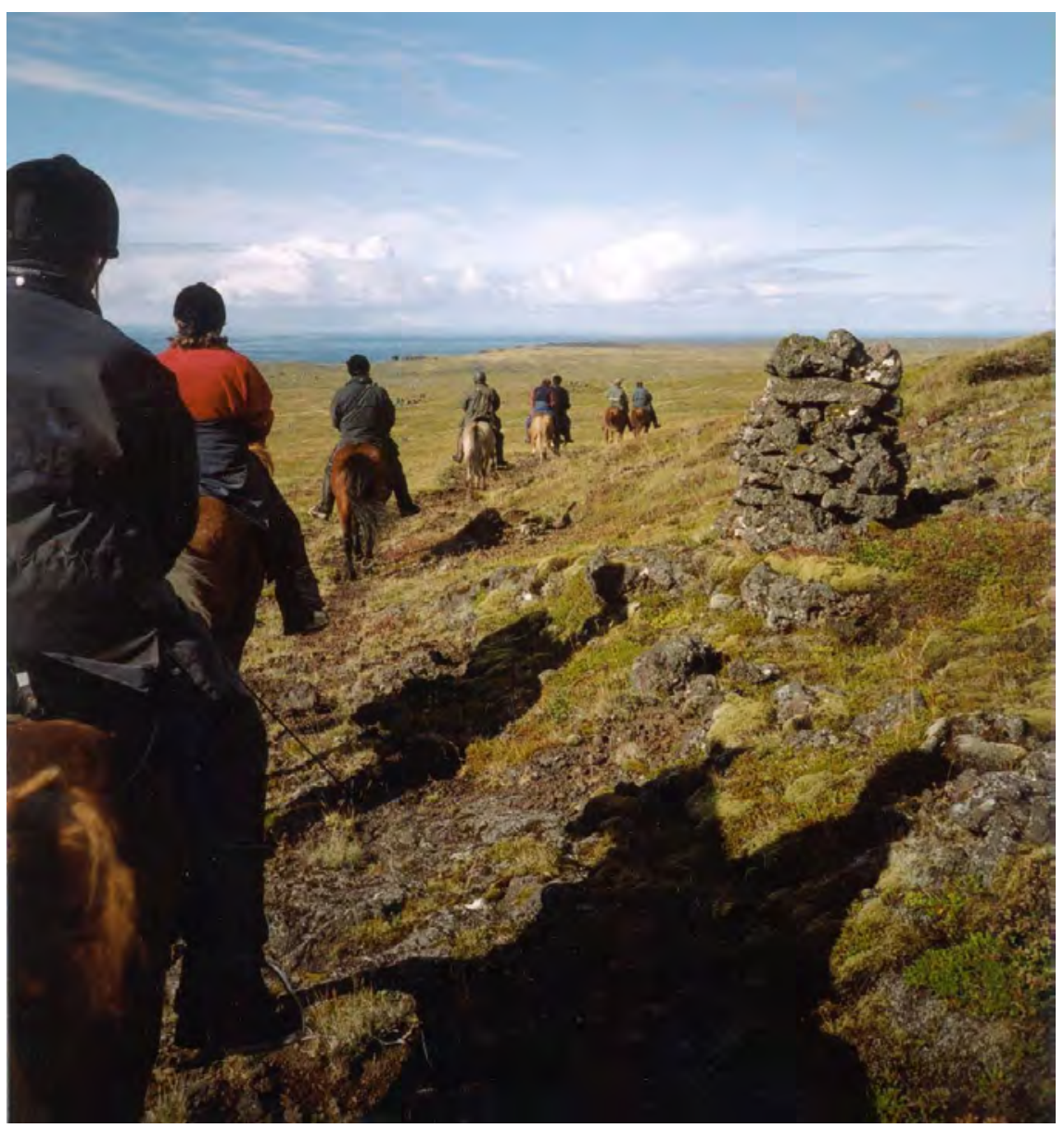

Natur- og kulturarv som ressurs for bærekraftig turistutvikling. Nordisk konferanse. Trondheim 6-7 september 2010

v/Re Plan, Hemsedal, Norge, oktober 2010 på oppdrag av Riksantikvaren og Direktoratet for naturforvaltning.

\subsubsection{Key note: Turismens betydning for bærekraftig samfunnsutvikling}

Bjørn M Bjerke, Næringslivets Hovedorganisasjon, Reiseliv, Norge

Dagens og morgendagens beslutninger bestemmer neste generasjons inntjening, omdømme og sikkerhet. Hovedmålsetting er at neste generasjon skal ha minst like god bedriftsøkonomi som i dag. Det krever at morgendagens reiseliv er ansvarlig og framtidsorientert med forståelse for sammenhenger og avhengighet mellom Bedriftsøkonomi, Samfunns$\varnothing$ konomi og Kultur. Natur og kultur viktigste råvare for reiselivet. Reiselivet er en kommersiell næring og må tilpasse seg samfunnets utvikling 
og skal ikke «utvikle samfunnet». Der reiselivet har en mulighet- har reiselivet ansvar. I et miljøperspektiv er det store utfordringer knyttet til flere turister - kontra begrense antall turister, og konsekvenser for bedroftsøkonomi, arbeidsplasser og samfunnsøkonomi. En utfordring er mangelfull forståelse av at en god reiselivsdestinasjon er et godt bosted. Tverrsektoriell samhandling må gis større prioritet.

Transport er en viktig faktor i reiselivet. Dagens transport-næringer ikke bygd for bærekraftig framtid. Næringen avhengig av internasjonal trafikk fra oversjøiske land. Vi kan ikke bare ha kortreist reiseliv.

Vi må ha bedrifter som kan bære utviklingen. God bedriftsøkonomi skaper større handlingsrom for å velge bærekraftige løsninger/tilbud.

\subsubsection{Europeisk og nordisk perspektiv på bærekraftig turisme}

\section{EUs mål og kriterier for bærekraftig turisme}

Lars Thykier, Danmark Rejsebureau Forening

EU sin politikk for å fremme bærekraftig og konkurransedyktig turisme er nedfelt i ulike rapporter:

- Tourism Sustainability Group (TSG), (2004) ble fulgt opp av rapporten "Action for more sustainable tourism" (febr 2007)

- Agenda 21 (oktober 2007): grunnleggende retningslinjer for bærekraftig europeisk turisme

- Lissabontraktaten (desember 2009) innfører et nytt rettsgrunnlag som utelukkende omhandler turisme for å styrke EU`s image som et av verdens ledende turistmål. Traktaten åpner for at EU kan støtte innsatsen i medlemsland sine turismesatsinger, især knyttet til bærekraft og konkurranseevne

EU's 3 mål og prinsipper for en bærekraftig konkurransedyktig europeisk turismeutvikling er; (ref EU kommisjonen 2007):

- Økonomisk perspektiv

- Bevarelse av natur og kultur

- Samfunn/sosial likhet og samhandling

EU vektlegger at det ikke skal være kultur og miljøhensyn alene, men også økonomisk attraktivt samt hensyn til sosiale dimensjoner som sysselsetting, stedet og regionen.

Implementering av bærekraft skal foregå innenfor 3 hovedfelt:

- Bærekraftige destinasjoner 
Kritisk suksessfaktor. Krever effektive strukturer og omforente partnerskapsavtaler mellom innkvartering- transport- attraksjoner og opplevelser, miljø og kultur, og på sikt innføring av indikatorer for å måle effekt.

- Bærekraftig næringsliv

Særlig skal SMB integrere bærekraft i bedriftene gjennom kunnskapsbygging, innsikt, datainnhenting, finansielle insentiver og veiledning, kriterieutvikling og belønningssystem. De skal forstå sammenhenger mellom sysselsetting-, samfunn-, natur-, miljø-, kultur- og økonomisk gevinst.

- Ansvarlige turister

Hvordan bevisstgjøre forbrukeren om bærekraftige valg? Kunnskapsspredning ved bruk av kreative kommunikasjonsformer og sosiale medier med stor påvirkningskraft på forbrukernes valg, bruk av ulike verktøy som: prising, regelverk, væremåter slik at kunde blir veiledet til å ta riktige valg, samt opprettholde en konstant etterspørsel til turistnæringen.

Agenda 21 ( 2007) har vektlagt en rekke krav og kriterier en må leve opp til:

- Helhetlig og integrert tilnærming til bærekraftig utvikling etter langsiktige planer

- Realistisk framdrift ,tempo og rytme på bærekraftig utvikling

- Integrere beslutningstagere i prosessene som skal ha basis i beste tilgjengelige kunnskap

- Minimalisere og administrere risiko

- Prisnivåer skal gjenspeile belastninger påført av forbruker og forurenser

- Sett nødvendige grenser/begrensninger og respekter dem

- Gjennomfør løpende undersøkelser/kartlegginger

EU's konkrete initiativ for å fremme bærekraftig og konkurransedyktig europeisk turisme:

- EDEN - markedsføring av utvalgte europeiske destinasjoner (European destinations of excellence)

- CALYPSO - Støttetiltak for å fremme reiseanledning til bestemte målgrupper i lavsesong innenfor EU landene.

- LISSABONTRAKTATATEN - gir kommisjonen adgang til politisk iverksatte initiativer innenfor turisme. 


\subsubsection{Bærekraftig turisme-status i Norge}

Ingunn Sørnes, Innovasjon Norge.

Norsk reiselivsstrategi sin visjon fra 2007 fastslo: «Norge - et bærekraftig reisemål». Den nasjonale merkevaren er «Powered by nature». Innovasjon Norge(IN) har konkret fulgt opp strategien gjennom prosjektet «Bærekraftig reiseliv 2015» (BKR). 10 definerte bærekraftprinsipp er bygget på definisjonen til UNWTO (United Nations World Tourism Organization). Prinsippene gir god sikring og garanti for at kultur- og naturarvsinteresser er en viktig del av det kommersielle, norske reiselivet. Prinsippene styrker verdien av ressursene til mange små virksomheter rundt i landet. Erfaringene så langt er at det er sentralt å bygge kunnskap og nettverk mellom natur- og kulturarysmiljoene og turistnæringene - og i tillegg ha en sterk kobling til offentlig og privat sektor i lokalsamfunnene.

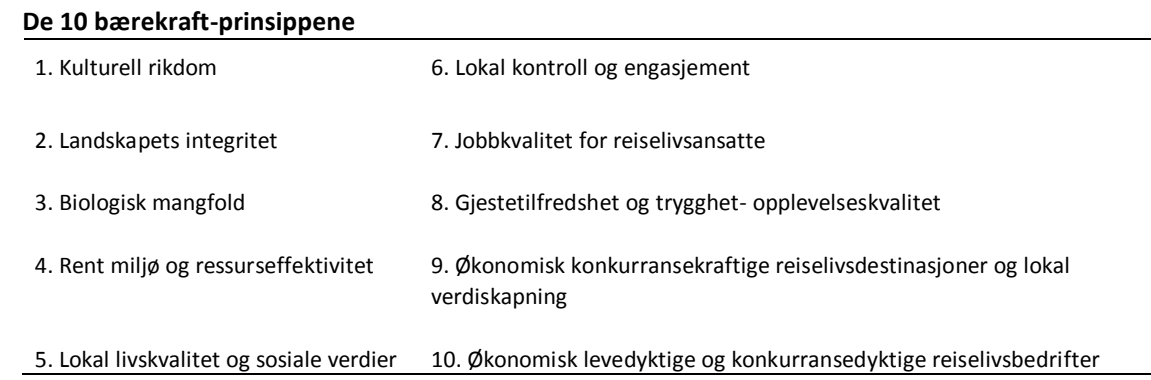

IN har ansvaret for sertifiseringsordningen «Norsk Økoturisme». IN sin reiselivsseksjon utøver den nasjonale turistmyndighet, samtidig som IN initierer og får rammevilkår til en rekke store turistrelaterte utviklingsprosjekt og pilotprosjekt. Norges har som ikke EU medlem, muligheten til å ta raske beslutninger. Arbeidet foregår i samarbeid med IN, NHO Reiseliv og Vestlandsforskning (FoU).

Bærekraftig reiseliv 2015 er organisert med 3 hovedoppgaver:

- Involvere reiselivsnæringer i 6 bransjegrupper som arbeider fram: status, mål, tiltak og indikatorer

- Pilot destinasjoner - teste kommersielle konsept for et bærekraftig reiseliv med erfaringsinnhenting og metode for gjennomføring, samt frivillige fellesgodefinansieringsordninger

- Integrere bærekraft i IN sitt arbeid innenfor markedssamarbeid, finansiering, profilering og kompetanse

Operasjonalisering av bærekraftprosjektene vil skje fortløpende:

- Kompetanseprogram (fra 2011) /Miljøsertifisering av reiselivsbedrifter er i sterk vekst 
- Green Travel - markedsføring og profilering av områder/bedrifter med bærekraftig profil. www.visitnorway.com. Synlig for konsumentlett å velge

- Utarbeidelse av verktøy og metoder (miljøledelsesverktøy)

- Finansiering av tiltak og spesifikke utviklingsprosjekt i de ulike bransjene innenfor reiselivsnæringene

\subsubsection{Bærekraftig turisme - status i Sverige}

Agneta Florin,Tillväxtverket

Tillväxtverket er den svenske stats turistmyndighet. Visit Sweden har primært markedsføring som hovedansvar. Tillväxtverket har utarbeidet 2 rapporter vedr. økoturisme og bærekraftig turisme, og deltok i utviklingen av «Naturens Bästa».

Erfaringsgrunnlag fra Visit Sweden er nyttig for videre utvikling av innenlandsturisme, men ikke tilstrekkelig for eksportmarkedene. Den svenske stat har gitt Tillvâxtsenteret oppdraget med å utarbeide strategi om turismens utvikling. Det avdekket behov for bedre kvalitetssystemer hos leverandører av reiselivstjenester/opplevelser. Prosjekt gjennomføres nå i Västra Götaland. Forprosjektet ble valgt som en pilot for kvalitets-og bærekraftsutvikling med hjelp av skotsk kompetanse. Erfaringer fra prosjektet er tenkt overført til nasjonalt nivå. Dette kan bli en driver for bedrifts-og destinasjonsutvikling.

\subsubsection{Bærekraftig turisme - status i Finland}

Kari Hallantie, Forststyrelsen

Finland sin turiststrategi bygger på ren natur og finsk kultur. Forststyrelsen forvalter $1 / 3$ av Finlands landareal og en viktig aktør i diskusjonen. På 1990 tallet var det ikke tillat $\mathrm{m}$ ferdsel i nasjonalparkene. Dette er opphevet og i dag utarbeides naturturismeplaner for hvert verneområde som avklarer hvor, når og hvorledes områdene kan benyttes til turisme, finansierer tilrettelegginger og gir rådgivning til bedriftene om mulig produktutvikling i verneområdene. Reiselivsbedrifter som benytter verneområdene må binde seg til en avtale med Forststyrelsens 9 prinsipp for bærekraftig turisme. Turisme er ikke en trussel for verneområdene, men en viktig samarbeidspartner. Målet er "joint action at destination level". Finland har utviklet verktøy for samhandling mellom ulike aktører/sektorer. Det foreligger en ny utviklingsstrategi for samarbeid kultur og turistaktører på lokalt nivå med mål om felles produktutvikling og markedsføring, samt opplegg for samhandling natur og kultur, myndigheter og næring. Den sosial holdbarheten betinger at turismen er forankret i lokalsamfunnet. 
Besøksundersøkelser gjennomføres i verneområdene med måling av besøkstall, ringvirkninger for lokalmiljø med sysselsettingseffekt og økonomi. Verdien av lokaløkonomi viktig å måle og dokumentere.

Eksempel: I Kvarken skjærgård i Østerbotten, nasjonalpark og Finlands første wold heritage park, er det gjennomført en visjonsprosess som ivaretar innbyggerne og besøkende.

\subsubsection{Bærekraftig turisme - status i Danmark}

Lars Thykier, Danmarks Rejsebureau Forening

Danmarks nasjonale strategi for bærekraft er «Fælles fremtid- udvickling i balance» fra 2002 og basert på 8 prinsipp. Ingen målrettet politikk eller nasjonal plan for bærekraftig turistutvikling, men en rekke private initiativ og sertifiseringsordninger som: Den grønne nøgle (innkvartering), Blå flag (rent hav og kystmiljø), Co2 kompensasjonsordninger for flyreiser.

Danmark har behov for å få definert en nasjonal strategi og målrettet politikk med konkret handlingsplan for bæredyktig og konkurransedyktig turistutvikling. Gjerne politisk som kan påvirke regionene, destinasjonene og bedriftene, slik at politikk omsettes til konkrete initiativ på nasjonalt nivå.

Få utviklet konkurransebarometer, policyutvikling av konkrete produkt, etablere incitamentskapende rammevilkår som skatter, spesielle tilskudd på innkjøp etc, samt stille krav til turistnæringen og til forbrukerne om mer bærekraftig valg og adferd.

Det er for lite samhandling mellom sektorene natur og kultur og reiseliv til en helhetlig dansk bærekraftig turistutvikling.

\subsubsection{Bærekraftig turisme - status på Island}

Elias Bj Gislason, Icelandic Tourist Board

Bærekraft innenfor turisme først nevnt i 1985. En ny turistlov vedtatt i 2005 med 4 hovedprinsipp:

- Islandsk kultur

- Bevaring av miljø/natur

- Kunnskapsbasert turisme

- Ivareta og sikre kundens interesser

Nasjonal reiselivsstrategi 2006-2015 har 3 bærebjelker:

- Natur

- Kultur

- Kunnskapsbasert utvikling 
For å kartlegge eget ståsted er det gjennomført 5 tålegrense-studier på ulike steder med fokus på:

- naturen/fysiske omgivelser

- Sosio-kulturelle sammenhenger (turister/lokalbefolkning/kulturelle aspekt)

Sertifiseringsordinger har hovedsakelig vært Green Globe. Usikkerhet knyttet til videreutvikling av og varighet på Green Globe. Icelandic Tourist Board innhentet og vurdert ulike sertifiseringssystem med høy fokus på kvalitetssikkerhet og bærekraft. Valget falt på sertifisering basert på New Zealand sitt Qualmark. Estimatet er at det skal utarbeides opp til 30 kriterier tilpasset de fleste aspekt av Islands turisme, inkludert natur og kultur kriterier. Islands turisme er mangedoblet siste 50 år, fra 4.400 gjester i 1950 til nærmere 500000 i 2009. Gjesteundersøkelser viser at Islands "brød og smør" er naturen og kulturen hele året. Islandic Tourist Board sin rolle innenfor bærekraftig turisme er å gi økonomisk tilskudd til prosjekt, samt initiere oppbygging av nye ferieopplevelser rundt i landet innenfor natur-kultur-historie(saga).

\subsubsection{Bærekraftig turisme - status i Færøyene}

Per Hansen, Udenriksministeriet

Færøyene kåret til den vakreste øygruppen i konkurranse med $110 \varnothing y-$ grupper fra hele verden. I 1990 ble Færøyenes Turistråd etablert, og i 1992 kom den første utviklingsplanen. Turismens hovedplan var restriktiv med stor vekt på naturbevaring i sårbare naturområder. I 2000 ble ny generalplan og lov for Turistrådet vedtatt, med mandat til markedsføring og til å utvikle øyene. Høy prioritet på detaljerte planer med lokal forankring og lokal produktutvikling ved å bruke naturen. Viktig samspill natur og mennesker. Utfordringer knyttet til bruken av naturen førte til designhåndbok i skilting som alle kommuner skulle følge. Visningsturer ble gjennomført for å øke lokalbefolkningens kunnskap om eget land og de verdier som er i nærmiljøet, skape stolthet og bevissthet. Det er diskusjoner knyttet til tålegrenser, fra for eksempel cruise og campingturisme og sårbarhet til fuglefjell når båtene seiler for tett på. Turistrådet initierte en pris til best bevarte bygd. Kunnskap- og erfaringsutveksling har vært nyttig for å kunne ta i bruk «best practice». 


\title{
8.3.9 Bærekraftig turisme satt i en helhetlig politikk for regional-og lokal samfunnsutvikling
}

\author{
Hvordan kan en strategi for bærekraftig natur-og \\ kulturarvsturisme anvendes som utgangspunkt for regional vekst \\ Johan Loock, Länsstyrelsen i Jämtland, Sverige
}

Prosjektet er et Regjeringsoppdrag fra 2005 og revidert i 2008, med fokus samarbeide mellon natur, kultur og bærekraftig regional vekst og utvikling. Det ble nedfelt 6 visjonære punkt og 5 konkrete tiltak i en strategi for utvikling av bærekraftig natur-og kulturturisme. Av konkrete tiltak kan nevnes: Identifisering av attraksjoner og mulige turistutviklingstiltak i vernede natur- og kulturmiljöer, kompetansebygging, markedsanalyser, produktutvikling, infrastruktur for turister, formidlingstjenester av natur- og kulturarven, samt utvikle system for minisere konfliktinivå. Området VålådalenSylarne ble utvalgt, er et naturreservat og kan bli en nasjonalpark.

Erfaringene fra prosjektet er:

- Betydningen av samarbeid og dialog. «Världens starkaste ekoturismdestination» - her viste det seg vanskelig å ta betalt for tjenester, det å nå nye marked og nye produkt, samt konflikter om målene. Burde Länsstyrelsen ha en koordineringsperson innenfor turisme? Reinsdyrnæringen hadde en nøkkelrolle. Vil en nasjonalpark bli trussel eller mulighet? Prosjektet var givende men vanskelig, samtidig pågår mange prosesser i fjellregionene som gjør det vanskelig å ha oversikt

- I et langsiktig perspektiv må det i samarbeid med regionale myndigheter være større innsats på kunnskaps- og utviklingsdelen

- Alle aktører på stedet/destinasjonen må se sin rolle og ansvar for å få den til å fungere

\subsubsection{Turisme integrert i lokalsamfunnsutvikling.}

\section{Nærøyfjorden som case}

Ivar Bjarne Underdal, Nærøyfjorden Verdsarvpark, Norge

Formål: Verdensarvparken skal utvikle eierskap til landskaps- og kulturverdiene og aktivt fremme internasjonale verneverdier gjennom lokal økonomisk, kulturell og identitetsmessig utvikling.

Nærøyfjorden Verdsarvpark er regulert ved en langsiktig strategi- og handlingsplan. Bredt og forankret samspill vises gjennom parkplanens oppgaver; Styrking av primærnæringene, natur- og kulturbasert næringsutvikling, stedsformidling, vertskapsutvikling og læring, skjøtsel og tilrettelegging av naturen, samt styrking av felles identitet og merkevare

Hva gjør reiselivet som kraft med lokalsamfunnet- hva er trussel og hva er muligheter? Har lokalsamfunnet en påtitter-rolle? Og er eventuelt 
dette negativt? Det er en positiv opplevelse å bli sett, men belastende på bli sett på. Påtitter- det å bli sett- kan også være en strategi for å bevare og utvikle, bli stolte av bygda og verdiene den representerer.

Ca. 500000 turister kommer til området i løpet av en begrenset periode på året. Flåm/Aurland/Nærøyfjorden er en av få regioner som har andre enn sitt regionale marked som det største. Antall turister er mindre interessant enn at næringslivet har en sunn økonomi med evne til å ta finansielle løft på destinasjonen. Lokalbefolkningen må få eierskap, få kunnskap og mestre vertskapsrolla som er en forutsetning for bærekraftig samfunn. Økonomisk verdiskaping skjer gjennom å verdsette produktene som tilbys, og kulturell og sosial verdiskaping skjer gjennom å løse ut ressurser i enkeltmennesket.

Destinasjonen har ett sett av små lokale aktører, og noen få eksterne investorer/eier. Suksesskriteria er god dialog. Aktørene må ha ett system for samhandling. Mulighetene må dyrkes fram, støtt positive initiativ. Skap synlige resultat lokalt. Næringslivet må se ansvaret for samfunnsøkonomi tilsvarende bedriftsøkonomi. Samfunnet og naturen er råvaren. Faren oppstår når eksterne eiere/utvikler ikke har langsiktighet, ikke forplikter seg. De små aktørene har ikke finansiell evne til å være en finansieringsaktør på destinasjonen.

Nærøyfjorden - world heritage - er et godt eksempel på velfungerende partnerskapsprosjekt.

\subsubsection{Formidling og guiding - merverdi gjennom innlevelse og forståelse}

\section{1 fortellinger om Danmark}

Morten Stenak, Kulturarvsstyrelsen, Danmark

1001 fortellinger er en elektronisk dataformidling om Danmark med 4 formål:

- Oppdragende om Danmarks historie; bygningar, fortidsminner, kulturmiljøer

- Gi info om alternative opplevelsesmuligheter

- Synliggjøre kulturarven som ressurs for utvikling

- Aktivere lokalbefolkningens viden om deres hverdags landskap og kulturarv

Vil fungere som en «kulturarvs facebook», der både dansker og utlendinger kan bidra med fortellinger, kommenatrer og fotos. En web-site med svært mange plattformer: mobil/i-phone, widget/iframe, webservice, POI til GPS, Facebook, Dagensfortælling, YouTube, Google adwords og optimering til søkemaskiner. Tidsplan: 2007-2010 beta lansering. Fra 
2011 Drift. Kostnad: nærmere 10 mio. offentlige DKK. Mange store samarbeidspartnere står bak prosjektet.

\subsubsection{Nordic Blue Parks}

Mari Salminen Museiverket, Finland

Konseptet Nordic Blue Parks formidler undervanns natur-og kultur arv.

Skipsvraket Gustav Adolf gikk ned i 1788 og ble funnet i 1995. Parken åpnet i 2000 som den første i Baltiske hav. Teorien rundt konseptet er: en kan ikke bevare om en ikke har kunnskap om hva man har. Prosjektsamarbeidspartnere er Sverige, Norge, Danmark og Finland med støte fra Nordisk Ministerråd.

Andre vrak som mulige Nordic Blue Park konsept er registrert i de 3 andre landene. Det foretas risk analyse; både natur-og kulturarvsmessig. Foreløpig mangler et overvåkingssystem.

Stor grad av tilrettelegging ved skipsvraket med informasjonstavler og «rutebeskrivelser». Majoriteten av de besøkende er vrak-dykkere . For besøket er det viktig samt at tilbudet er sentralt nær Helsinki. Fremtidige planer inkluderer videre tilbud til dykkere og til ikke dykkere, samt bruk av sansene.

\subsubsection{Kulturturisme for barn - saga, natur og opplevelser}

Gudbjørg Gunnarsdòttir, Snæfellsjökull National Park, Island

Prosjektet Saga og Jøkull samarbeid mellom 10 turistforetak innen opplevelser og events, historier knyttet til verdiene i natur og kultur, bygget rundt historien om jenta Saga(historien) og gutten Jøkull (isbreer). Barna får en mappe på første besøkssted på en reise underveis til de andre 9 stedene. 5000 mapper er produsert. Suksesskriteria: de gode opplevelsesstedene fantes, det ble laget et nye produkt til familier med kreative og aktive deltagere, og det er med offentlige økonomisk støtte. Prosjektet vil gå videre, bygge på verdiene i natur og kultur. Lærdom: dette var en kreativ produktutviklingsprosess som tidvis ble opplevd kaotisk, den tok tid, men den var morsom. Prosjektets bærekraft ivaretar alle 3 aspekt:

- Samfunn: Skaper nye arbeidsplasser

- Økonomi: flere gjester til Island, de blir lengre da tilbudet er bredere

- Miljø: tar fram verdiene i natur og kultur 


\subsubsection{Innovativ Fjellturisme- triple helix- samarbeid næring, forvaltning, forskning}

Kjell Gunnar Dale, Norge

Organisering: 5-årig prosjekt for 7 fjelldestinasjoner med sterk offentlig finansiering. Visjon er at gjøre fjellturisme lønnsom og helårlig med høy attraksjonskraft på utvalgte internasjonale turistmarked. Målet er at etablere fjellturismeklynge $\mathrm{m} /$ innovasjon rettet mot internasjonal sommerturisme som grunnlag for helårsturisme. 4 strategiområder:

- Kompetanse /nettverk

- Produktutvikling/entrepenørskap

- Konseptuering/pakking/salg

- Offentlige rammebetingelser

Forankring og eierskap ble sikret gjennom bred deltagelse fra næringsaktører, kommuner, offentlige utviklingsaktører, FoU aktører, destinasjoner, rådgivingsmiljø. 75 personer i prosessledelsen. Kostnad 70 mio. NOK, hvorav 40 mio. fra næringen hovedsakelig verdien på egeninnsats.

I følge evalueringen hadde $82 \%$ av bedriftene satt innovasjon på dagsorden i egen virksomhet. Viktigste tiltak har vært årlige internasjonale studieturer til nasjonalparker/ landskapsvernområder/ oppleveser der naturen er viktigste ressurs, samt en årlig fjellturismekonferanse.

Identifiserte flaskehalser for økt verdiskaping:

- Fellesgodefinansiering (bør ikke være basert på frivillighet)

- Bedre grunneiersamarbeid på fjelldestinasjoner

- Fokus på den visuelle destinasjonen (arkitektur, estetikk, arealløsninger)

- Utredet ny arealmessig planleggingsmodell for fjellturisme

- Utarbeidet norsk modell for partnerskapsregime (etter erfaringer fra Whistler i Canada)

- Problematikk og behov for enhetlig skilting av stier, sykkelveier, skiløyper etc. Utarbeidet felles mal for skilting og vanskelighetsgradering av stiene. Håp er at denne skal bli en nasjonal standard

Erfaringer etter 5 år:

- Stort kunnskapsbehov. Erkjennelse at Norge har lite reiselivsforskning

- Samordning av markedsføringpå tvers av næringer/sektorer/grenser. Konkurrentene dyktigere, selv om vi har like gode produkt

- De naturgitte forutsetningene er for svakt kommersialisert til å bli inntektsbringende

- Stedene med sterke destinasjonsselskap ble vinnerne 
- Styrking av de største aktivitetstilbyderne positivt for de mindre, og vil gi større attraksjonskraft til destinasjonene

- Klyngen er nå 6 år - og er fortsatt et spedbarn

Anbefalinger:

- Økonomiske virkemidler må bli enklere og mer fleksible

- Reiselivet trenger lang tid på visjonære prosjekt - ikke kjør for korte prosjektperioder

- Bygge system for erfaringsoverføringer og anbefalinger

- Reiselivet trenger et bredere FoU miljø som er mindre personorientert enn dagens situasjon i Norge

Kan modellen overføres til et Nordisk samarbeid? Er det politisk vilje til å våge å satse på de store i forhold til de mindre? Nasjonalparker og verdensarv områder bør ha en egen strategi for reiselivssatsinger, en egen turismeplan.

\subsubsection{Naturens Bästa. Økoturisme som marked og konsept}

Per Jiborn, Naturens Bästa, Sverige

Definisjonen av økoturisme: kommersiell turisme som skjer i naturen. Naturens Bästa ble lansert under det internasjonale ekoturiståret 2002, med Visit Sweden og Ekoturismeforeningen bak sertifiseringen. Sertifiseringen bygger på 6 prinsipp; destinasjonens natur-og kulturarv, lokal forankring, miljøhensyn, aktivt naturvern og kulturpleie, guidekvalitet samt verdskapsrollen og profesjonelle bedrifter. En hyggelig måte å reise på med krav til gjestens adferd, og med en leveranse lokalt forankret i samfunn, natur og miljø. Vertskap og kvalitet følges opp. Ca. 250 arrangement er kvalitetssikret, og ca 80 arrangører og leverandører er kvalitetsmerket. Det stilles krav til hele bedriften, til produktene og med spesialkriterier knyttet til opplevelsesprodukter som jakt, kanopadling, hest m.fl.

Kvalitetsmerking som et verktøy:

- Gjennom markedsføring synliggjøre kvalitetsmerkede tilbud for gjest som vil få en konkret valgmulighet

- Mindre bedrifter når lettere ut til markedene gjennom felles markedsføring

- Naturen skal ha en økonomisk verdi

Kvalitetsmerkingen setter spor:

- Nye arrangører og bedre lønnsomhet

- Synliggjøring av en hel økoturisme-bransje 
- Produktutvikling og nye målgrupper ved hjelp av pakketering, markedsføring og booking

- Stimulert til nye ansvarlige reisemåter. Svensk økoturisme er i vekst.

- Nye strategiske samarbeidspartnere for bedre spredning i markedene er etablert

Utfordringer:

- Markedsbudsjettene for små til å gjennomføre profesjonell markedsføring slik at en kan oppnå bedre kommersiell gjennomslag i markedene

- Den enkelte bedrift er liten, har svak økonomi og finansieringsevne utover små løft i egen bedrift, finansieringstiltak støttes med 60-70\% av det offentlige, Øvrige dekkes av bedrift. Mål: selvfinansiering

- De store aktørene i turistnæringen fokuserer lite på reiseanledning til gjestene. Det må bygges opp større bevissthet som kan nyttes til bedre produkttilrettelegging og markedsføring

- Bedriftene bruker ikke merkingen i egen markedsføring

- De beste bedriftene lar seg merke og klarer å utnytte dets verdi, de som ikke bruker merket blir oftest ikke bedre

\subsubsection{Synergier og dilemmaer - bruk og vern}

\section{Gjenoppbygging av en forlatt bydel på Færøyene \\ Mayfinn Nordoy, Færøyene}

På øya Koltor ligger noen enestående trebygninger, helt uten betydning for forståelse av byggeskikk i Norden eller i Nordeuropa for øvrig. I 1994 ble øya fredet som en av Færøyenes fremste kulturarv, og i dag er det planer om å etablere området som nasjonalpark. Bygningene ligger i 3 klynger: Musealt område/forsamlinger og kursvirksomhet/Turisme m overnatting og bespisning.

Bebyggelsen skal tilbakeføres til sitt opprinnelige uttrykk anno 1850. Også innmarken (bøen) blir en del av fredningen med sine spesielle mønstre på grunn av korndyrkingsmetodene. Steingjerder skiller innmark og utmark (hagin). Trehusene er omkranset av steingjerder for å beskytte det dyrebare treet som i all hovedsak er drivved fra Russland.

Stedet ivaretar bæredyktig utvikling på flere felt; jordvarme, batteri til EL forsyning, økologisk landbruk, selvforsynt, nasjonalpark, bevaring av gamle færøyske husdyrraser. Turismen skal være en tilleggsnæring til de tradisjonelle inntektene.

Prosessen for å komme gjennom ulike instanser har vært tung. Erfaringer viser at spesielt 2 forhold er avgjørende: eierskap og økonomisk plattform for framtidig drift. Det siste er samtidig grunnlaget for annen del-finansiering. Følgende elementer bør vare avklart før oppstart: 
- Eierskap

- Økonomi for daglig drift

- Registrering og oppmåling av eksisterende forhold

- Endelig utseende

- Tillatelser fra myndighetene

Bæredyktighet er et spørsmål om å velge kvalitet framfor kvantitet. Det å velge det lokale framfor det globale - det å velge historien framfor standarden.

\subsubsection{Eksempel på produkt hvor varsomhet overfor forstyrrelse av dyreliv inngår}

Per Jiborn, Naturens Bästa, Sverige

Kulturbevaring og naturhensyn er en av Naturens Bästa sine 6 grunnprinsipp. Alle godkjente arrangører har konkrete prosjekt innen naturhensyn eller kulturarvinnsats. Utfordringer er knyttet til konkrete tiltak på disse områdene. Dette er å betrakte som et pionerarbeide, der bedrifter må samarbeide med ideelle organisasjoner og myndigheter. 5 prosjekt er kjørt; for eksempel bevaring av urskog og fuglesafari med ringmerking og oppsett av fuglekasser; jo mer fugler jo bedre safari.

De første erfaringene viser:

- Bedriftene bør ha en egeninteresse og eie innsatsen

- For få ser synergieffekt av bevaring av naturen - både myndigheter og naturvernorganisasjoner vil hindre kommersiell virksomhet og det at reisen til destinasjonene påvirker klima

- Det er ikke ført strategiske samtaler på tvers av næringer, sektorer, myndigheter og organisasjoner.

\subsubsection{Praktiske erfaringer og strategisk tenking i kryssfeltet turisme, kulturarv og opplevelser}

Peter Kvistgaard, Ph.D, ekster lektor Aalborg Universitet, Danmark

Turisme er markedet, kulturarven er innholdet- opplevelser er middelet. I kryssfeltet der disse 3 møtes er opplevelsesrommet som er fylt med verdier for dem som er der. Det hele handler om verdier - og verdiopplevelsen er subjektiv for den enkelte. Samtidig som verdibasert destinasjonsutvikling bør bli en suksessfaktor.

Opplegget er basert på 45 analyser av opplevelsesrom i Danmark og Tyskland siste 3 år, og tar utgangspunkt i stedets egenart innen historier, mennesker, natur, utvikling; med andre ord destinasjonens identitet. 
Falster er benyttet som case der det er gjennomført prosess med analyser, strategiutvikling over til utviklingsplan med konkrete mål. Flere enn 100 aktører var involvert; næringsliv, lokalbefolkning, politikere og kommunal forvaltning. En destinasjon blir både en forretningsmodell og et sted å bo. Integrert destinasjonsutvikling tar utgangspunkt i selve destinasjonen, aktørene på stedet og gjestene. Verdibasert destinasjonsutvikling som segmenterer interne og eksterne markedsforhold på en fokusert måte opp mot destinasjonens verdisett, både de uklare og de tydelige, slik at de fokuserte verdiene blir satt sammen med de fokuserte markedsforholdene, vil kunne utvikle en opplevelses økonomi med sterk intern integrasjon og sterk ekstern differensiering (me alone).

Erfaringer tilsier nå at lokal kulturarv engasjerer og involverer, etterspørsel etter kulturopplevelser vokser i Danmark så vel som i Europa. Kulturarv blir tilsynelatende stadig viktigere både som et tilbud og $\mathrm{i}$ form av etterspørsel. Allikevel har ikke kulturarven en fremtredende plass i integrasjon i danske kommuners strategiarbeid. Det er svak eller ingen tverr sektoriell samhandling i Danmark. 


\subsection{Natur- och kulturarvskraft}

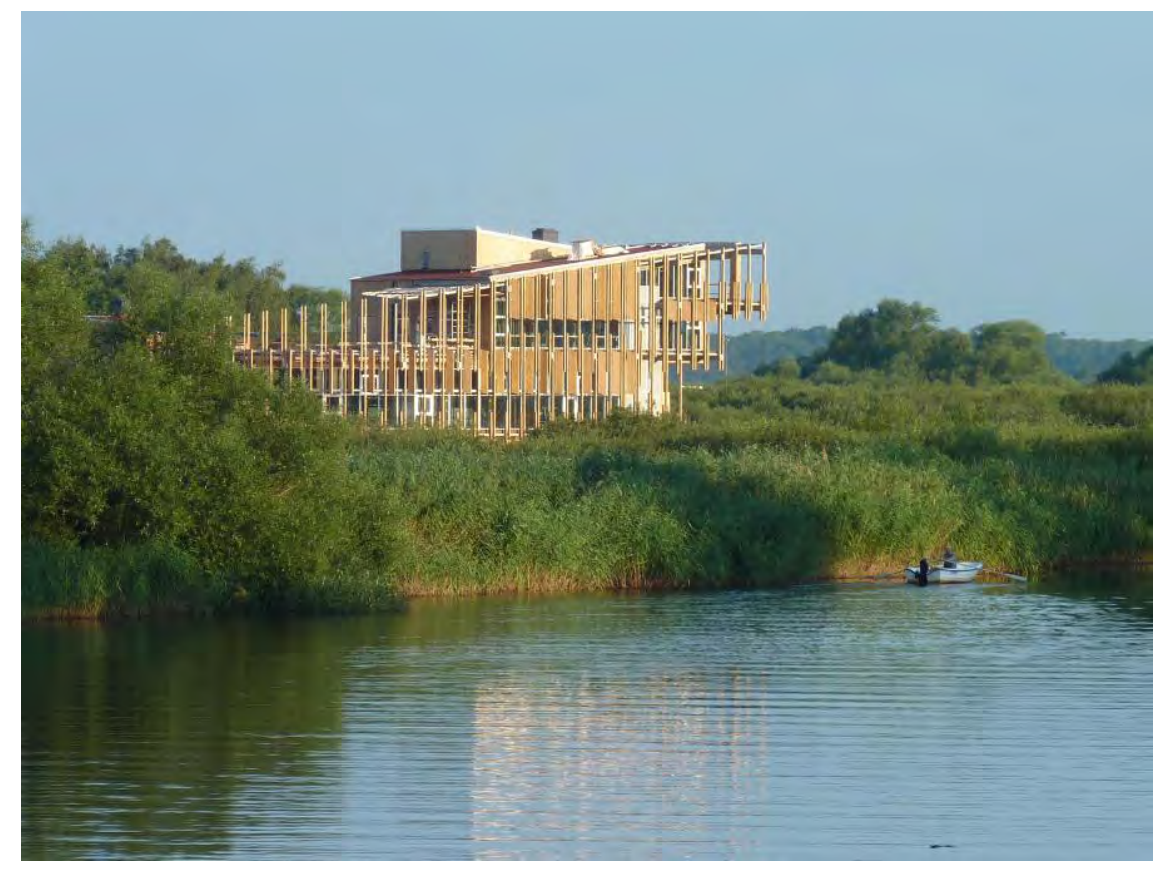

Nordisk workshop om natur och kulturarv som resurs för hållbar utveckling och tillväxt. Stockholm, den 26 oktober 2010

\subsubsection{The Nordic Landscape: Manifestation of diversity, Resource for Growth}

Kenneth Olwig, Professor, Landscape Planning and Heritage, SLU-Alnarp, Sweden

The Danish botanist and geographer, Joachim Frederik Schouw was not just a world renowned physical scientist, he was also passionately involved in the Scandinavian movement to bring democracy and development to Norden. In 1844 the organization called the Scandinavian Society, which he helped found, published a speech by him called Scandinavia's Nature and People in which he said:

"Denmark's nature is... not Scandinavian in the narrow sense, it is more similar to the German than to the Norwegian or Swedish. But then one should also conclude that the Danish people are more German than Scandinavian? This would be so if it were the case that it were true that a people's character is determined by, or is significantly dependent upon, the nature of that land which the people inhabit... [The character of folk] does not have its foundation in the land's soil or climate, it has its soil, its intellectual soil in History, out of which it springs, - has its intellectual climate in Language, in which it lives and moves." 
For Schouw, and the movement he helped start, the key to Nordic democratic social and economic growth was the heritage of the landscape understood as a place, or regional arena (e.g. Värmland, Aaland, Jutland, Trondelag, Savolaks), within which the people of the north had historically shaped their polity and its environment according to customary "landscape law" - often as formalized by representative bodies like the ting. Thus, even though the raw nature of the Northern peoples differed, they did have a shared cultural heritage that had shaped its peoples and nature as landscape. Today, the Nordic countries have achieved both democracy, socio-economic and urban growth, and Nordic cooperation regularly brings us together. Another reminder of this common landscape heritage is the pan-Nordic common right of access that gives, to varying degrees, the Nordic peoples an internationally unparalleled recreative use right to the land, also in urbanized areas. As a use right, however, it also forms the customary basis for people's identification with, and care for, these landscapes' cultural and natural heritage. Economic growth and urbanism has created new challenges for Nordic cultural and natural heritage policy, at the same time, however, as the heritage of democracy and shared environmental concern, left to us by Nordic pioneers like Schouw, provides a common resource for a future in which Norden has increasingly become a part of a Europe which is larger than the European Union.

The Council of Europe has recently promulgated the European Landscape Convention. Its definition of landscape, which resonates with the traditional Nordic landscape, is: "an area, as perceived by people, whose character is the result of the action and interaction of natural and/or human factors." According to the ELC: "the landscape contributes to the formation of local cultures and [...] it is a basic component of the European natural and cultural heritage, contributing to human well-being and consolidation of the European identity." This landscape is, furthermore, "an important part of the quality of life for people everywhere: in urban areas and in the countryside, in degraded areas as well as in areas of high quality, in areas recognised as being of outstanding beauty as well as everyday areas." Thus, much as the landscape provided a basis for Nordic identity in Schouw's pre-industrial era, it is likewise providing such a basis for a more urbanized European identity today. The ELC arguably reflects major trends in Europe and the world that affect everything from the consumption of foods and goods to the choice of tourist destination. Our rich heritage in this area should thus be able to give Norden an important leadership strength in developing the natural and cultural heritage of landscape, both for sustainable social development and well-being, and for economic growth in rural, peri-urban and urban areas. 


\section{Summary}

The Nordic project Natur och kulturarv som resurs för hållbar utveckling (Natural and cultural heritage as a resource for sustainable development) proposes that:

- national cross-sector government mandates are developed to increase the collaboration between operators within natural and cultural heritage and operators within development and growth

- natural and cultural heritage authorities create meeting places for developing a dialogue with national, regional and local operators working with development and growth issues

- models are investigated for how central government, municipalities and commercial operators can finance the preservation of natural and cultural heritage as a foundation and infrastructure for business

- natural and cultural heritage authorities initiate more collaboration between public, private, civil and academic operators in the form of e.g. partnerships.

Nordic follow-up projects proposed by the project relate to:

- exchange of experiences and analysis of best practice between Nordic landscapes (regions/local communities) who use natural and cultural heritage purposefully for development and growth

- collaboration on principles for sustainable tourism

- analysis and testing of methods for economic evaluation of natural and cultural environments

\section{Background}

The project Natural and cultural heritage as a resource for sustain-able development started in the summer of 2008 with financing from the Nordic Council of Ministers. It is based on collaboration between natural and cultural heritage authorities and all Nordic countries are represented, including the Faeroes. The project started with a mapping of how the different countries work with natural and cultural heritage as factors for development and growth (TemaNord 2009:514). During the next phase of the project, three thematic conferences were held focusing on A good living environment, Business development and Natural and cultural heritage 
tourism. As part of the final phase, a workshop, Natural and cultural heritage power 2010, was held, which referred back to the results from the conferences and discussed possible action plans. The project has focused on the added values that natural and cultural heritage can contribute to sustainable development and growth. The goal for the project has been to:

- Make natural and cultural heritage visible as factors for development and growth

- Strengthen the collaboration between the policy areas and operators involved at national and Nordic level

- Show how natural and cultural heritage can be integrated into development and growth processes

- Provide proposals for measures and continued work

\section{Central conclusions and proposals in summary}

\section{Natural and cultural heritage can contribute to development and growth...}

Natural and cultural heritage are development resources, in both tangible and intangible terms. They are sources of knowledge that provide experiences, awaken curiosity and lend a perspective. These are important foundations for new ways of thinking, innovation and further development. Natural and cultural heritage are an expression for what the places have been, what they are and what they can become. By studying and disseminating natural and cultural heritage, the resources and prerequisites of the place become visible, both from a historical and a development perspective.

It is only when natural and cultural heritage values become visible that they can be used strategically for the purpose of creating value. There is a link between ecological, social, cultural and financial value creation. A prerequisite for sustainable development is therefore that nature, cultural heritage and other interests are regarded as each other's resources.

\section{... and the use of natural and cultural heritage values shall be sustainable}

Those who use the natural and cultural heritage need to ensure sustainable management at the same time as representatives of natural and cultural heritage need to look to the needs of users. In negotiations between different interests, we need to look for solutions based on both general knowledge about sustainability and location-specific prerequisites. The important thing is to have insight into the context and to think and act on the basis of both a local and global perspective. 


\section{Natural and cultural heritage authorities have an important role to play together...}

It is often factors other than natural and cultural heritage that are considered as important for regional and local development and growth. It is crucial that natural and cultural heritage is included with other interests at national, regional and local level. It is important that differing perspectives are contrasted and weighed up against each other, at the same time as an exchange of experience and learning occurs that may drive the development forward. In other words, in order for natural and cultural heritage to be a force for sustainable development and growth, interplay between the operators affected is needed, as is interaction between the strategic and the practical levels.

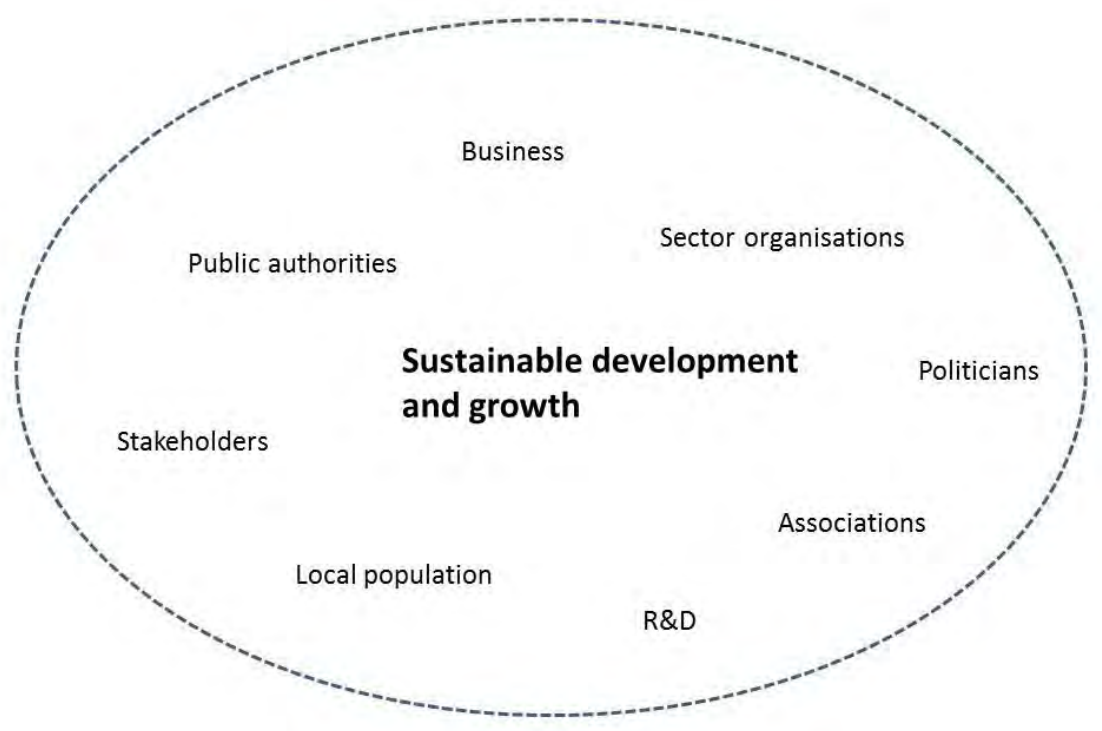

The cooperation arena for natural and cultural heritage in sustainable development and growth consist of a large number of different operators at differing levels in society and both within the public and the private spheres. The collaborating con-stellation varies depending on the issue and its geographic location and relevance.

Meeting placed for cross-sector collaboration should be arranged at all levels in society. In order to achieve collaboration across sector borders, it is often not enough to show good will; instead clear motives are often needed. The gains from collaboration need to be identified within the operational areas affected. It is also important for the collaboration to be linked to some form of obligation. The central political level should therefore give joint mandates to authorities at national and regional level in order to develop the work with natural and cultural heritage as value-creating social resources. It is also important that long-term collaboration between different parties is formalised, such as through cooperation agreements, partnerships, joint action plans or jointly financed programmes running for long periods of time. 
Create a framework that supports regional and local initiatives...

A central government framework that facilitates and can act as a catalyst for local initiatives requires better coordinated sector interests in terms of goals, control instruments and measures and a clear division of responsibilities between the operators. For this purpose, there may be a need for central government to identify and analyse factors that variously facilitate and hinder cross-sector coordination. Central government initiatives can be an importance driving force for starting new projects and operations at regional and local level. Such initiatives should be followed up in order to safeguard skills development and dissemination of experiences.

\section{... and develop a dialogue as a working method}

In order to safeguard commitment and knowledge in the local community, central government increasingly needs to be a partner in the dialogue and a fellow actor in regional and municipal development processes. Central government agencies need skills and tools for linking together actors and functioning as a bridge between the overall strategic level and the local practical level.

\section{Integrate natural and cultural heritage in municipal development work...}

Many municipalities are starting projects in order to place natural and cultural heritage on the political agenda and to include these issues in a more comprehensive way in development work and planning processes. In this conjunction, central government agencies should monitor, analyse and disseminate knowledge about municipal, inter-municipal and regional development work.

Many municipalities are starting projects in order to place natural and cultural heritage on the political agenda and to include these issues in a more comprehensive way in development work and planning processes. In this conjunction, central government agencies should monitor, analyse and disseminate knowledge about municipal, inter-municipal and regional development work.

There are good examples of how natural and cultural heritage is used strategically as a driving force in the renewal of towns and areas. Natural and cultural heritage is closely linked to the local identity and can contribute to places being experienced as more interesting and attractive, and thereby give rise to development in the form of immigration, job opportunities and improved quality of life, for example.

\section{... and involve the citizens}

Municipalities have an important role to play in holding together the local democracy arena. It is imperative that the local population participate in the development of their surroundings and that their knowledge and experiences are safeguarded, at the same time as it is important to 
underline the importance of the work of professionals in the development work. Experience shows that projects based on citizen participation are more robust and successful over time.

\section{Create the prerequisites for sustainable business development...}

Natural and cultural environment, but also natural and cultural heritage information, can be regarded as infrastructure for economic development. Central government and municipalities, in their capacity as authorities and property owners, are important actors for making natural and cultural heritage accessible. Protected environments are often particularly attractive from a business perspective. In many cases, through developed strategies, plans and regulations, it is possible to create prerequisites for sustainable operations and increased employment in and in conjunction with these areas. At the same time, this also increases the demands on those operators that use the resource to return income to the local community and the environments being used by the general public. Models for financing collective goods, such as in the form of care and maintenance of natural and cultural heritage, need to be investigated.

National natural and cultural heritage authorities should carry out measures together with authorities and sector organisation in business life to develop competence about the importance of natural and cultural values for sustainable business development. Good examples that may give rise to inspiration and learning for operations based on natural and cultural heritage should be disseminated. Innovative environments across sector, country and county borders should be stimulated.

\section{... in cooperation with private and public interests}

Demand governs the market. This means that expert perspectives, which have often been governing in terms of the management of natural and cultural heritage, need to be supplemented with a user and customerorientated way of working. At the same time, there is a need to strengthen the mechanisms that mean the market can support sustainable development.

Binding agreements and partnerships between business, public authorities, research environments and the voluntary sector can give mutual benefit between the actors. The natural and cultural heritage authorities together with other public authorities should consider engaging in such partnerships for the purpose of developing housing environments, destinations and business enterprises.

Commercial enterprises often require relatively quick returns on their investments, while public actors have the opportunity to act in a longer time perspective. At the same time, it is a prerequisite that profitmaking operations must be profitable in order to be sustainable in the long term. Central success factors for achieving this are, for example, good market understanding, a working interplay with the local community and sustainable use of the natural and cultural heritage. Also, cen- 
tral government initiatives should have a longer time-frame than is currently usual in order to achieve the desired results. Public authorities should strive for improvements to regulations that reduce the administrative burden for companies that carry out operations based on natural and cultural heritage.

\section{Create good policies for sustainable tourism...}

Good strategies, principles and quality assurance systems for sustainable tourism are of great importance for how the tourism business will develop. The Nordic countries can learn from each other in terms of clarifying what sustainable tourism means in practice. The tourism, natural and cultural heritage authorities should collaborate on concrete projects and in this way develop their cooperation. There is a need for a certification system for both destination and operations that safeguards the interplay between environment, economy and society. Properly designed, certification can be a tool for integrating tourism in sustainable social development.

\section{... and unite destination and local community development}

Destination development needs to go hand in hand with sustainable development of local communities. A crucial condition for this is that tourism is based on the prerequisites of the locality. Another experience is that investment in large/strong tourism companies also can favour small-scale operations at the destination. In order to make sure the natural and cultural heritage is a permanent and reinforcing factor for tourism development, it is crucial that the values are considered both as a resource and a product.

Sustainable tourism can provide a competitive advantage in the fight for customers compared with other destinations. But this requires skills. The tourism sector needs to understand what is needed and act so that natural and cultural heritage values can be developed as long-term resources for the industry. On the other hand, the natural and cultural heritage authorities need to develop their understanding of the industry's requirements for market adaptation and profitability. The distances between sector authorities, business and the local community need to be shortened in order to achieve effective cooperation with good results.

In order to enable delivery of interesting and in-depth experiences to visitors, information, guidance and not least good hosting are becoming ever more important. In order to meet this increased need, methods and formats for training and guiding about the local natural and cultural heritage should be reviewed and developed.

\section{Communicate natural and cultural heritage}

The importance of designing dissemination and communication strategies for increasing knowledge about natural and cultural heritage should not be underestimated. Better adaptation and coordination of the digital services and websites of public authorities can contribute to more cohe- 
sive, systematic and target group adapted information and marketing of natural and cultural heritage.

Technical development creates new opportunities for communication. Not least, there is a potential for reaching individual travellers via the Internet, mobile telephones and other channels. There are also several examples of digital interactive tools for activating the local population's knowledge about their everyday landscape and to share locationspecific stories and memories.

\section{Research, analyse and monitor developments}

There is a need for interdisciplinary research linked to natural and cultural heritage as a resource for sustainable development and growth. This concerns more in-depth knowledge in the interface between nature, cultural heritage and business among other areas. Nordic national authorities together with the scientific sphere should take initiatives for a strategic summary of the research that has been carried out, what results it has produced and the needs that exist.

It is important to capture trends, status and effects from all sustainability dimensions. All values cannot be evaluated in financial terms, but are still of economic importance in both the short and the long run. Indexes that also capture qualitative values therefore continue to require development and be upgraded in importance.

\section{Proposals for continued Nordic cooperation}

This project has the following proposals for continued Nordic project cooperation:

- Exchange of experiences and analysis of methods and collaboration models implemented between Nordic landscapes (regions/local communities) that work with natural and cultural heritage as a resource for development and growth with an eye to the future. This is about giving selected areas a Nordic arena for discussing important social issues relating to natural and cultural heritage as future resources, and for analysing "best practice" for coordinated central government involvement in social development processes

- Projects aimed at working out recommendations for joint Nordic principles for sustainable tourism

- Review research and methods for financial evaluation of natural and cultural environments and as a next step test comparable methods in the Nordic countries 



\section{Yhteenveto}

Pohjoismainen projekti Luonto ja kulttuuriperintö kestävän kehityksen voimavarana ehdottaa, että:

- muodostetaan kansallisia, monialaisia hallituksen toimeksiantoja vahvistamaan yhteistoimintaa luonto- ja kulttuuriperintötoimijoiden ja kehitys- ja kasvutoimijoiden välillä.

- luonto- ja kulttuuriperintöviranomaiset luovat kohtauspaikkoja kansallisten, alueellisten ja paikallisten kehitys- ja kasvukysymysten parissa työskentelevien toimijoiden välisen vuoropuhelun kehittämiseksi.

- selvitetään malleja, miten valtio, kunnat ja kaupalliset toimijat voivat rahoittaa luonnon ja kulttuuriperinnön säilyttämistä elinkeinoelämän perustaksi ja välineistöksi.

- luonto- ja kulttuuriperintöviranomaiset panevat alulle useita yhteistyöhankkeita julkisten, yksityisten, siviilihenkilöiden ja akateemisten toimijoiden kanssa esimerkiksi kumppanuuden muodossa.

Pohjoismainen seurantaprojekti, jota projekti ehdottaa, käsittelee:

- pohjoismaisten maakuntien (seutujen/paikallisyhteisöjen) parhaiden käytäntöjen kokemusten vaihtoa ja analyysiä, joka ottaa luonnon ja kulttuuriperinnön määrätietoisesti kehityksen ja kasvun käyttöön

- kestävän matkailun perusteita koskevaa yhteistyötä

- luonto- ja kulttuurimiljöiden taloudellisessa arvioinnissa käytettävien menetelmien analyysiä ja testausta.

\section{Taustaa}

Projekti Luonto ja kulttuuriperintö kestävän kehityksen ja kasvun voimavarana (Natur och kulturarv som resurs för hållbar utveckling) alkoi kesällä 2008 Pohjoismaisen ministerineuvoston rahoituksella. Se perustuu luonto- ja kulttuuriperintöviranomaisten yhteistoimintaan, ja kaikki Pohjoismaat Färsaaret mukaan lukien ovat edustettuina. Projekti alkoi kartoittamalla, kuinka eri maat työskentelevät koskien luontoa ja kulttuuriperintöä kehityksen ja kasvun tekijöinä (TemaNord 2009:513). Projektin seuraavassa vaiheessa järjestettiin kolme konferenssia, joiden teemoina olivat Hyvä elinympäristö (God livsmiljö), Elinkeinokehitys (Näringsut-veckling) ja Luonto- ja kulttuuriperintömatkailu (Natur- och 
kulturarvs-turism). Osana päättävää vaihetta toteutettiin Luonto- ja kulttuuriperintö voimavarana 2010 -workshop (Natur- och kulturarvskraft 2010), joka yhdisti konferenssien tulokset ja ne lähtökohtanaan keskusteli mahdollisista jatkotoimenpiteistä. Projekti on kohdennettu lisäarvoihin, joita luonto ja kulttuuriperintö voivat tuoda kestävään kehitykseen ja kasvuun. Projektin päämääränä on ollut, että:

- Tuodaan luonto ja kulttuuriperintö näkyviksi kehityksen ja kasvun tekijöinä.

- Voimistetaan yhteistoimintaa kyseisten politiikan osa-alueiden ja alan kansallisten ja pohjoismaisten toimijoiden välillä.

- Osoitetaan, kuinka luonto ja kulttuuriperintö voidaan integroida kehitys- ja kasvuprosesseihin.

- Tehdään aloitteita toimenpiteiksi ja työn jatkamiseksi.

\section{Alla yhteenveto keskeisistä päätelmistä ja ehdotuksista}

\section{Luonto ja kulttuuriperintö voi myötävaikuttaa kehitykseen ja kasvuun...}

Luonto ja kulttuuriperintö ovat kehityksen voimavaroja sekä aineellisesti että aineettomasti. Ne ovat tiedon lähteitä, jotka antavat elämyksiä, laajentavat näkökulmaa ja herättävät uteliaisuutta. Tämä on tärkeä perusta uudelle ajattelutavalle, innovaatioille ja jatkokehitykselle. Luonto ja kulttuuriperintö ovat ilmaisu sille, mitä paikat ovat olleet, mitä ne ovat ja miksi ne voivat tulla. Tutkimuksen sekä luonnon ja kulttuuriperinnön välittämisen kautta paikan resurssit ja edellytykset tulevat näkyviksi sekä historiallisesta että kehitysnäkökulmasta katsoen.

Vasta kun luonto- ja kulttuuriperintöarvot on tehty näkyviksi, niitä voidaan käyttää strategisesti lisäarvoa tuottavassa tarkoituksessa. Ekologisen, sosiaalisen, kulttuurisen ja taloudellisen lisäarvon tuottamisella on yhteys toisiinsa. Sen tähden yksi kestävän kehityksen edellytys on, että luonto, kulttuuriperintö ja muut intressit nähdään toistensa voimavaroina.

... ja luonto- ja kultturiperintöarvojen käytön tulee olla kestävää Luonnon ja kulttuuriperinnön käyttäjän on pidettävä huoli kestävästä hoidosta samanaikaisesti kuin luonto- ja kulttuuriperinnön edustajien tulee nähdä käyttäjien tarpeet. Eri intressien välisissä neuvotteluissa on etsittävä ratkaisuja, jotka perustuvat sekä yleiseen kestävää kehitystä käsittelevään tietoon kuin paikan erityisedellytyksiin. On oltava näkemystä asiayhteyksistä ja ajateltava ja toimittava sekä paikallisesti että globaalisti. 
Luonto- ja kulttuuriperintöviranomaisilla on tärkeä yhteinen rooli... Luonto- ja kulttuuriperintöviranomaisten välinen yhteistyö antaa paremmat edellytykset ajaa asioita, jotka koskevat parempaa elämänlaatua ja kestävää kehitystä. Jos viranomaiset esiintyvät ulospäin yhtenä osapuo-lena, se voi myötävaikuttaa selkeyden lisääntymiseen ja siihen, että sanoma saa lisää painoarvoa. Viranomaiset voivat myös antaa parempaa palvelua kaikille muille toimijoille, esimerkiksi tarjoamalla yhteistä tietoa ja informaatiota.

\section{... ja niiden täytyy toimia yhdessä muiden intressien kanssa}

Usein muita tekijöitä kuin luontoa ja kulttuuriperintöä pidetään tärkeinä, kun on kysymys seudullisesta ja paikallisesta kehityksestä ja kasvusta. Ratkaisevaa on, että luonto ja kulttuuriperintö otetaan muiden intressien ohelle kansallisella, seudullisella ja paikallisella tasolla. On tärkeää, että eri näkökulmia punnitaan toisiaan vasten samanaikaisesti kun tapahtuu kokemusten vaihtoa ja oppimista, jotka voivat viedä kehitystä eteenpäin. Jotta luonto ja kulttuuriperintö voivat olla kestävän kehityksen ja kasvun voima, vaaditaan toisin sanoen asianosaisten toimijoiden välistä yhteispeliä ja strategisen ja käytännön tason vuorovaikutusta.

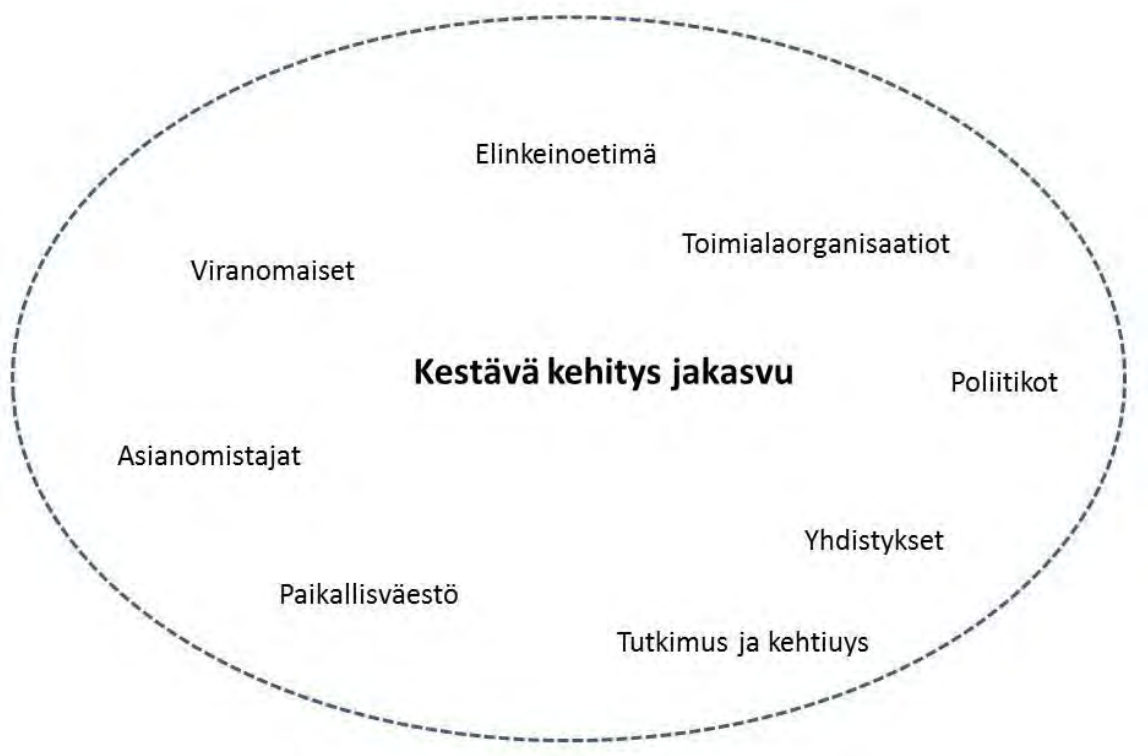

Yhteistoiminta-areena alueella luonto ja kulttuuriperintö kestävässä kehityksessä ja kasvussa käsittää monia eri toimijoita eri yhteiskuntatasoilla ja sekä julkisella että yksityisellä sektorilla. Yhteistoiminta-areenan kokoonpano vaihtelee riippuen kysymyksestä, sen maantieteellisestä sijainnista ja relevanssista.

Kohtaamispaikkoja eri sektorit ylittävälle yhteistoiminnalle pitää järjestää kaikilla yhteiskunnan tasoilla. Yhteistyön aikaansaamiseen yli sektorirajojen ei usein riitä hyvä tahto, vaan tarvitaan usein selkeitä motiiveja. Yhteistoiminnasta saatavat hyödyt on tunnistettava kyseisillä toimintaalueilla. On myös tärkeää, että yhteistyö on sidottu jonkinlaiseen velvoit- 
teeseen. Keskeisen poliittisen tason tulee sen tähden antaa yhteisiä toimeksiantoja viranomaisille valtakunnallisella ja seudullisella tasolla kehittääkseen luontoa ja kulttuuriperintöä koskevaa työtä lisäarvoa tuottavina yhteiskunnan voimavaroiksi. On myös merkittävää, että eri osapuolien pitkäjänteinen yhteistoiminta vakiinnutetaan yhteistyösopimuksin, kumppanuuksin, yhteisin toimintasuunnitelmin tai yhdessä rahoitetuin ohjelmin, jotka kattavat pidempiä aikavälejä.

\section{Luodaan kehys joka tukee seudullisia ja paikallisia aloitteita...}

Valtiollisen kehys, joka helpottaa ja voi toimia paikallisten panostusten ja aloitteiden katalysaattorina, vaatii eri sektoreiden paremmin yhdensuuntaistettuja intressejä koskien tavoitteita, ohjausmenetelmiä ja toimenpiteitä sekä selkeää ja selvää vastuuunjakoa toimijoiden välillä. Tässä tarkoituksessa voi olla tarpeen, että valtio tunnistaa ja analysoi tekijöitä, jotka helpottavat tai vastaavasti vaikeuttavat monialaista koordinointia. Valtiolliset aloitteet voivat olla tärkeä vetovoima uusien projektien ja toimintojen käynnistämiseksi seudullisella ja paikallisella tasolla. Näitä aloitteita on seurattava, jotta voidaan varmistaa osaamisen kehittäminen ja kokemusten jakaminen.

\section{... ja kehitetään vuoropuhelua työmenetelmänä}

Paikallisyhteisössä olevan kiinnostuksen ja tiedon hyödyntämiseksi valtion on lisääntyvässä määrin osallistuttava vuoropuheluun ja oltava yhtenä toimijana seudullisissa ja kunnallisissa kehitysprosesseissa. Valtion hallintoelimet tarvitsevat pätevyyttä ja työkaluja toimijoiden yhteen linkittämiseen ja toimiakseen siltana strategisen tason ja paikallisen käytännön tason välillä.

\section{Integroidaan luonto ja kulttuuriperintö kunnalliseen kehitystyöhön...}

Monet kunnat aloittavat projekteja luonnon ja kulttuuriperinnön tuomiseksi poliittiseen päiväjärjestykseen ja liittääkseen kysymykset syvällisemmin kehitystyöhön ja suunnitteluprosesseihin. Keskeisten laitosten pitää tässä yhteydessä seurata, analysoida ja levittää tietoa kunnallisesta, kuntien välisestä ja seudullisesta kehitystyöstä.

Yhteistoiminta eri sektoreiden hallintojen, kultturiperintö- ja luonnonsuojelupätevyydet mukaan lukien, on ratkaisevaa, jotta kysymyksiin saadaan kokonaisnäkemys. Käyttämällä luontoa ja kulttuuriperintöä tärkeinä yhteiskunnan voimavaroina luodaan tietoisuutta näistä arvoista ja suhtautumistapaa näihin ja niiden merkitykseen elämänlaadulle ja paikalliselle kehitykselle. Taajamien lähellä sijaitsevien luonto- ja kultturimiljöiden arvoa ei tule vähätellä. Ne ovat keskeisiä alueita virkistyksen ja ulkoilun ja siten ihmisten terveyden kannalta. Pienetkin viheralueet voivat olla arvokkaita paikkoja lapsille ja koulutoiminnalle.

Siitä, kuinka luontoa ja kultturiperintöä on käytetty strategisesti käyttövoimana kaupunki- tai alueuudistuksessa, on hyviä esimerkkejä. 
Luonto ja kulttuuriperintö liittyvät läheisesti paikalliseen identiteettiin ja ne voivat myötävaikuttaa siihen, että paikkoja pidetään kiinnostavampina ja houkuttelevampina ja siten käynnistää kehityksen esimerkiksi paikkakunnalle muuttavien, uusien asukkaiden, työtilaisuuksien ja paremman elämänlaadun muodossa.

\section{... ja saadaan kansalaiset mukaan}

Kunnilla on tärkeä rooli paikallisten toimijoiden koolle kutsujana. On erittäin tärkeää, että paikallisväestö osallistuu ympäristönsä kehitykseen ja että heidän tietojansa ja kokemuksiansa käytetään hyväksi, samalla kun on tärkeää painottaa ammattimaista osaamista kehitystyössä. Kokemus osoittaa, että projekteista, jotka perustuvat kansalaisten osallistumiseen, tulee ajan mittaan menestyksellisempiä.

\section{Luodaan edellytykset kestävälle elinkeinojen kehittämiselle...}

Luonto- ja kulttuuriympäristöjä, mutta myös luonto- ja kulttuuriperintötietoa, voidaan pitää välineistönä taloudelliselle kehitykselle. Valtio ja kunnat ovat viranomaisten ja kiinteistönomistajien ominaisuudessa tärkeitä toimijoita luonnon ja kulttuuriperinnön saatavuuden varmistamisessa. Elinkeinoelämän perspektiivistä katsoen erityisen houkuttelevia ovat usein suojellut miljööt. Monissa tapauksissa on mahdollista monimutkaisin strategioin, suunnitelmin ja määräyksin luoda edellytyksiä kestäviin toimintatapoihin ja työllisyyden lisäämiseen näillä ja näihin liittyvillä alueilla. Tämä kasvattaa samalla myös voimavaraa käyttäville toimijoille asetettuja vaatimuksia tuoda tuloja paikallisyhteisölle ja miljöille, jotka ovat yleisessä käytössä. Kollektiivisten hyötyjen rahoitusmalleja, esimerkiksi luonnon ja kulttuuriperinnön hoidon ja ylläpidon muodossa, pitää selvittää.

Kansallisten luonto- ja kulttuuriperintöviranomaisten pitää yhdessä viranomaisten ja elinkeinoelämän toimialaorganisaatioiden kanssa ryhtyä toimenpiteisiin osaamisen kehittämiseksi aluella, joka käsittelee luonto- ja kulttuuriarvojen merkitystä kestävälle elinkeinokehitykselle. Hyviä esimerkkejä luonnon- ja kulttuuriperinnön pohjalta tehdyistä hankkeista, jotka voivat inspiroida ja olla opettavaisia, tulee levittää. Innovatiivisia miljöitä yli eri sektoreiden, maan- ja lääninrajojen tulee innostaa.

\section{... yksityisen ja julkisen vuorovaikutuksella}

Kysyntä ohjaa markkinoita. Se merkitsee sitä, että asiantuntijaperspektiiviä, joka on usein ollut vallitsevana, kun kyseessä on luonnon ja kulttuuriperinnön vaaliminen, pitää täydentää käyttäjä- ja asiakassuuntautuneella työtavalla. Samalla on tarpeen vahvistaa mekanismeja, joiden ansiosta markkinat voivat tukea kestävää kehitystä.

Velvoittavat sopimukset ja kumppanuudet sekä elinkeinoelämän, viranomaisten, tutkimusympäristöjen ja vapaaehtoisen sektorin välillä voivat lisätä toimijoiden keskinäistä ajatusten ja kokemusten vaihtoa. 
Luonto- ja kulttuuriperintöviranomaisten pitää yhdessä muiden viranomaisten kanssa harkita liittymistä osalliseksi sellaisiin kumppanuuksiin, joiden tarkoituksena on kehittää asuinympäristöjä, kohteita ja elinkeinoelämää.

Kaupallinen toiminta vaatii usein suhteellisen nopeaa tuottoa investoinneilleen, kun taas julkiset toimijat voivat toimia pidemmällä aikaperspektiivillä. Samanaikaisesti oletuksena on, että voittoa tavoittelevien yhtiöiden on oltava kannattavia ollakseen kestäviä pitkällä aikavälillä. Keskeiset menestystekijät sen saavuttamiseksi ovat esimerkiksi hyvä markkinatuntemus, toimiva yhteistyö paikallisyhteisön kanssa ja luonnon ja kulttuuriperinnön kestävä käyttö. Valtiollisilla aloitteilla pitää sen lisäksi olla pidempi aikakehys kuin mitä nykyisin on tavallista, jotta voidaan saada haluttuja tuloksia. Viranomaisten pitää pyrkiä sääntöparannuksiin, jotka pienentävät luonto- ja kulttuuriperinnön pohjalta toimivien yritysten hallinnollista kuormaa.

\section{Luomaan hyvää politiikkaa kestävälle matkailulle...}

Kestävän matkailun hyvillä strategioilla, periaatteilla ja laadunvarmistusjärjestelmillä on suuri merkitys sille, miten matkailuelinkeino kehittyy. Pohjoismaat voivat oppia toisiltaan, kuinka tuodaan julki, mitä on selvennettävä, mitä kestävä matkailu tarkoittaa käytännössä. Matkailu-, luonto- ja kulttuuriperintöviranomaisten on yhdistyttävä konkreettisissa projek-teissa, jotta ne voivat siten kehittää keskinäistä yhteistyötään. Sekä kohteille että toiminnalle tarvitaan sertifiointijärjestelmä, joka valvoo miljöön, talouden ja yhteiskunnan vuorovaikutusta. Oikein laadittuna serti-fiointi voi olla väline matkailun integroimiseksi osaksi kestävää yhteiskuntakehitystä.

\section{... ja yhdistämään kohde- ja paikallinen yhteiskuntakehitys}

Kohdekehityksen tulee tapahtua käsi kädessä paikallisyhdyskunnan kestävän kehityksen kanssa. Ratkaisevaa sille on, että lähtökohtana matkailulle ovat paikan edellytykset. Satsaukset suuriin/vahvoihin matkailuyrityksiin voivat myös hyödyttää pienen mittakaavan yrityksiä kohteessa. Sen varmistamiseksi, että luonto- ja kulttuuriperintö on pysyvä ja vahvistava tekijä matkailun kehityksessä on keskeistä, että arvoja pidetään sekä voimavarana että tuotteena.

Kestävä matkailu voi antaa kilpailuetuja kilpailussa asiakkaista muiden matkakohteiden kanssa. Tämä vaatii kuitenkin kompetenssia. Matkailuelinkeinon pitää ymmärtää, mitä tarvitaan ja toimia niin, että luonto- ja kulttuuriperintöarvoja voidaan kehittää elinkeinon pitkän tähtäyksen resursseina. Luonto- ja kulttuuriperintöviranomaisten pitää toisaalta kehittää ymmärrystään elinkeinon vaatimuksista, joka koskevat markkinasopeuttamista ja kannattavuutta. Sektorin viranomaisten, elinkeinon ja paikallisyhteisön välisiä etäisyyksiä on lyhennettävä, jotta yhteistoiminnasta tulee tehokasta ja tuloksellista. 
Jotta kävijöille voi tarjota kiinnostavia ja syventäviä elämyksiä, tulee tiedosta, opastuksesta, eikä vähiten hyvästä isännyydestä, yhä tärkeämpää. Tähän kasvavaan tarpeeseen vastaamista varten paikallista luontoa ja kulttuuriperintöä koskevan koulutuksen ja ohjauksen menetelmät ja muodot on selvitettävä ja niitä on kehitettävä.

\section{Viestimään luonnosta ja kulttuuriperinnöstä}

Viestintä- ja tiedotustrategoiden laatimisen tärkeyttä tiedon lisäämiseksi luonnosta ja kulttuuriperinnöstä ei pidä aliarvioida. Eri viranomaisten sähköisten palveluiden ja kotisivujen parempi sopeuttaminen ja koordinointi voi edesauttaa luonnon ja kulttuuriperinnön kootumpaa, systemaattisempaa ja paremmin kohderyhmää palvelevaa tietoa ja markkinointia.

Tekniikan kehittyminen luo uusia kommunikaatiomahdollisuuksia. Niistä vähäisin ei ole mahdollisuus tavoittaa yksittäisiä matkailijoita Internetin, matkapuhelimien ja muiden kanavien välityksellä. On myös monia esimerkkejä digitaalisista, interaktiivisista työkaluista, joilla voidaan aktivoida paikallisen väestön tietoja heidän arkimaisemastaan ja jakaa paikalle ominaisia kertomuksia ja muistoja.

\section{Tutkimaan, analysoimaan ja seuraamaan kehitystä}

On tarpeen tehdä luontoon ja kultuuriperintöön kestävän kehityksen ja kasvun voimavarana liittyvää poikkitieteellistä tutkimusta. Kysymys on muun muassa tietojen syventämisestä luonnon, kulttuuriperinnön ja elinkeinoelämän rajapinnalla. Kansallisten, pohjoismaisten viranomaisten pitää yhdessä tutkijamaailman kanssa tehdä aloite strategiseksi yhteenvedoksi siitä, mitä tutkimusta on tehty, mitä tuloksia tutkimuksesta on saatu ja mitä tarpeita on olemassa.

On tärkeää ottaa kiinni kaikkien kestävän kehityksen ulottuvuuksien trendeistä, arvoasemista ja vaikutuksista. Kaikkia arvoja ei voi arvottaa taloudellisin termein, mutta niillä on kuitenkin taloudellista merkitystä sekä lyhyellä että pitkällä tähtäyksellä. Indeksiä, joka ottaa huomioon myös laadulliset arvot, on sen tähden jatkuvasti kehitettävä ja sen merkitystä on nostettava.

\section{Ehdotus jatketuksi pohjoismaiseksi yhteistyöksi}

Projekti ehdottaa seuraavaa pohjoismaisen projektiyhteistyön jatkamiseksi:

- Kokemusten vaihtoa ja käytettyjen menetelmien ja yhteistyömallien analysointia niiden pohjoismaisten maakuntien (seutukuntien/ paikallisyhteisöjen) välillä, jotka työskentelevät tulevaisuuteen suuntautuvasti luonto ja kulttuuriperintö kehityksen ja kasvun voimavarana. Valituille alueille on annettava pohjoismainen areena, jolla ne voivat keskustella tärkeistä yhteiskuntakysymyksistä, jotka liittyvät luontoon ja kulttuuriperintöön tulevaisuuden resursseina 
sekä analysoitava parhaita käytäntöjä sitä varten, että valtio koordinoidusti osallistuu yhteiskuntakehityksen prosesseihin

- Projekteja, joiden tarkoituksena on laatia suosituksia kestävän matkailun yhteisistä pohjoismaisista periaatteista

- Käydään läpi luonto- ja kulttuurimiljöiden taloudellista arviointia koskevaa tutkimusta ja menetelmiä sekä seuraavassa vaiheesa testataan vastaavia menetelmiä Pohjoismaissa 


\section{Útdráttur}

Norræna verkefnið Nýting náttúru- og menningarminja við sjálfbæra nýsköpun og próun, leggur til að:

- mótuð séu á landsvísu pverfagleg verkefni, sem studd verða af ríkinu, til að̃ styrkja samvinnu milli peirra sem vinna annars vegar að málefnum náttúrunnar og menningararfsins og hins vegar við próun og nýsköpun

- bau yfirvöld sem sjá um málefni náttúru- og menningarminja í hverju landi hefji samræður við pá sem vinna að próunar og nýsköpunarmálum heima í héraði s.s. sveitarfélög og almenning

- gerð verði líkön um hvernig ríkið, sveitarfélög og pátttakendur í viðskiptalífinu geti útvegað fjármagn sem nota skal til að varðveita náttúru- og menningarminjar sem síðan geta orðið grunnur að nýjum störfum

- yfirvöld náttúru- og menningarminja setji af stað fleiri samvinnuverkefni milli opinberra aðila, einkaaðila og aðila úr háskólasamfélaginu með t.d. samstarfssamningum

Verkefnið leggur til að próuð verði eftirfarandi samnorræn verkefni:

- skipst á reynslusögum og greining á „bestu útfærslu“ milli norrænna landsvæða (sveitarfélaga, bæjarfélaga) sem nýta náttúru og menningararf markvisst til próunar og nýsköpunar

- samvinna um meginreglur fyrir sjálfbæra ferðabjónustu

- greining og prófun á aðferðum til að meta hagrænt gildi náttúru- og menningarminja

\section{Forsaga}

Verkefnið Nýting náttúru- og menningarminja við sjálfbæra nýsköpun og próun hófst sumarið 2008 með fjármögnun frá Norrænu ráðherranefndinni. Pað byggist á samvinnu milli peirra yfirvalda sem bera ábyrgð á náttúru- og menningarminjum á öllum Norðurlöndunum, par með talið Færeyjum. Verkefnið hófst með kortlagningu á hvernig hin ýmsu lönd nýta náttúru og menningararf sem pátt í próun og nýsköpun (TemaNord 
2009:513). Í öðrum áfanga verkefnisins voru haldnar prjár pemaráðstefnur sem beindu sjónum að pví hvernig náttúra og menningararfur hafa verið tengd saman og nýtt í peim tilgangi að auka lífsgæði manna, próa og efla atvinnulíf og vera uppspretta að nýjungum í ferðapjónustu. Lokaáfanginn var málstofa, Afl náttúru og menningararfs 2010, par sem kynntar voru niðurstöður af ráðstefnunum og út frá peim ræddar hugsanlegar leiðir til að hrinda peim í framkvæmd. Verkefnið hefur beinst að peim virðisauka sem náttúra og menningararfur geta lagt til sjálfbærrar próunar og nýsköpunar. Markmiðið með verkefninu hefur verið að:

- Draga fram náttúru- og menningarminjar sem pátt í próun og nýsköpun

- Styrkja samvinnu milli viðkomandi stjórnvalda og pátttakenda í hverju landi og á Norðurlöndunum

- Sýna hvernig náttúra og menningararfur geta fléttast inn í próunarog nýsköpunarferla

- Gera tillögu um aðgerðir og áframhaldandi vinnu

\section{Hér að neðan eru mikilvægar ályktanir og tillögur dregnar saman}

Náttúru- og menningarminjar geta stuðlað að próun og nýsköpun..

Náttúru- og menningarminjar er hægt að nýta í próun vöru, bæði efnislega og huglæga. Pau eru uppspretta pekkingar, vekja forvitni, veita upplifun og gefa ný sjónarhorn. Pekkingin leggur mikilvægan grunn fyrir nýjar hugmyndir, nýjungar og frampróun. Náttúra og menningararfur eru táknmynd pess sem viðkomandi staðir hafa verið, hvað peir eru og hvað peir geta orðið. Með pví að rannsaka hvað náttúran og menningararfurinn hafa veitt og miðla pekkingunni áfram verða sögulegar forsendur staðanna ljósari svo og möguleikar peirra til próunar.

Раð er ekki fyrr en verðmæti náttúru- og menningarminja eru gerð sýnileg, sem hægt er að nýta pau í virðisaukandi tilgangi. Samband er á milli vistfræðilegrar, samfélagslegrar, menningarlegrar og hagfræðilegrar virðisaukningar. Forsenda sjálfbærrar próunar er pess vegna að náttúru- og menningarminjum sé gert jafn hátt undir höfði og öðrum hagsmunum.

\section{... og nýting peirra verðmæta skal vera sjálfbær}

peir sem nýta náttúru og menningararf purfa að umgangast auðlindina á sjálfbæran hátt en jafnframt parf að líta til parfa notendanna. Í málamiðlunum milli ýmissa hagsmuna parf að leita lausna sem grundvallast jafnt á pekkingu um sjálfbærni sem staðbundnum forsendum. Nauðsynlegt er að geta séð samhengi hlutanna og hugsa og framkvæma í samræmi við bæði staðbundin og hnattræn viðmið. 


\section{Yfirvöld sem sjá um náttúru- og menningarminjar gegna saman mikilvægu hlutverki...}

Meiri samvinna milli peirra yfirvalda sem hafa með náttúruminjar annars vegar og menningararfinn hins vegar að gera, getur haft hvetjandi áhrif á umræðu um aukin lífsgæði og sjálfbæra próun. Ef yfirvöld eru samstíga út á við verður boðskapur peirra skýrari og kröftugri. Yfirvöld geta líka veitt öðrum aðilum betri pjónustu, t.d. mætti hafa einn sameiginlegan gagnabanka um náttúru- og menningarminjar par sem hægt er að afla sér upplýsinga og pekkingar.

\section{... og pau verða að taka mið af öðrum hagsmunum}

Oft eru aðrir pættir en náttúra og menningararfur álitnir mikilvægari varðandi svæðisbundna og staðbundna próun og nýsköpun. Pað er lykilatriði að málefni náttúru og menningararfs séu metin til jafns á við aðra hagsmuni, bæði á landsvísu og heima í héraði. Pað er mikilvægt að hin ýmsu sjónarmið séu vegin og metin, jafnframt pví að skipst sé á reynslu og lærdómi sem leitt getur próunina áfram. Til pess að náttúru- og menningarminjar geti verið afl sem knýr áfram sjálfbæra próun og nýsköpun, krefst pað með öðrum orðum samspils milli peirra sem málið varðar og víxlverkunar milli peirra sem móta stefnuna og hinna sem nýta hana.

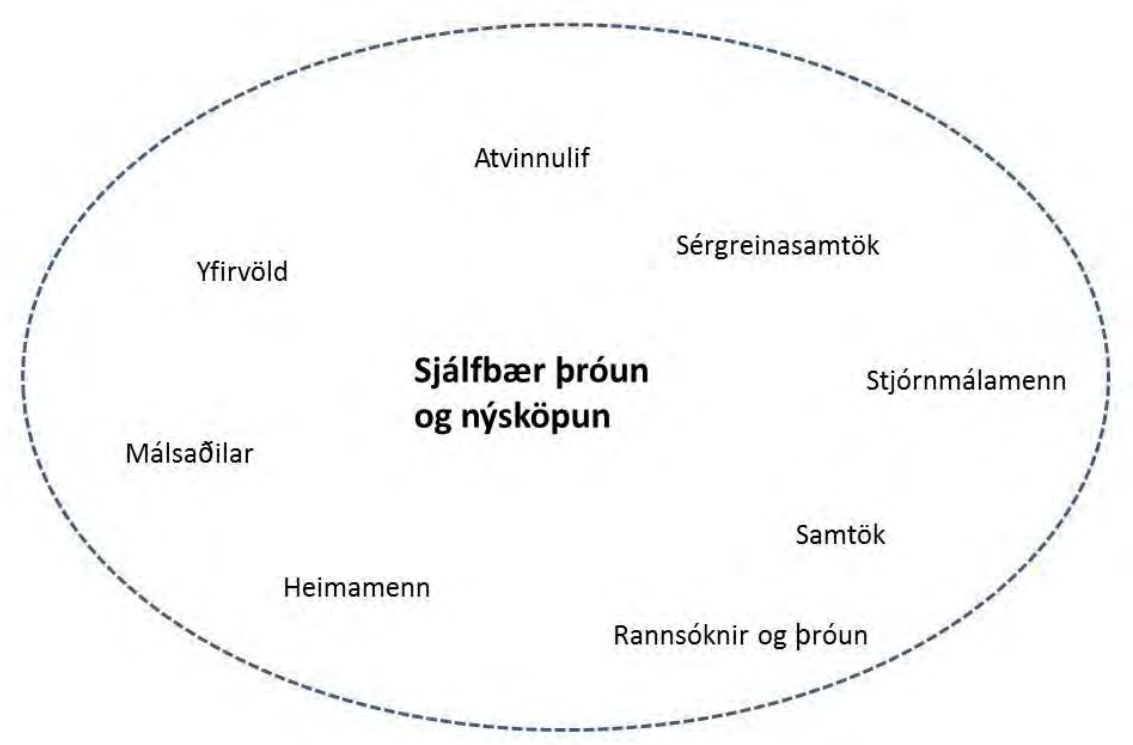

Samstarfssvið fyrir náttúru- og menningarminjar í sjálfbærri bróun og nýsköpun, er myndað af fjölda ólíkra aðila á ýmsum samfélagsstigum og jafnt innan hins opinbera sem einkageirans. Samverkandi pættir eru breytilegir eftir málum, stöðu peirra og mikilvægi.

Koma parf á vettvangi fyrir samvinnu í málefnum náttúruminja og menningararfs á öllum stigum stjórnkerfisins. Til pess að koma á slíkri samvinnu nægir sjaldan góður vilji einn og sér heldur parf markmiðið að vera skýrt. Ávinningur af samvinnunni parf að vera greinanlegur innan viðkomandi starfssviða. Pað er líka mikilvægt að samvinnan sé skuld- 
bindandi á einhvern hátt. Stjórnvöld ættu pess vegna að fela opinberum stofnunum og sveitarfélögum að próa sameiginlegar hugmyndir um hvernig auka má virði náttúru- og menningarminja fyrir samfélagið. Pað er einnig pýðingarmikið að samvinna til framtíðar mótist milli ólíkra aðila, t.d. í gegnum samstarfssamning og sameiginlegar framkvæmda- og fjárhagsáætlanir sem ná yfir löng tímabil.

\section{Myndið ramma sem styður svæðisbundið og staðbundið frumkvæði...}

Til pess að mynda opinberan ramma sem léttir undir og getur virkað sem hvati á staðbundnar fjárfestingar og frumkvæði, parf að horfa á sameiginlega hagsmuni greinanna varðandi markmið, stjórntæki og ráðstafanir auk pess sem nauðsynlegt er að skýrt og greinilegt sé hver beri ábyrgð á hverju. Í pessu augnamiði kann að vera pörf á að ríkið dragi fram og greini pætti sem auðvelda eða torvelda pverfaglega samhæfingu, eftir pví sem við á. Frumkvæði ríkisins getur verið mikilvægur aflgjafi til að gangsetja ný verkefni og starfsemi í héraði. Slíku frumkvæði ber að fylgja eftir til að hægt sé að tryggja samkeppnishæfni og deila reynslu með öðrum.

\section{... og próið samtal sem vinnuaðferð}

Til að varðveita áhuga og pekkingu í heimamanna parf ríkið í auknum mæli að vera samræðufélagi og pátttakandi í próunarferli svæða og sveitarfélaga. Stjórnsýsla ríkisins parf að búa yfir pekkingu og verkfæri til að tengja saman aðila og virka sem brú milli hins stefnumótandi yfirvalds og notandans.

\section{Sampættið náttúru- og menningarminjar í próunarstarfi sveitarstjórna...}

Margar sveitarstjórnir á Norðurlöndum hefja verkefni í peim tilgangi að koma náttúru- og menningarminjum á dagskrá stjórnmálanna og fella pau mál betur inn í próunarstarf og áætlanaferli sveitarfélaganna. Opinberar stofnanir ættu í framhaldi af pví að fylgja eftir, greina og dreifa pekkingu á próunarstarfi hjá sveitarfélögum, á milli sveitarfélaga og milli landshluta.

Samstarf milli opinberra stofnana, að meðtöldum yfirvöldum menningararfs og náttúruminja, er grundvallaratriði til að fá heildarsýn á málin. Með pví að benda á að náttúra og menningararfur séu mikilvæg auðlind fyrir samfélagið eflist vitund fólks um pau sem verðmæti og um mikilvægi peirra til að auka lífsgæði og staðbundna nýsköpun. Ekki hvað síst er mikilvægt að líta á verðmæti náttúru- og menningarumhverfis nálægt péttbýli. Pau eru lykilatriði fyrir tómstundir og útiveru og par með fyrir heilsu fólks. Jafnvel lítil græn svæði geta verið verðmætir staðir fyrir börn og skólastarfsemi.

Til eru góð dæmi um hvernig náttúra og menningararfur eru nýtt sem drifkraftur í borgar- eða svæðisendurnýjun. Náttúra og menningararfur 
eru nátengd sjálfsmynd hvers staðar og geta stuðlað að pví að hann verði álitinn áhugaverðari og meira aðlaðandi en ella. Pannig getur hann laðað til sín nýja íbúa, boðið upp á fjölbreyttari störf og bætt lífsgæði.

\section{... og virkið samborgarana}

Sveitarfélögin gegna hér mikilvægu hlutverki við að viðhalda lýðræði á hverjum stað. pað er grundvallaratriði að heimamenn taki pátt í að próa umhverfi sitt og að pekkingu peirra og reynslu sé haldið til haga, jafnframt pví að mikilvægt er að leggja áherslu á faglegt viðhorf í próunarstarfinu. Reynslan sýnir að verkefni sem byggja á pátttöku samborgaranna verða sterkari og njóta velgengni lengur.

\section{Skapið forsendur fyrir sjálfbærri próun atvinnulífs...}

Líta má á náttúru- og menningarumhverfi svo og upplýsingar um náttúruminjar og menningararf sem innviði fyrir efnahagslega próun. Stjórn og eignarréttur liggur hjá ríki og sveitarfélögum og pau gegna mikilvægu hlutverki í að gera náttúruminjar og menningararf aðgengilegri fyrir almenning. Frá sjónarmiði atvinnulífsins er friðað umhverfi oft sérlega aðlaðandi. Með stefnumótun, áætlunum og tilskipunum er í mörgum tilvikum hægt að skapa forsendur fyrir sjálfbæra starfsemi og efla atvinnulíf á og við pau svæði. Jafnframt gerir petta auknar kröfur til peirra aðila sem nýta auðlindina til að láta tekjurnar renna áfram inn í nærsamfélagið og par með í umhverfi sem nýtt er af almenningi. Finna parf aðferðir til að fjármagna sameiginlegan kostnað, t.d. við umhirðu og viðhald á náttúru- og menningarminjum.

Yfirvöld náttúru- og menningarminja í hverju landi ættu, ásamt öðrum opinberum aðilum og starfsgreinasamtökum í atvinnulífinu, að grípa til aðgerða til að auka pekkingu á pýðingu náttúru- og menningarverðmæta fyrir sjálfbæra nýsköpun í atvinnulífinu. Vekja ætti athygli á góðum fordæmum sem geta pannig orðið fyrirmynd og stuðlað að vakningu og lærdómi um störf byggð á grunni náttúru- og menningarminja.

Örva ætti nýsköpunarverkefni sem ná pvert yfir landamæri sveitarfélaga, héraða og ríkja.

\section{... í samspili milli einkageirans og hins opinbera}

Eftirspurn stýrir markaðnum. Pað pýðir að auk sjónarmiða sérfræðinga, sem oft hafa verið ráðandi pegar kemur að meðferð málefna tengdum náttúru og menningararfi, parf að huga að vinnulagi sem snýst um notendur og viðskiptavini. Jafnframt er pörf á að efla pau tæki sem gera markaðnum kleift að styðja sjálfbæra próun.

Bindandi samningar og samstarf milli atvinnulífs, stjórnvalda, rannsóknargeirans og áhugafólks geta veitt aðilum gagnkvæman ávinning. Yfirvöld náttúru- og menningarminja ættu ásamt öðrum stjórnvöldum að íhuga að bindast slíku samstarfi í pví augnamiði að próa byggð, áfangastaði ferðamanna og atvinnulíf. 
Verslunarstarfsemi parf oft að skila fjárfestingum sínum tiltölulega hratt, á meðan opinberir aðilar eiga möguleika á að vinna út frá langtímasjónarmiðum. Jafnframt er ljóst að starfsemi sem leitar eftir hagnaði verður að skila arði til að vera sjálfbær til langframa. Lykilpættir til árangurs eru til dæmis góður markaðsskilningur, virkt samspil við nærsamfélagið og sjálfbær nýting náttúru- og menningarminja. Að auki ættu verkefni á vegum ríkisins að hafa lengri tímaramma en bann sem yfirleitt er notaður í dag pannig að tilætlaður árangur náist. Stjórnvöld ættu að leggja sig fram um að bæta reglugerðir og draga úr stjórnsýslukostnaði fyrirtækja sem reka starfsemi sem byggir á grunni náttúru- og menningarminja.

\section{Mótið góða stefnu um sjálfbæra ferðapjónustu...}

Góð stefnumótun, meginreglur og gæðakerfi fyrir sjálfbæra ferðabjónustu hafa mikil áhrif á pað hvernig starfsemi ferðamála kemur til með að próast. Norðurlöndin geta miðlað hvert öðru af reynslu sinni af sjálfbærri ferðapjónustu og hvað hún pýðir í reynd. Yfirvöld ferðamála, náttúruminja og menningararfs ættu að sameinast um ápreifanleg verkefni og próa samstarf sín á milli. Koma pyrfti á vottunarkerfi, jafnt fyrir áfangastaði ferðamanna og starfsemi innan ferðapjónustunnar. Kerfið pyrfti að sýna samspil á milli umhverfis, efnahagslífs og samfélagslegra pátta. Ef rétt er að farið getur vottun verið tæki til að aðlaga ferðapjónustu í átt að sjálfbæru samfélagi.

\section{... og samhæfið próun ferðamannastaða og byggðapróun}

próun ferðamannastaða parf að vera samstíga sjálfbærri próun í héraði. Mikilvægt er að ferðabjónustan taki mið af forsendum staðarins. Reynslan hefur sýnt að fjárfestingar í stórum ferðapjónustufyrirtækjum geta jafnvel haft jákvæð áhrif á smáfyrirtæki á ferðamannastöðum. Svo að tryggt sé að náttúra og menningararfur verði varanlegir pættir í próun ferðapjónustu og styrki hana, er mikilvægt að litið sé á pá bæði sem auðlind og afurð.

Sjálfbær ferðapjónusta getur gefið samkeppnisforskot í baráttunni um viðskiptavinina gagnvart öðrum ferðamannastöðum. En petta krefst pekkingar. Ferðapjónustan parf að gera sér grein fyrir pví hvað parf til og sjá til pess að verðmæti sem felast í náttúrunni og menningararfinum geti haldið áfram að vera auðlind fyrir atvinnugreinina. Yfirvöld náttúruog menningarminja purfa á hinn bóginn að setja sig í spor og skilja kröfur atvinnulífsins um markaðsaðlögun og arðsemi. Fjarlægðin milli opinberra stofnana, atvinnulífs og nærsamfélags parf að minnka til pess að samvinna verði skilvirk og niðurstöður jákvæðar.

Til að vekja áhuga og dýpka upplifun gesta verða upplýsingar, leið̋sögn og ekki síst gestrisni sífellt mikilvægari. Til að uppfylla væntingar og óskir gesta parf að leggja áherslu á, og endurmeta reglulega, menntun starfsmanna, aðferðir og leiðbeiningar sem lúta að náttúruminjum og menningararfi í heimabyggð. 


\section{Ræðið saman um náttúru og menningararf}

Ekki má vanmeta mikilvægi pess að móta stefnu í miðlun og samskiptum til að auka pekkingu á náttúru- og menningarminjum. Betri aðlögun og samhæfing rafrænnar pjónustu hinna ýmsu yfirvalda getur stuðlað að pví að upplýsingaöflun og miðlun verði skipulegri og nýtist markhópum betur.

Tæknin býður upp á nýja samskiptamöguleika. Auðvelt er orðið að ná til einstakra ferðamanna um netið, farsíma og fleiri tegundir fjarskiptabúnaðar. Einnig eru til mörg dæmi um gagnvirk rafræn tól til að virkja pekkingu heimamanna á umhverfi sínu og greina frá sögnum og minnum um sérstaka staði.

\section{Rannsakið, greinið og fylgið próuninni}

Pörf er fyrir pvervísindalegar rannsóknir á nýtingu náttúru- og menningarminja við sjálfbæra nýsköpun og próun. Meðal annars parf að skoða hugmyndir um mörk náttúru, menningararfs og atvinnulífs. Stjórnvöld í hverju landi fyrir sig ættu að láta taka saman yfirlit um hvaða rannsóknir hafi verið framkvæmdar á pessu sviði, hver árangurinn hafi verið og hvaða pörf sé fyrir hendi á frekari rannsóknum. Í framhaldinu færi fram vinna við stefnumótun um nýtingu náttúru- og menningarminja.

Mikilvægt er að átta sig á tískusveiflum, stöðu og áhrifum út frá öllum víddum sjálfbærni. Ekki er hægt að meta öll verðmæti með efnahagslegum hugtökum en pau hafa samt efnahagslega pýðingu, bæði til lengri og skemmri tíma. Pess vegna verður að halda áfram að próa og uppfæra vísa sem halda utan um verðmæti auðlindarinnar og pýðingu peirra.

\section{Tillaga um áframhaldandi norræna samvinnu}

Petta samstarfsverkefni gerir eftirfarandi tillögur að nýjum norrænum samstarfsverkefnum:

- Skipst á reynslu og greining hagnýtra aðferða og samvinnulíkana milli norrænna landssvæða (svæðabundin/nærsamfélög/sveitarfélög) sem vinna með náttúru og menningararf sem framtíðarúrræði fyrir bróun og nýsköpun. Lagt er til að á völdum svæðum verði haldnar norrænar málstofur til að ræða mikilvæg samfélagsmálefni sem tengjast náttúruog menningarminjum sem framtíðarúrræði ásamt pví að greina „bestu aðferð“ (best practice) fyrir samræmd ríkisafskipti í próunarferli samfélaga eða byggðapróun

- Verkefni sem beinist að pví að útfæra sameiginlegar norrænar meginreglur fyrir sjálfbæra ferðapjónustu

- Fara yfir rannsóknir og aðferðir við mat á hagrænu gildi náttúru- og menningarminja og pví næst að prófa sambærilegar aðferðir á Norðurlöndunum 
Nordiska ministerrådet

Ved Stranden 18

DK-1061 København K

www.norden.org

\section{Aktivera natur och kulturarv \\ - för hållbar utveckling och tillväxt}

Hur kan natur och kulturarv aktiveras för hållbar utveckling och tillväxt? Vilka är möjligheterna respektive utmaningarna? Vilka perspektiv, strategier och metoder används i detta arbete och går det att identifiera särskilda framgångsfaktorer? Detta är exempel på frågor som har diskuterats i det nordiska samverkansprojektet Natur och kulturarv som en resurs för hållbar utveckling och tillväxt. Resultat från projektet presenteras i denna rapport. Genom att förmedla erfarenheter och ge rekommendationer och förslag till fortsatt arbete vill projektet förbättra förutsättningarna för att naturens och kulturarvets potential som utvecklingskraft ska tas tillvara.

Rapporten riktar sig till myndigheter och organisationer som praktiskt, akademiskt eller politiskt arbetar med kulturarv och natur samt regional utveckling och tillväxt. 